I N T ER N ATIONAL MONETARY FUND

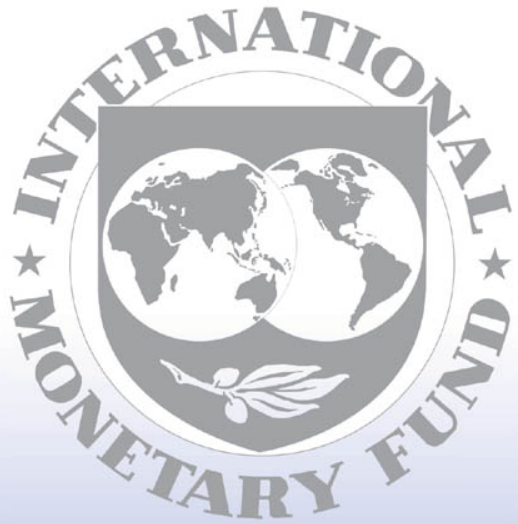

Staff

Country

Reports 


\section{Haiti: Enhanced Initiative for Heavily Indebted Poor Countries- Decision Point Document}

This Enhanced Initiative for Heavily Indebted Poor Countries-Decision Point Document for Haiti was prepared by a staff team of the International Monetary Fund as background documentation for the periodic consultation with the member country. It is based on the information available at the time it was completed on November 7, 2006. The views expressed in this document are those of the staff team and do not necessarily reflect the views of the government of Haiti or the Executive Board of the IMF.

The policy of publication of staff reports and other documents by the IMF allows for the deletion of market-sensitive information.

To assist the IMF in evaluating the publication policy, reader comments are invited and may be sent by e-mail to publicationpolicy@imf.org.

Copies of this report are available to the public from

International Monetary Fund $\bullet$ Publication Services

700 19th Street, N.W. • Washington, D.C. 20431

Telephone: (202) 6237430 • Telefax: (202) 6237201

E-mail: publications@imf.org • Internet: http://www.imf.org

Price: $\$ 18.00$ a copy

\section{International Monetary Fund Washington, D.C.}


This page intentionally left blank 


\section{INTERNATIONAL MONETARY FUND AND \\ INTERNATIONAL DEVELOPMENT ASSOCIATION}

\section{REPUBLIC OF HAITI \\ Enhanced Heavily Indebted Poor Countries (HIPC) Initiative Decision Point Document}

Prepared by the Staffs of the International Monetary Fund and the International Development Association

Approved by Ranjit Teja and Mark Plant (IMF) and

Pamela Cox and Danny Leipziger (IDA)

November 7, 2006

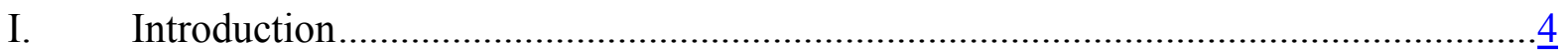

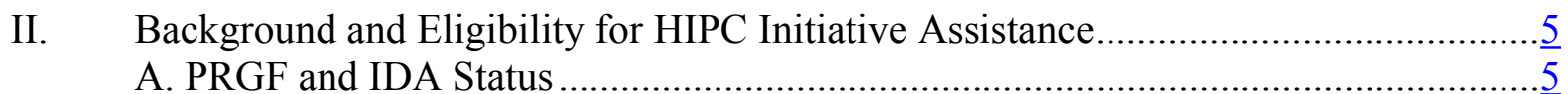

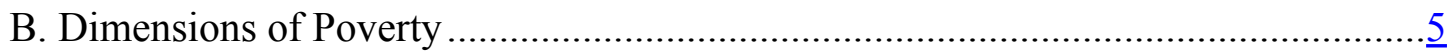

C. Recent Political and Security Developments ..................................................... $\frac{7}{8}$

D. Policy Track Record..................................................................................

III. Macroeconomic Framework and Future reform Agenda....................................13

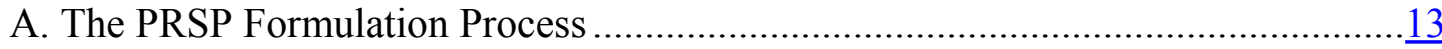

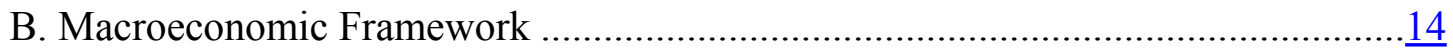

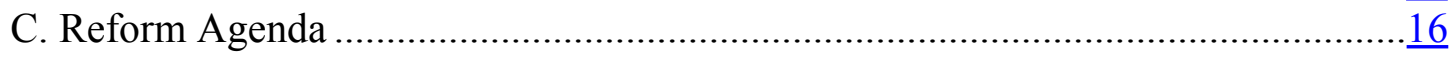

IV. Debt Sustainability Analysis (DSA) and Enhanced HIPC Assistance ......................19

A. Debt Reconciliation Status .................................................................. 19

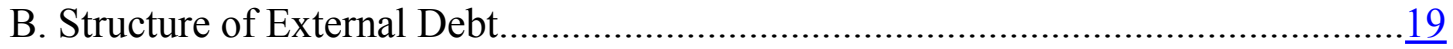

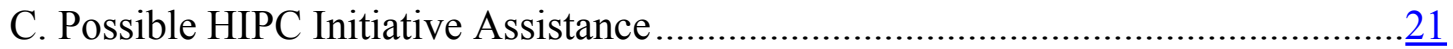

D. Debt Sustainability Analysis ................................................................... $\frac{23}{23}$

E. MDRI and Possible Bilateral Assistance Beyond HIPC .................................. $\frac{23}{25}$

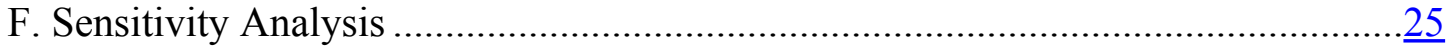

V. The Floating Completion Point......................................................................... 26

A. Triggers for the Floating Completion Point ..............................................

B. Monitoring the Floating Completion Point Triggers....................................... $\frac{26}{28}$

C. The Use and Monitoring of Enhanced HIPC Initiative Assistance....................... $\frac{28}{29}$

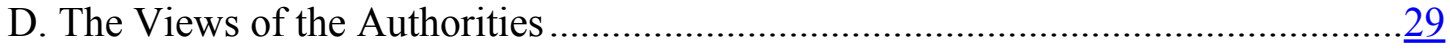


VI. Issues for Discussion.

Text Tables

1. Selected Poverty and Social Indicators

2. Selected Economic and Financial Indicators .

3. External Debt, end-September 2005

Figures

1a. Composition of Stock of External Debt at end-September 2005 by Creditor Group .... $\underline{31}$

1b. Potential Costs of the HIPC Initiative by Creditor Group ...

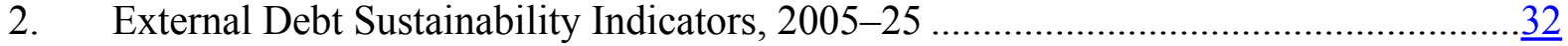

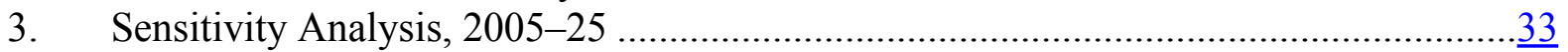

Tables

A1. Nominal Stock and Net Present Value of Debt at end-September 2005 ......................34

A2. HIPC Initiative Assistance Under a Proportional Burden-Sharing Approach................ $\underline{35}$

A3. Discount and Exchange Rate Assumptions ............................................................ $\frac{36}{37}$

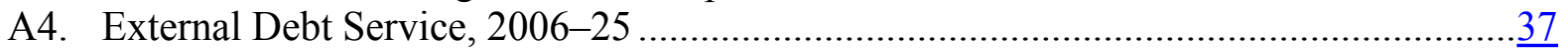

A5. Net Present Value of External Debt, 2005-25 ......................................................... $\frac{38}{39}$

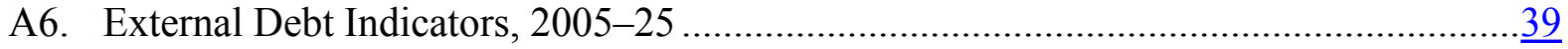

A7. External Debt Indicators and Sensitivity Analysis, 2005-25 …...............................

A8 Enhanced HIPC Initiative: Status of Country Cases Considered under the Initiative, May 2006

A9. Possible Delivery of IMF Assistance under the Enhanced HIPC Initiative ................. $\frac{42}{43}$

A10. Possible Delivery of IDA Assistance under the Enhanced HIPC Initiative ................. 43

A11. Long-Term Macroeconomic Assumptions, 2005-25 ............................................ 44

A12. Paris Club Creditors' Delivery of Debt Relief Under Bilateral Initiatives Beyond HIPC Initiative

Boxes

1. Key Macroeconomic Assumptions Underlying the DSA …...........................................24

2. Triggers for the Floating Completion Point................................................................ $\frac{27}{29}$

3. Expenditure Priorities for the Use of Enhanced HIPC Assistance .................................29

Appendixes

I. Governance Actions and Policies .$\underline{46}$

II. Haiti: Joint Bank-Fund Debt Sustainability Analysis .............................................. $\frac{47}{58}$

III. Debt Management Capacity...................................................................... $\frac{58}{\ldots}$ 


\section{Abbreviations and Acronyms}

\begin{tabular}{|c|c|}
\hline AAP & Assessment and Action Plan \\
\hline AIDS & Acquired Immune Deficiency Syndrome \\
\hline APN & Ports Authority \\
\hline ASYCUDA & Automated System for Customs Data \\
\hline $\mathrm{BRH}$ & Banque de la République d'Haïti (Central Bank of Haiti) \\
\hline CAMEP & Water Authority \\
\hline CEM & Country Economic Memorandum \\
\hline CNIMP & Interim National Commission for Public Procurement \\
\hline CPI & Consumer Price Index \\
\hline CSCCA & Supreme Audit Institution \\
\hline DSA & Debt Sustainability Analysis \\
\hline DHS & Demographic and Health Survey \\
\hline DMFAS & Debt Management Financial Analysis System \\
\hline GDP & Gross Domestic Product \\
\hline GNI & Gross National Income \\
\hline EDH & Electricity Utility \\
\hline EPCA & Emergency Post-Conflict Assistance \\
\hline EGRO & Economic Governance Reform Operation \\
\hline EGTAG & Economic Governance Technical Assistance Grant \\
\hline FER & Road Maintenance Fund \\
\hline HIPC & Heavily Indebted Poor Countries \\
\hline HIV & Human Immune-deficiency Virus \\
\hline IBRD & International Bank for Reconstruction and Development \\
\hline ICF & Interim Cooperation Framework \\
\hline IDA & International Development Association \\
\hline IDB & Inter-American Development Bank \\
\hline IMF & International Monetary Fund \\
\hline I-PRSP & Interim Poverty Reduction Strategy Paper \\
\hline JSAN & Joint Staff Advisory Note \\
\hline LIC & Low Income Countries \\
\hline MDB & Multilateral Development Bank \\
\hline MDG & Millennium Development Goal \\
\hline MDRI & Multilateral Debt Relief Initiative \\
\hline MEF & Ministry of Economy and Finance \\
\hline MENJS & Ministry of Education, Youth and Sports \\
\hline MINUSTAH & United Nations Stabilization Mission in Haiti \\
\hline MSPP & Ministry of Health \\
\hline NEPO & National Education Partnership Office \\
\hline NETP & National Education and Training plan \\
\hline NFP & National Partnership Fund \\
\hline NSPRHS & National Strategic Plan for the Reform of the Health Sector \\
\hline NPV & Net Present value \\
\hline NIR & Net International Reserves \\
\hline OPEC & Organization of Petroleum Exporting Countries \\
\hline PEM & Public Expenditure Management \\
\hline PRGF & Poverty Reduction and Growth Facility \\
\hline PRSP & Poverty Reduction Strategy Paper \\
\hline SDR & Special Drawing Rights \\
\hline SMP & Staff Monitored Program \\
\hline SYSDEP & Automated System for Budget Management \\
\hline TELECO & Telecoms Utility \\
\hline ULCC & Anti-Corruption Unit \\
\hline UNDP & United Nations Development Programme \\
\hline UNAIDS & United Nations Programme on HIV/AIDS \\
\hline UNCTAD & United Nations Conference on Trade and Development \\
\hline
\end{tabular}




\section{INTRODUCTION}

1. This paper presents an assessment of Haiti's qualification for assistance under the Enhanced Heavily Indebted Poor Countries (HIPC) Initiative. ${ }^{1}$ The Executive Boards of the IMF and IDA discussed the Preliminary HIPC document for Haiti on September 6 and 7,2006 , respectively. ${ }^{2}$ On these occasions, Directors made a preliminary determination that Haiti could qualify for assistance under the HIPC Initiative in view of (i) its status as a PRGF-eligible and IDA-only country; (ii) its NPV of debt-to-exports ratio, which is above the indicative threshold of the HIPC Initiative even after the application of traditional debt relief mechanisms; and (iii) satisfactory performance under the two comprehensive Emergency Post-Conflict Assistance (EPCA) programs (October 2004-September 2006) and the IDA-supported EGRO I (since January 2005), with important achievements in the areas of macroeconomic stabilization and structural reforms. ${ }^{34}$ Directors also agreed that Haiti could reach its Decision Point before end-2006, together with the approval of a Poverty Reduction and Growth Facility (PRGF) arrangement by the IMF Board, provided that (i) the country remains on track with its macroeconomic program, supported by the EPCA; (ii) an agreement is reached on appropriate completion point triggers; and (iii) the Interim Poverty Reduction Strategy Paper (I-PRSP) is finalized. Directors supported the possible triggers and key policy measures outlined in the preliminary document.

\section{Haiti's NPV of debt-to-exports ratio as of end-September 2005, after full} application of traditional debt relief mechanisms, is estimated at 176.7 percent and is above the HIPC Initiative threshold. Possible HIPC debt relief is estimated to be US\$140.3 million in end-September 2005 NPV terms (a common reduction factor of 15.1 percent) and relief associated with the Multilateral Debt Relief Initiative (MDRI), also in NPV terms, is estimated at about US\$243 million. ${ }^{5}$ Debt relief under the HIPC Initiative and the MDRI would help Haiti accelerate progress towards the Millennium Development Goals (MDGs).

\footnotetext{
${ }^{1}$ The Enhanced HIPC Initiative will hereafter be referred to as the HIPC Initiative.

${ }^{2}$ See Country Report No. 06/338, August 17, 2006, and IDA Report No 36917, August 15, 2006.

${ }^{3}$ Haiti was included in the list of countries meeting the HIPC Initiative's income and indebtedness eligibility criteria. See "Heavily Indebted Poor Countries (HIPC) Initiative - List of Ring-Fenced Countries that Meet the Income and Indebtedness Criteria at end-2004", IMF Country Report No. 06/348, April 11, 2006, and IDA: R2006-0041/2, April 12, 2006.

${ }^{4}$ Although the two-year track record is relatively short, the HIPC framework has sufficient flexibility to accommodate Haiti's circumstances, including with regard to the length of track record to decision point. See "Assistance to Post-Conflict Countries and the HIPC Framework", Development Committee DC2001-0014, April 20, 2001.

${ }^{5}$ MDRI debt relief from IDA is expected to be US\$243 million in NPV terms. Haiti is not expected to have any eligible IMF debt for MDRI relief.
} 
3. This paper is organized as follows. Section II provides background information on Haiti's eligibility for assistance under the HIPC Initiative; the nature and extent of poverty; recent political and security developments; and the policy track record. Section III discusses the medium-to-long-term macroeconomic framework and the future reform agenda for poverty reduction. Section IV summarizes the results of the Debt Sustainability Analysis (DSA) and presents possible HIPC and MDRI assistance. Section V discusses the floating completion point triggers, specifies how HIPC Initiative assistance after the decision point will be used and tracked, and reports the views of the authorities. Finally, section VI presents issues for discussion by the Executive Directors.

\section{BACKGROUND AND ELIGIBILITY FOR HIPC INITIATIVE ASSISTANCE}

\section{A. PRGF and IDA Status}

4. Haiti is currently an IDA-only country, with a nominal per capita GNI of about US\$450 in 2005 (using the World Bank's Atlas methodology). A PRGF arrangement is scheduled to be discussed by the IMF Board in parallel with this document. ${ }^{6}$ Haiti will continue to need substantial concessional assistance from the international community and is likely to remain an IDA-only country and eligible for PRGF resources for the foreseeable future.

\section{B. Dimensions of Poverty}

5. Political and economic instability, recurrent deterioration in security, low growth, and high inequality and poverty have been the key challenges confronting Haiti in the past. The impact of prolonged political conflicts and violence, periods of high external assistance followed by the withdrawal of economic support, and natural disasters has been severe. Real income per capita has declined on average by 2 percent annually over the past twenty years. Haiti's pattern of socio-economic development has been characterized by marked inequalities in access to productive assets and public services, which, together with low growth, has resulted in widespread poverty.

6. Haiti is the poorest country in the Latin America and Caribbean region and amongst the poorest in the world. The 2005 United Nations Human Development Index ranked Haiti 153rd out of 177 countries. About 54 percent of Haiti's population lives below

\footnotetext{
${ }^{6}$ In October 2005, the Executive Board of the IMF approved SDR10.25 million (about US\$14.7 million) in Emergency Post-Conflict Assistance (EPCA) to Haiti, adding to the SDR10.23 million (about US\$15.6 million) provided under the EPCA in January 2005. When approving the EPCA, IMF Directors indicated their support for a rapid transition to a program supported by the PRGF.
} 
the US\$1 a day poverty line and 78 percent below US\$2 a day (2001 data). ${ }^{7}$ An overwhelming share of the rural population lives in poverty. ${ }^{8}$ There are also large pockets of urban poverty in slum areas in Port-au-Prince, although many small cities and municipalities have lower poverty rates. Wide disparities exist regionally, with poverty being lowest in the Ouest region (34 percent), which includes the capital Port-au-Prince, and highest in the NordEst region (81 percent). Nonetheless, even in the Ouest region poverty is extremely high by international standards (higher than that of any country in Latin America and the Caribbean). Income inequality in Haiti is also high. Nearly half of national income goes to the richest 10 percent of the population. ${ }^{9}$

7. On social indicators Haiti ranks very low. Although adult illiteracy decreased from 60 percent in 1990 to 52 percent in 2003, it remains the highest in the Latin America and the Caribbean region and is higher than the average for low-income countries. Only 55 percent of children aged 6-12 are enrolled in school; in rural areas this indicator is even lower at 23 percent. Food deprivation and limited access to health care, due to poor infrastructure and lack of qualified personnel and drugs, have resulted in dire health conditions for Haiti's poor. Haiti also faces a high incidence of HIV/AIDS. UNAIDS estimates that 5.6 percent of the adult population has HIV. Despite all the risk factors in Haiti, there is some evidence that HIV/AIDS prevalence rates have not increased significantly in the last decade and may even have declined. UNAIDS credits this positive trend to close public-civil collaboration and sustained political commitment to contain the disease.

\footnotetext{
${ }^{7}$ Although based on the Enquête sur les Conditions de Vie en Haiti (ECVH) 2001, used for the estimation of poverty indicators included in this document, some poverty indicators included in the I-PRSP differ slightly from the figures presented above, due to differences in the methodology used.

${ }^{8}$ Incidence of poverty in rural areas is 69 percent for the US\$1 a day poverty line and 86 percent for the US\$2 a day poverty line.

${ }^{9}$ Estimates based on household surveys suggest that poverty and inequality rates may have not changed substantially over the last two decades. Part of the explanation could be that, while GDP per capita declined, consumption levels were maintained by remittances which have accelerated since the mid-1990s.
} 
Table 1. Haiti: Selected Poverty and Social Indicators

\begin{tabular}{|c|c|c|c|}
\hline & Haiti & $\mathrm{LAC} 1 /$ & LIC 2/ \\
\hline Population (million, 2002) (3/ $^{3 /}$ & 8.3 & 540 & 2,615 \\
\hline Of which rural (percent) & 62.5 & 23.3 & 69.8 \\
\hline Annual population Growth (2003-15) & 1.4 & 1.3 & 1.6 \\
\hline Life expectancy at birth (Years, 2003) ${ }^{3}$ & 51.6 & 71.9 & 58.4 \\
\hline GNI per capita (2005 for Haiti, 2004 for LAC and LIC) ${ }^{4 /}$ & 450 & 3,576 & 507 \\
\hline $\begin{array}{l}\text { Incidence of Poverty (percent of the population below the US\$1 a day poverty } \\
\text { line, } 2001 \text { data for Haiti; } 202 \text { data for LAC) }{ }^{5}\end{array}$ & 53.9 & 8.9 & .. \\
\hline Adult literacy ratio ( percent of people age 15 and above, 2003) $3 /$ & 51.9 & 89.6 & 60.8 \\
\hline Primary school net enrollment ratio (percent of relevant age group, 2001) ${ }^{6}$ & 55 & .. & .. \\
\hline Infant mortality rate (per thousand, 2003) & 76 & 27 & 80 \\
\hline Child mortality rate (per thousand, 2002) & 118 & 32 & 124 \\
\hline Maternal mortality rate (per 100,000 live births, 2000$)^{5 /}$ & 680 & 194 & 682 \\
\hline Access to improved water source (percent of population, 2002) (3/ $^{3 /}$ & 71 & 89 & 77 \\
\hline Prevalence of HIV/AIDS (percent of persons age $15-49,2003)^{3 /}$ & 5.6 & 0.7 & 2 \\
\hline
\end{tabular}

1/ Latin American and the Caribbean region.

2/ Low-Income Countries.

3/ UNDP, Human Development Report 2005.

4/ World Bank, 2006 World Development Indicators (for LAC and LIC). World Bank, staff estimates (for Haiti). Calculated using the

World Bank Atlas method.

5/ World Bank, 2006 World Development Indicators.

6/ World Bank, staff estimates based on the ECVH 2001 data.

8. Given the significant gaps in development indicators, Haiti is unlikely to achieve all its Millennium Development Goals (MDGs) by 2015. Public sector contribution to the provision of basic social services has been very limited and, as a result, the majority of the Haitian population does not have access to these services. For instance, 90 percent of primary schools are non-public and charge fees that represent, on average, 20 percent of the incomes of the poorest quintile, thus barring access to many families. Quality is also a problem, 70 percent of schools lack accreditation and 60 percent of teachers are unqualified. As with education, health services are predominantly provided by non-public institutions (70 percent) and the quality is generally poor. Overall, only 28 percent of the population has access to health facilities. Similarly, most of the clean water and sanitation services are non-publicly provided. Despite the predominant role of the private sector in the provision of basic social services, the normative and regulatory role of the Government is weak. The Government plans to introduce measures to address immediate social problems while developing and implementing strategies to help Haiti make progress towards reaching the MDGs. With continued external financial assistance (including HIPC and MDRI relief) Haiti could reach some MDGs, notably goal 2 (achieve universal primary education) and goal 7 (combat HIV/AIDS, malaria and other diseases), and make progress towards reaching the others.

\section{Recent Political and Security Developments}

\section{Following the insurrection that quickly evolved into a widespread violent conflict} in early 2004, President Aristide resigned and left the country. The political crisis that followed was halted with the establishment of a Transition Government mandated to organize elections and undertake measures in the areas of security, development, and creating 
the ground for a new national dialogue. The Political Transition Agreement established the political framework in which the Transition Government operated. To address the high instability and violence that prevailed, the United Nations Security Council authorized the deployment of a Multinational Interim Force, later replaced by the United Nations Stabilization Mission in Haiti (MINUSTAH). The mandate of the forces was to help the Transition Government reestablish the security and stability required for the advancement of the constitutional and political process in the country. While security has improved since 2004, outbursts of violence are still occurring.

\section{The recent successful presidential and parliamentary elections provide an} opportunity to overcome the legacy of past decades. A coalition Government has been formed, including ministers from different political parties. The coalition Government received almost unanimous approval in Parliament, raising hopes for moving forward with an ambitious agenda to improve access and quality of basic social services, modernize the state, pursue and deepen governance reform, wage a war against corruption, and promote private sector investment.

11. The security situation remains fragile, especially in the capital, Port-au-Prince. The July 2006 International Conference for Haiti's Economic and Social Development underlined the need for a coordinated and rigorous action from all partners to reestablish a climate of security, which is indispensable to achieve social and economic objectives. President Préval has shown a determination to reach out to all political and social forces in Haiti in a spirit of reconciliation and dialogue. Also, recently the Government launched a disarmament and community reinsertion program for armed groups and intends to pursue ongoing efforts to reform the police and the judiciary.

\section{Policy Track Record}

\section{Since mid-2004, Haiti's economic and social recovery and its structural reforms} have been supported by donors under the Interim Cooperation Framework (ICF). The ICF, presented by the Transition Government at the July 2004 donors' conference in Washington, D.C., provided an interim framework until an elected Government was in place. The ICF framework was extended by the current Government to September 2007 at the July 2006 conference. ${ }^{10}$ The initial macroeconomic framework was established under the Fund's staff-monitored program (SMP) covering the period April-September 2004. Over the following two years, the authorities' macroeconomic program has been supported by the IMF's EPCA, with disbursements in January and October 2005 (US\$30.3 million). Following the clearance of arrears to IDA (US\$52.3 million) in early 2005, the Government also received support from IDA to implement economic governance reforms (through an Economic Governance Reform Operation, EGRO, of US\$61.0 million, and two Economic Governance Technical Assistance grants of US\$2.0 million each) and to support the

\footnotetext{
${ }^{10}$ At the conference, donors pledged about US\$750 million for the period July 2006-September 2007.
} 
country's recovery through community driven interventions, disaster prevention and management activities, transport and territorial development programs and electricity. The Inter-American Development Bank (IDB), the European Union (EU) and bilateral donors have also provided significant financial and technical assistance.

\section{During 2004-06, Haiti made significant progress toward strengthening} macroeconomic stability (see Table 2 ). The economy has gradually recovered from the political turmoil and severe floods experienced in 2004 and annual GDP growth is expected to increase to 2.5 percent in FY2006 from 1.8 percent in FY2005. ${ }^{11}$ However, security problems have adversely affected economic activity, donor project implementation and other inflows of foreign exchange. With increased revenues and tighter expenditure controls, the central Government overall deficit (including grants) was reduced from 3.5 percent of GDP in FY2003 to 1.4 percent in FY2006. This has largely eliminated recourse to central bank financing of the central Government deficit. This substantial fiscal adjustment has also helped reduce end-of-period inflation from 37.8 percent in FY2003 to 12.4 percent in FY2006; however this rate of inflation is still high relative to comparable low income countries. Net international reserves (NIR) have increased, raising import coverage from $1 \frac{1}{4}$ months of imports of goods and services in FY2003 to an estimated 1.8 months in FY2006. The authorities' program supported by the EPCA remains on track, and preliminary data indicate that key end-September 2006 quantitative targets have been met.

Table 2. Haiti: Selected Economic and Financial Indicators

(Fiscal year ending September 30)

\begin{tabular}{|c|c|c|c|c|}
\hline & 2003 & 2004 & 2005 & $\frac{2006}{\text { Prel. }}$ \\
\hline \multicolumn{5}{|c|}{ (Annual percentage change, unless otherwise indicated) } \\
\hline GDP at constant prices & 0.4 & -3.5 & 1.8 & 2.5 \\
\hline Real GDP per capita & -1.7 & -5.4 & -0.2 & 0.8 \\
\hline Consumer prices (end-of-period) & 37.8 & 21.7 & 14.8 & 12.4 \\
\hline \multicolumn{5}{|c|}{ (In percent of GDP) } \\
\hline Central government overall balance (including grants) & -3.5 & -2.4 & -0.7 & -1.4 \\
\hline \multicolumn{5}{|c|}{ (Changes in percent of beginning-of-period broad money) } \\
\hline Broad money (including foreign currency deposits) & 39.8 & 9.1 & 20.3 & 9.1 \\
\hline \multicolumn{5}{|c|}{ (Annual percentage change, unless otherwise indicated) } \\
\hline Net international reserves (in millions of U.S. dollars) 1/ & 38.8 & 54.5 & 70.6 & 125.7 \\
\hline Liquid gross reserves (in millions of U.S. dollars) 2/ & 157.1 & 207.4 & 228.5 & 330.8 \\
\hline In months of imports of the following year & 1.2 & 1.4 & 1.4 & 1.8 \\
\hline
\end{tabular}

Sources: Ministry of Economy and Finance; Bank of the Republic of Haiti; and Fund staff estimates.

1/ Excludes commercial banks' foreign currency deposits with the BRH.

2/ Gross reserves excluding capital contributions to international organizations.

${ }^{11}$ The Haitian fiscal year runs from October 1 to September 30. 


\section{Progress has also been achieved in the implementation of structural and economic} governance measures, notably under the EPCA and EGRO. As of early 2004, Haiti was confronted with significant weaknesses in economic governance and management, which impeded the efficient use of both domestic resources and external financing. ${ }^{12}$ The main weaknesses were in the following areas: (i) budget formulation, execution and reporting; (ii) public procurement; (iii) public enterprise management and road maintenance;

(iv) human resource management; and (v) the financial sector. Progress in these areas are as follows:

- Budget formulation, execution and reporting. Prior to 2004, the Government had at times operated without approved budgets or with budgets approved late into the fiscal year. Procedures for budget formulation and execution were weak and a significant share of public resources was channeled through multiple comptes courants held by individual ministries and used non-transparently. ${ }^{13}$ In addition, internal controls were impaired by the lack of a well-structured accounting system or external audits of Government budgets. Recent Government measures to address these weaknesses include: (i) passage of a new Organic Budget Law ${ }^{14}$ and adoption of a new budget classification and chart of accounts; (ii) approval of the budgets for FY2005 and FY2006 before the start of the fiscal year and regular public dissemination of key budget allocations and execution information; (iii) preparation of the FY2006 budget according to the new budget classification and expansion of the automated system for budget management (SYSDEP) from 5 ministries and units to $17 ;^{15}$ (iv) a drastic reduction of discretionary spending through ministerial comptes courants $;{ }^{16}$ and (v) strengthening the external audit function with a decree on the organization and functioning of the supreme audit institution, the Cour Supérieure des Comptes et Du Contentieux Administrative (CSCCA). The CSCCA is in the process of catching up on Government accounts audits which, together with the resumption of Parliament oversight functions, will strengthen external controls. Other measures have proceeded more slowly: (i) a mechanism for monitoring budgetary transfers to the electricity sector has been established but is not yet effective and an

\footnotetext{
${ }^{12}$ Reflecting these weaknesses, Transparency International's Corruption Perception Index (as well as other governance indices) has placed Haiti among the lowest rankings worldwide and has identified corruption as one of the leading constraint on economic growth and investment. See "La Fondation Héritage pour Haïti", L'Etat des Lieux de la Corruption en Haïti, 2003.

13 The "comptes courants" (Ministries' accounts) were originally meant to be used for unforeseen or nonbudgeted needs such as for assistance to those affected by a natural disaster or unexpected travel by policy makers.

14 The Law mandates the creation of a new accounting system, creates the position of internal ex-ante controllers and a new internal auditing office.

15 The expansion of the SYSDEP is being undertaken in two phases. The first phase, already completed, includes key ministries and units such as the MEF, the CSCCA, the ministries of Education (MENJS) and Health (MSPP), and the Tax and Customs Directorates. The second phase, including all remaining ministries and the National Police, is scheduled to be completed in late 2006.

${ }^{16}$ The percentage of non-salary current public expenditures disbursed through comptes courants was reduced from 62 percent during October 2003-March 2004 to less than 10 percent in FY2005-06.
} 
independent audit of the transfers has not taken place; and (ii) a survey of domestic payment arrears of the central Government has been completed but not yet fully verified and a strategy to address them has not been formulated.

- In the early 2000s, public procurement operated under a 1989 decree which had not been fully implemented and had several flaws, and sole-source contracts and unadvertised bidding were the norm. Since 2004, the institutional framework for public procurement has been strengthened through: (i) the passage of a new Procurement Decree and the creation of the National Commission for Public Procurement (CNMP) in 2004; (ii) the preparation of standard bidding documents; and (iii) the publication of lists of Government contracts and of a supplier database. The recent hiring of an international procurement consulting firm will help the CNMP to strengthen procurement capacity in line ministries.

- In 2004 an Anti-Corruption Unit (ULCC) was created and staffed as an autonomous entity under the Ministry of Economy and Finance (MEF). The Unit is conducting a comprehensive diagnostic survey of the state of governance and the perception of corruption in Haiti as an input to the design of a national anti-corruption strategy and has prepared a draft law for public sector employees' asset declaration. ${ }^{17}$

- Public enterprises have been characterized by inadequate financial and operating practices and a lack of managerial accountability, often accompanied by the siphoning of budgetary resources. Due to the limited resources for maintenance and investment, the quality and reliability of services provided by these enterprises deteriorated over the years. Poor governance practices were particularly acute in the electricity (EDH) and telecoms (TELECO) utilities, and the port authority (APN), which are critical for economic growth. In 2006, financial audits of APN, TELECO and EDH and an accounting rehabilitation of TELECO and EDH were completed. In 2005-06, the Government took a number of measures to strengthen the Road Maintenance Fund (FER), created in 2003 as the cornerstone of Haiti's road maintenance strategy. The FER now has reached a basic level of institutional capacity with the recruiting of key staff and the definition of its operational procedures.

- In the area of public expenditure management (PEM), an Assessment and Action Plan (AAP) to strengthen the capacity of Haiti to track poverty reducing public spending was prepared jointly by IDA and IMF staffs in consultation with the authorities in June 2006. Compared to an informal assessment undertaken in 2004, the 2006 AAP confirms that improvements in PEM performance resulting from the above reforms. ${ }^{18}$ The reforms started from a very low base of economic governance and focused

\footnotetext{
17 The diagnostic survey was completed in March 2006. The final report is expected to be completed by end 2006.

${ }^{18}$ An informal assessment was undertaken in September 2004 by the IMF staff.
} 
on critical institutional and legal changes related to public expenditure and public enterprise management. These efforts will require follow-up actions and additional reforms to ensure that (i) procedures and practices are consistent with the revised legal and institutional framework; (ii) mechanisms to better target public resources are set up; (iii) the quality of monthly fiscal data is improved; and (iv) citizens are empowered in ways that will improve public sector transparency and accountability. In this respect, governance measures aimed at making public service delivery more responsive and effective and improving the comprehensiveness of the budget are needed to increase the effectiveness and transparency of public resource use.

- In 2005 the Government introduced a mechanism for civil society to monitor its program of economic governance reforms. This mechanism became operational in early 2006, following capacity building by both the Government and civil society organizations. A summary of the monitoring reports prepared by civil society organizations has been published on the MEF website. A workshop with the Government relevant agencies and ministries and civil society organizations was held in June 2006 to review the experience in implementing the monitoring mechanism and identify measures to improve its effectiveness.

- The inadequate quality and quantity of human resources have been an impediment to public sector efficiency in Haiti. This results from the scarcity of skilled people and the lack of an adequate incentive and accountability system to attract, maintain and motivate civil servants. Public sector employment in Haiti is very small by international standards. In 2004, public sector employment corresponded to 0.7 percent of the population, compared with 2.0 percent in Africa and 7.7 percent among developed market economies. ${ }^{19}$ Dealing with these shortfalls in a manner that supports sustained public sector efficiency will likely require increasing the efficiency of the use of scarce human resources and implementing reforms involving systemic restructuring of the civil service. In 2004, a new Civil Service Decree was enacted. A Coordination Unit in the Prime Minister's Office has taken on the human resource functions as a first step to overseeing the implementation of the Decree and a census of employment in selected ministries has been completed.

- Financial sector stability has been maintained, but weaknesses have been identified in the mechanism of monetary management and in financial audit and controls of the Central Bank of Haiti (BRH), and the BRH has experienced operational losses. The authorities are preparing a plan to address these weaknesses, including with technical assistance provided by the IMF. A draft of a new banking law is expected to be finalized and submitted to Parliament later this year. In addition, the financial statements of the BRH for FY 2004 were published, however with a year delay. Financial statements for FY2005 have not yet been published. The BRH was also subject to a safeguards

\footnotetext{
${ }^{19}$ Jaramillo, L. (2005) “Public Sector Employment in Haiti” IMF Selected Issues Paper, (seewww.imf.org).
} 
assessment in relation to drawings under the EPCA and the vulnerabilities identified by that assessment are now being addressed; and the BRH has strengthened its surveillance of credit cooperatives.

15. While significant progress has been made in implementing macroeconomic, structural and governance reforms, setting Haiti on a path of economic recovery will remain a major challenge. Economic recovery will critically require restored security, but a sustained improvement in security will in turn depend on the delivery of quick and visible improvements in the living conditions of the Haitian population. Furthermore, strengthened public institutions and improved economic governance are needed to ensure that economic growth is inclusive and sustained over time. The financial and technical support of the donor community will be critical to help the Government address these challenges. While current conditions in Haiti present significant risks going forward, the provision of HIPC debt relief will contribute to creating fiscal space for much needed poverty-related expenditures and encourage reforms in public expenditure management.

\section{MACROECONOMIC FRAMEWORK AND FUTURE REFORM AGENDA}

\section{A. The PRSP Formulation Process}

16. In September 2006, the Government completed the preparation of the I-PRSP which was initially drafted in late 2005 by the Transition Government and subsequently revised by the current Government to reflect its development priorities. The I-PRSP outlines the main areas of intervention envisaged by the authorities to reduce poverty as well as the steps to be undertaken in the preparation of the full Poverty Reduction Strategy (PRS). ${ }^{20}$ The Government's main development priorities are to consolidate macroeconomic stability, enhance physical infrastructure, expand access to social services, improve economic governance and strengthen public institutions. This program represents a continuation of the axes and the strategic objectives of the $2004 \mathrm{ICF}$, with an increased emphasis on a national development approach including all of Haiti's departments and communes and interventions aimed at meeting pressing social and economic needs in disadvantaged and conflict-prone areas.

17. The Government has begun the preparation of a full PRSP. The participation process will be broadened and deepened in the preparation of the full PRSP. The I-PRSP includes a detailed strategy for the consultations which will include members of Parliament, civil society organizations, affected stakeholders, and the donor community and will target the poor through meetings in communes and departments. The I-PRSP also describes the

\footnotetext{
${ }^{20}$ A joint IDA-IMF Staff Advisory Note on the Interim PRSP, circulated in parallel with the Decision Point document, indicates that the I-PRSP provides an appropriate framework for poverty reduction and use of resources that could become available under the HIPC Initiative.
} 
process through which the mechanism for monitoring and evaluation of the PRSP will be developed.

18. The full PRSP would be expected to build on the I-PRSP by (i) presenting a comprehensive medium and long-term strategy and an agenda for its implementation; (ii) establishing efficient mechanisms and easy-to-monitor indicators for progress, including for the MDGs; (iii) refining the structural reform agenda and providing more detailed and focused sector strategies; (iv) clearly defining priority expenditures within the framework of a strengthened public sector investment program; and (v) identifying interventions to enhance public sector program and project implementation capacity.

\section{B. Macroeconomic Framework ${ }^{21}$}

\section{An important objective of the authorities is to achieve robust and sustainable real}

economic growth. Real output growth is projected to average 4.2 percent over the period FY2006-25. ${ }^{22}$ In the short term, real output growth is projected to strengthen sharply from 1.8 percent in FY2005 to 4.0 percent in FY2007, assuming significant improvements in security conditions, continued strong external support, and increased public investment. Over the long term (FY2015-2025), real output growth is expected to average 4.5 percent. ${ }^{23}$ This projected improvement in real output growth depends critically on maintaining security, sustained political and macroeconomic stability, progress on economic governance, and improvements in social and economic infrastructure, contributing to higher private investment, including FDI.

\section{The authorities are also aiming for low and stable inflation, to foster an} environment conducive to long-term growth. End-of-period inflation has declined from 37.8 percent in FY2003 to an estimated 12.4 percent in FY2006 following substantial fiscal adjustment. Building on recent strengthening of fiscal discipline and change in the conduct of monetary policy, inflation is expected to decline gradually to 5.0 percent by FY2011.

\footnotetext{
${ }^{21}$ The macroeconomic projections used in this analysis cover the next 20 years and were prepared in consultation with the authorities.

${ }^{22}$ This is a more conservative projection compared with the one presented in the HIPC Preliminary Document, which assumed an average annual growth of 4.7 percent. The downward revision to growth reflects two factors. First, the assumption of a more gradual reduction in the binding constraints to growth, preventing Haiti from reaching its long-term growth rate rapidly. In the preliminary document, Haiti was expected to reach its longterm (steady-state) growth in FY2011, compared to FY2015 in the Decision Point document. Second, the updated projection makes a more conservative assessment of Haiti's long-term economic growth potential (which was reduced from 5.0 percent to 4.5 percent for the period FY2015-25).

${ }^{23}$ While real GDP growth has been low during the past half century, this largely reflects the impact of episodes of political instability. Excluding these shocks, Haiti experienced periods of high growth, notably in the 1970s, with average real GDP growth close to 4.5 percent, fueled by investment in light manufacturing (in particular the garment assembly industry) and tourism. This sustained period of high growth serves as a benchmark for Haiti's growth potential, and the long-term projection assumes that Haiti enters a path of restored security. However, the sensitivity analysis detailed in section IV F includes a scenario with lower growth.
} 
21. Macroeconomic stability is also expected to be supported by fiscal prudence. Over the projection period, the central Government overall deficit is expected to average about 2.0 percent of GDP. The Government is expected to increase revenues and seek concessional external financing to allow for increased pro-poor spending, higher investment and the institutional development of central and local Governments, while maintaining debt sustainability after the delivery of HIPC Initiative assistance.

\section{Fiscal revenues are projected to increase gradually to about $\mathbf{1 6 . 0}$ percent of GDP} by FY2025, compared to about 9.6 percent over FY2004-06. The Government intends to implement measures to boost revenues, including through the strengthening of customs control in the provinces, enhanced computerization of tax and customs administration offices, and reinforcing the tax audit mechanism.

23. Government expenditures are expected to be re-oriented toward strengthening the institutional capacity of the Government and increasing spending in key areas such as security, health and education. Rebuilding social and economic infrastructure is expected to be the core of the public investment program which is expected to be financed largely by external donors. The framework assumes that the share of pro-poor spending in overall outlays will increase to assist in poverty reduction and meeting the MDGs.

\section{For the long-term growth projection to materialize, Haiti's level of investment has} to increase markedly, by more than 4.0 percentage points of GDP over the projection horizon. ${ }^{24}$ Initially, higher investment will come from higher public investment, especially in public infrastructure, helping to create the conditions for private sector development. An improvement in security is pivotal to ensure this outcome. As infrastructure constraints are gradually removed, agricultural production and exports are expected to pick up. Improvement in tourism infrastructure would create favorable conditions for the tourism industry which notably caters to the large Haitian diaspora.

25. The external current account deficit (excluding grants) is expected to decline from 7.5 percent of GDP in FY2006 to about 5.2 percent of GDP at the end of the projection period largely due to improvements in net exports. The import-to-GDP ratio is projected to decline by 2.4 percentage points of GDP in the long term due to lower aid flows and increases in local production, e.g., in the agricultural sector. Rising exports (by 2.0 percentage points of GDP) are also expected to contribute to the improvement in the current account. ${ }^{25}$ International reserves are expected to increase from 1.6 months of imports of goods and services in FY2005 to over three months from FY2011.

\footnotetext{
${ }^{24}$ The investment numbers in the macroeconomic framework reflect the reporting in the Haitian national accounts, which may significantly overestimate investment as a share of GDP. Investment was reported at 27.4 percent of GDP in FY2005.

${ }^{25}$ Exports of some agricultural products, such as mango and coffee, are expected to be strong, followed by exports of textiles and apparel industry, which are expected to be less robust given the ongoing changes in the
} 


\section{Reform Agenda}

\section{The reform agenda going forward is reflected in the I-PRSP prepared by the} Government and presented to IDA and the IMF in September 2006. The Government has expressed its commitment to maintaining macroeconomic stability, pursuing and deepening the structural and economic governance reform agenda of the last two years and making significant efforts in fighting corruption. The agenda is strong in cross-cutting governance initiatives which, in addition to strengthening security, are necessary if Haiti is to achieve the high, sustained and shared economic growth that is required to reduce poverty and bring about meaningful change in the living conditions of the Haitian population. ${ }^{26}$

\section{The Government intends to continue to strengthen public expenditure}

management. Specifically, the Government plans to: (i) align public spending with the priorities identified in the I-PRSP and, when completed, the PRSP, reflecting emphasis on pro-poor growth; (ii) introduce a medium term framework which will include budget projections consistent with the PRSP expenditure priorities; (iii) adopt an automated mechanism to track poverty-reducing public expenditure and publicly disseminate quarterly expenditure reports; and (iv) ensure accountability and oversight of its accounts in strict observance of the prevailing legal framework. In addition, the Government intends to strengthen the procurement function, by adopting and implementing a new law in line with international best practice and ensuring compliance by all Government purchasing agencies, and continue to publish Government contracts awarded. The IMF and IDA staffs will assist the authorities in the evaluation of existing systems of public finance management and the identification of additional areas where further reforms and technical assistance are needed. ${ }^{27}$

\section{The Government also plans to improve the management of public enterprises and} road maintenance. The Government will modernize public enterprises to increase their efficiency and maximize their profitability. Particular emphasis will be given to improving governance and transparency. The Government intends to enforce annual audits of key public enterprises in line with the prevailing legal and regulatory framework guiding them and to ensure that key audit recommendations are addressed. In the electricity sector, all Government transfers to the electricity utility (EDH) will be monitored and will be independently verified and a competitive bidding process for petroleum purchases for the sector will be introduced. Also, the Government intends to continue the improvement of the

world market following the phasing out of the Multi-Fiber Agreement. A potential offsetting impact may result from the HOPE Act and possible future joint production arrangements with Dominican Republic producers. Nevertheless, an increase in textile exports or tourism would not lead to a substantial increase in net exports due to their high import components.

${ }^{26}$ Please see Appendix 1 for a summary of governance measures related to participation, accountability and oversight, and transparency included in the Government's reform agenda.

${ }^{27}$ IDA is conducting an integrated Public Expenditure, Financial Accountability and Procurement Assessment. The IMF will provide further technical assistance to improve public financial management. 
institutional capacity of the road maintenance agency (FER) to ensure good management practices, including transparency and accountability of its operations.

29. To increase public sector employees' accountability, the Government intends to adopt and implement a law on asset declaration, including sanctions for non-compliance. In addition, in 2007 the Anti-Corruption Unit (ULCC) will submit for Government approval a multi-sectoral strategy to fight corruption. ${ }^{28}$ The Government also intends to continue to support the ongoing mechanism for civil society to monitor economic governance reforms.

30. Reforms will also focus on improving the monetary policy framework and policy instruments to reduce inflation. Measures and reforms will include the auction mechanism for central bank bonds, recapitalization of the central bank, which will also cease its non-core activities, and submission to Parliament of a new central bank law. Financial statements of the BRH will be subject to annual audits and their results published. The Government also intends to submit a new banking law and issue implementing regulations. Additional measures may be taken in the financial sector following a Financial Sector Assessment to be conducted at the request of the Government by the IMF and IDA in early 2007.

\section{The Government is committed to forcefully implement measures to boost revenue} and fight fraud and tax evasion. In particular, it plans to establish customs control at all ports of entry and borders, reinforce and restructure tax collection agencies, increase the accountability of collection agents, and enhance computerization of tax and customs administration offices. In addition, to reduce the vulnerability of the budget to external shocks, the Government will continue to implement a flexible price-setting mechanism for petroleum prices.

32. Private sector development is key for growth in Haiti. The Government intends to promote the sector by improving security and stability, enhancing infrastructure and protecting property rights, establishing one facilitation center for investors, and over the medium term revising the relevant investment and tax laws. With 62.5 percent of the Haitian population living in rural areas, most of which are poor, increasing agricultural productivity and diversification are amongst the Government's priorities to revitalize the economy and reduce poverty. The actions and reforms that the Government plans to introduce in this sector include: (i) increasing smallholder access to credit and other agricultural inputs:

(ii) rehabilitating agricultural infrastructure; (iii) improving land tenure rights to promote investment in irrigation and storage; and (iv) increasing extension activities and the promotion of new seed varieties.

33. The authorities intend to modernize and strengthen the Central Government. This will involve first determining the number, mission, and function of ministries and autonomous entities and later rationalizing employment and the salary policy in the public sector. Such systemic restructuring of the civil service will help increase the efficiency of the

\footnotetext{
${ }^{28}$ Information from the diagnostic survey referred in footnote 17 will inform the preparation of the strategy.
} 
use of scarce human resources. Over the coming year, the Government plans to update the public sector employee database and ensure its regular use, and define the system, applicability and procedures for new recruitments and promotions based on performance. Decentralization of Government authority and public services, through a medium-term plan requiring significant strengthening of institutional capacity for effective local Government functioning, will help Government services to be closer to the users and promote inclusion and participation of all levels of the population.

\section{The Government's plan for the Education Sector is described in the National} Education and Training Plan (NETP). The NETP, and most recently the I-PRSP, define key actions and reforms required to improve the education system and broaden access, particularly of the poor: (i) increase public resources allocated to education for both improved access and quality; (ii) strengthen the capacity of the Government to fulfill its planning, coordination and normative responsibilities; and (iii) establish the National Education Partnership Office (NEPO) and the National Partnership Fund (NPF). The NEPO is designed to promote policy dialogue and operational coordination between the public and non-public sectors, including supervision and evaluation of non-public schools by the State while the companion NPF would provide a public financing mechanism to help poor families pay for the school fees of their children in non-public schools. This is the first real sector governance structure which encompasses all key education stakeholders, promoting not just effective dialogue between the public and non-public sectors but also accountability and transparency in the use of public education funds, particularly those channeled through the National Partnership Fund. ${ }^{29}$

\section{The Government is preparing a National Strategic Plan for the Reform of the} Health Sector (NSPRHS). The NSPRHS and also the I-PRSP, define as key actions and reforms to increase the access and quality of heath service provision: (i) increase public resources to improve access and quality of health care; (ii) strengthen the capacity of the Government to fulfill its planning, coordination and normative responsibilities; (iii) promote policy dialogue and operational coordination between the public and non-public sectors; (iv) enhance preventive measures, particularly by introducing mass immunization campaigns for infants and school children; (iv) increase the number of health units at the commune level that can provide a minimum service package; (v) expand the availability of essential drugs; and (vi) introduce a transparent and accountable mechanism to provide free access to health services to the poorest Haitians.

\section{The Government plans to prepare a strategy to combat HIV/AIDS in consultation} with civil society and the donor community. The I-PRSP indicates that the strategy will also define the institutional framework needed for the planning, coordination and monitoring of the actions and reforms introduced in the context of the strategy. In parallel, the authorities

\footnotetext{
${ }^{29}$ The NEPO is expected to be governed by an eight-member Board of Directors which will include representatives from non-public education service providers, parents' associations, teachers' unions, the Ministry of Finance and the Ministry of Education.
} 
intend to continue the ongoing efforts to improve care for those already infected and to raise awareness and prevention.

37. To improve access and the quality of water as well as the provision of sanitation, the Government plans to implement the following actions and reforms: (i) reorganize the public institutions of the water sector; (ii) improve and protect water sources; and (iii) ensure the regular collection of solid residues. The Government plans to define its agenda for other sectors, notably environment, infrastructure, manufacturing and tourism. The I-PRSP introduces the broad lines for the development of these sectoral strategies. Given the nature and depth of the challenges facing Haiti and the existing weak institutional capacity, the impact of the reforms is expected to be incremental and have a medium to long term horizon.

\section{Debt Sustainability Analysis (DSA) And Enhanced HIPC Assistance}

\section{A. Debt Reconciliation Status}

38. The DSA presented below was prepared jointly by the authorities and the staffs of IDA and the IMF, based on loan-by-loan data for public and publicly-guaranteed debt outstanding and disbursed as of end-September 2005 provided by the authorities and creditors. The reconciliation process was completed in September 2006, with 100 percent of multilateral and bilateral debt reconciled. ${ }^{30}$

\section{B. Structure of External Debt}

\section{Haiti's public and publicly guaranteed external debt was estimated at}

US\$1.3 billion in nominal terms as of end-September 2005, equivalent to US\$932.9 million in NPV terms (Table 3 and A1). ${ }^{31}$ Multilateral creditors accounted for 82.2 percent of the total, with IDA and the IDB representing 37.9 percent and 40.0 percent of total claims,

\footnotetext{
${ }^{30}$ Compared to the preliminary document, the decision point document includes bilateral loans administered by IDA. This translates into an increase in the stock of outstanding debt at end-September 2005 of approximately US\$4 million (US\$1.5 million in NPV terms). Furthermore, a loan administered by the IDB for the Venezuelan Trust Fund has been reclassified from multilateral to bilateral. The decision point document also incorporates a small revision to the NPV of multilateral debt at end-September 2005, compared to the estimate in the preliminary HIPC document. In the preliminary document, the concessionality included in the arrears clearance operation of IDA was estimated at US\$32.8 million in NPV terms, which has been revised to US\$33.1 million. The estimate for the IDB Group remains unchanged.

31 These estimates are based on scheduled debt service of current maturities and, therefore, do not reflect the simulation of full delivery of traditional debt relief.
} 
respectively. ${ }^{32}$ Bilateral creditors accounted for 17.8 percent of Haiti's external debt, with Paris Club creditors accounting for 14.4 percent. $^{33}$

40. Bilateral creditors have indicated their willingness to reschedule arrears and debt service payments in the context of the PRGF arrangement and the HIPC decision point. Italy, France, and Spain are the largest bilateral creditors, with 5.2 percent, 4.8 percent and 2.9 percent of total claims, respectively. Claims by these creditors include approximately US\$35.4 million in arrears. Haiti has obtained an informal deferral on debt service payments from Italy, France, and Spain during the program supported by the EPCA.

Table 3: Haiti: External Debt, end-September 2005

\begin{tabular}{|c|c|c|}
\hline & $\begin{array}{c}\text { US\$ } \\
\text { million }\end{array}$ & $\begin{array}{l}\text { Percentage } \\
\text { of total }\end{array}$ \\
\hline Total & $1,336.3$ & 100.0 \\
\hline Multilateral & $1,097.8$ & 82.2 \\
\hline IDA & 507.1 & 37.9 \\
\hline IDB Group & 533.9 & 40.0 \\
\hline Other & 56.8 & 4.2 \\
\hline Bilateral & 238.5 & 17.8 \\
\hline \multicolumn{3}{|l|}{ Memorandum Items: } \\
\hline $\begin{array}{l}\text { NPV of debt after } \\
\text { traditional debt relief }\end{array}$ & 928.3 & $\cdots$ \\
\hline $\begin{array}{l}\text { percentage of } \\
\text { exports }\end{array}$ & 176.7 & $\cdots$ \\
\hline
\end{tabular}

41. Arrears to all multilateral creditors have been cleared. In 2004, Haiti cleared about US\$1 million in arrears to the International Fund for Agricultural Development (IFAD) and the OPEC Fund for Development. Concessional arrears clearance operations were also approved by the IDB and IDA. In particular, Haiti cleared US\$30.9 million in arrears to the IDB in July 2003, and US\$52.3 million to IDA in January 2005. The NPV reduction contained in these operations is estimated at US\$33.1 million for IDA and US\$9.7 million for the IDB Group. In accordance with the methodology agreed with multilateral development

\footnotetext{
32 The IDB is one of Haiti's main donors, supporting actions and policies in many areas, including public expenditure management, infrastructure and the provision of basic social services.

${ }^{33}$ Haiti has no external commercial creditors.
} 
banks, the NPV of Haiti's external debt (as of end-September 2005) includes the NPV reduction contained in the arrears clearance operations of the IDB and IDA. ${ }^{34}$

\section{Possible HIPC Initiative Assistance}

\section{Haiti's debt in NPV terms, after full application of traditional debt relief} mechanisms, is estimated at US\$928.3 million (as of end-September 2005). This is equivalent to 176.7 percent of exports of goods and services (Table A2). ${ }^{35}$ Haiti qualifies for debt relief under the HIPC Initiative's export window, having an NPV of debt-to-exports ratio above the 150 percent threshold.

\section{The reduction of Haiti's NPV of debt-to-exports ratio from 176.7 percent to} 150 percent would require HIPC debt relief of US\$140.3 million in NPV terms. This implies a common reduction factor of 15.1 percent. Based on proportional burden sharing, multilateral assistance would amount to US\$120.0 million (in NPV terms) and bilateral assistance to US\$20.4 million (in NPV terms).

44. The modalities and timing of the delivery of the HIPC Initiative assistance will be decided by each creditor following the approval of the decision point. Nevertheless, in order to assess the impact of the HIPC Initiative assistance the following assumptions have been made $^{36}$ :

- IDA will provide assistance amounting to US\$52.8 million in NPV terms, including US\$33.1 million already provided through the concessional rescheduling of arrears. Immediately following the approval of the decision point by the Boards of IDA and the IMF, IDA will begin to provide the remaining assistance (US\$19.7 million) in the form of debt-service reduction on debt outstanding and disbursed as of end-September 2005.

- IMF assistance is estimated at US\$3.1 million in NPV terms. Immediately following the approval of the decision point by the Boards of IDA and the IMF, the IMF will extend interim assistance-provided that the necessary financing assurances are in place - in the form of debt-service reduction. Following the approval of the prospective PRGF arrangement, Haiti is expected to repurchase the amounts outstanding under the EPCA with more concessional PRGF resources. This would result in relatively low levels of debt service falling due

\footnotetext{
${ }^{34}$ See the attachment to "HIPC Debt Initiative: the Chairman's Summary of the Multilateral Development Banks’ Meeting,” March 6, 1998, IDA/Sec M98-90.

35 The NPV of debt-to-export ratio is calculated using a backward-looking three-year average of exports of goods and services.

${ }^{36}$ In line with the government's objectives, Haiti is assumed to reach completion point in September 2008.
} 
during the interim period. As a consequence, most of the IMF's HIPC Initiative assistance is expected to be disbursed after the completion point. ${ }^{37}$

- The IDB assistance will amount to US\$60.4 million in NPV terms, including US\$9.7 million already provided through the concessional rescheduling of arrears. ${ }^{38}$ The remaining US\$50.7 million (in NPV terms) in assistance is expected to be delivered through a reduction in debt service.

- All other multilateral creditors are assumed to provide debt-service reduction starting at the decision point or the completion point, until their contributions meet the requirement under the HIPC Initiative.

- Paris Club bilateral creditors are assumed to provide a flow rescheduling on Cologne terms - i.e., a 90 percent NPV reduction - after Haiti reaches the decision point, with delivery of the remaining required assistance at the completion point through a stock-of-debt operation. The rescheduling on Cologne terms is expected to translate into US\$14.9 million in NPV terms.

- Comparable treatment would be provided by non-Paris Club official bilateral creditors.

45. Based on these assumptions, the HIPC Initiative would provide debt relief totaling US\$ 212.9 million (in nominal terms) over time. This represents a contribution of US\$ 110.9 million from multilateral creditors and US\$ 102.0 million from bilateral creditors. Interim debt relief is estimated to amount to US\$19.8 million, US\$13.3 million in FY2007 and US\$6.5 million in FY2008 (Table A4). ${ }^{39}$

46. Status of creditor participation. IDA and IMF staffs have initiated consultations with multilateral creditors and the Paris Club. So far, IDA, IMF, IDB, IFAD, and Paris Club creditors have indicated their willingness to provide HIPC Initiative debt relief to Haiti. ${ }^{40}$ These creditors account for 95.7 percent of total HIPC Initiative relief.

\footnotetext{
${ }^{37}$ The preliminary HIPC document did not take into account the repurchase of the amounts outstanding under the EPCA with PRGF resources because it had not yet been approved by the IMF Board. The decision point document is presented together with the request for a PRGF arrangement, and hence incorporates the repurchase. This implies revisions, relative to the preliminary document, of the NPV of debt to the IMF and debt service to the IMF from 2007 onwards.

${ }^{38}$ The IMF and IDA have requested the IDB, as well as other multilateral creditors, to confirm their intention to provide assistance to Haiti under the HIPC Initiative. The IMF and IDA have also requested the views of the IDB on the estimate of the concessionality provided through its rescheduling of arrears.

${ }^{39}$ Interim assistance is estimated to fall in FY2008, reflecting a decline in interim assistance from IDA due to the limitation of the one third limit on NPV of assistance during the interim period (Table A10).

${ }^{40}$ The IDB and IFAD have agreed, in principle, to provide HIPC debt relief to Haiti.
} 


\section{Debt Sustainability Analysis}

\section{The debt sustainability analysis presented in this section is based on an updated macroeconomic framework compared to the preliminary document (see Box 1).}

However, the main assumptions underpinning the macroeconomic framework remain broadly unchanged. The framework assumes sustained economic growth, underpinned by improved security and political stability, the decisive implementation of structural reforms, particularly in the areas of economic governance, and infrastructure improvement to promote private investment. The framework also assumes the continuation of sound macroeconomic policies, including maintaining fiscal prudence while increasing revenues and seeking concessional external financing.

48. Under the updated macroeconomic framework and assuming the unconditional delivery of HIPC Initiative assistance, Haiti's NPV of debt-to-exports ratio is expected to fall gradually from 150 percent as of end-September 2005, to approximately 99 percent by 2025 (Table A5). ${ }^{41}$ The NPV of debt-to-exports ratio is expected to remain consistently below the HIPC threshold of 150 percent throughout the projection period. External debt service as a ratio of exports is also expected to decline gradually.

\section{E. MDRI and Possible Bilateral Assistance Beyond HIPC}

49. Haiti would qualify for MDRI debt relief from IDA upon reaching the completion point. However, at completion point Haiti is not expected to have eligible debt for MDRI relief from the IMF. ${ }^{42}$ The MDRI debt relief provided by IDA would cover all outstanding debt disbursed prior to end-December 2003 (that is not already subject to HIPC debt relief), and MDRI debt relief would start at the beginning of the quarter following the completion point.

50. MDRI debt relief from IDA could amount to US\$464.4 million in nominal terms (US\$243.3 million in NPV terms), assuming that Haiti reaches the completion point by endSeptember 2008. This compares with possible HIPC Initiative assistance of US\$212.9 million (US\$140.3 million in NPV terms). Haiti would forgo an estimated US\$18.6 million in debt relief in the event of a one year delay in reaching completion point.

\footnotetext{
${ }^{41}$ Calculations based on staff projections for end-September 2006 suggest that Haiti's debt in NPV terms could reach 150 percent of exports of goods and services in 2007 without receiving HIPC Initiative assistance.

${ }^{42}$ Haiti is scheduled to repay all eligible debt - debt that was outstanding to the IMF before December 31, 2004 - by December 2006.
} 


\section{Box 1. Key Macroeconomic Assumptions Underlying the DSA}

Key medium-to-long term macroeconomic assumptions used in the baseline DSA scenario include:

Annual real GDP growth averages 4.2 percent over the projection period (FY2006-25).

CPI inflation is projected to decelerate from 12.4 percent in FY2006 to 5.0 percent in the long term.

Investment ratio is projected to increase by over 4.0 percentage points of GDP in the long term. Public investment is expected to increase from 5.0 percent of GDP in 2006 to about 7.6 percent of GDP in FY2009.

Fiscal policy aims at achieving the Government's spending priorities while maintaining macroeconomic stability. Central Government revenues are expected to increase gradually from 10.2 percent of GDP in 2006 to about 16.0 percent of GDP by FY2025. Expenditures are expected to increase to almost 21 percent of GDP in the long term with an increased share of pro-poor spending in overall outlays. The central Government overall deficit and external financing requirements, before HIPC Initiative assistance, are projected to average 2.0 percent of GDP over the projection period.

Official loan financing (excluding the IMF) is assumed to be on concessional terms over the projection period, in line with historical experience. IMF loans are expected to be on PRGF terms. Other official loan financing is assumed to be mainly on concessional rates on terms comparable to IDA and the IDB ( 95 percent of total). The remaining 5 percent are assumed to be covered by bilateral donors on less concessional terms. The resulting grant element for new disbursements is estimated at about 45 percent.

External grants are expected to increase at a lower rate than GDP, declining from 5.6 percent of GDP in FY2007 to 2.9 percent by FY2025, as the overall political situation and per capita GDP improve.

The external current account deficit (excluding external grants) is projected to decline gradually from an average of 8.2 percent over the FY2006-2015 period, to 5.2 percent by FY2025.

\section{After conditional delivery of HIPC assistance and MDRI, Haiti's NPV of debt-to-} exports ratio is expected to fall significantly to 91.2 percent at completion point, from an estimated 153.5 percent at the end of FY2007 (Table A6 and Figure 2). It is expected to remain within the 91-102 percent range over the projection period. ${ }^{43}$ Compared to the projection including only HIPC assistance, this represents a reduction of almost 40 percentage points at completion point (Table A6 and Figure 2).

\section{The expected delivery of bilateral assistance beyond that required by the HIPC} Initiative would further reduce the NPV of debt-to-exports ratio to about 94.1 percent by FY2025, compared with the 98.6 percent that would be attained under the HIPC Initiative alone. The amount of possible bilateral assistance beyond HIPC is estimated at about US\$118.1 million in nominal terms.

\footnotetext{
${ }^{43}$ This assumes that MDRI has no impact on Haiti's new borrowing or economic growth over the projection period.
} 


\section{F. Sensitivity Analysis}

\section{Three scenarios are suggested to test the sustainability of Haiti's external debt, after assuming full delivery of HIPC Initiative assistance (Table A7 and Figure 2).}

- The first scenario considers the sensitivity of the projections to less favorable concessionality on new borrowing. Interest rates in this scenario are assumed to be 100 basis points higher than in the baseline scenario. Under this scenario, Haiti's NPV of debt-to-exports ratio slowly deteriorates, compared to the baseline scenario. This deterioration would reach 17.2 percentage points in FY2025, leaving the ratio at about 115.7 percent in 2025 .

- The second scenario considers the sensitivity of the projections to lower exports growth. In this scenario, exports are assumed to grow at 5.0 percent, an average reduction of about 2.5 percentage points compared to the baseline scenario. ${ }^{44}$ Lower export growth is assumed to reduce Government revenues, through lower GDP, and to increase the need for new financing. Based on these assumptions, the NPV of debtto-exports would breach the HIPC threshold in FY2011 and reach 171.7 percent in FY2025 (Table A7). Compared to the baseline scenario, this represents a deterioration of approximately 0.4 percentage points in FY2006, steadily increasing to almost 73.2 percentage points by FY2025.

- The third scenario considers the sensitivity of the projections to lower GDP growth. In this scenario, GDP growth is assumed to be 2.0 percentage points lower on average than in the baseline scenario. Inability to significantly enhance security, improve social and economic infrastructure, and implement structural reforms would weaken private sector confidence and investment. The resulting lower GDP growth would translate into lower Government revenues and the need for increased new borrowing. Under this scenario, the NPV of debt-to-exports would slowly decline until FY2012, reaching 131.8 percent. Thereafter, the NPV of debt-to-exports would gradually increase reaching 161.8 percent by FY2025. Compared to the baseline scenario, this represents an increase in Haiti's NPV of debt-to-exports ratio of about 0.4 percentage points in FY2006 increasing to 63.2 percentage points by FY2025.

\section{The sensitivity analysis indicates that Haiti's exports performance is pivotal to} service its external debt after HIPC assistance. ${ }^{45} \mathrm{~A}$ robust external debt position would also be contingent on vigorous real GDP growth and the composition and terms of external assistance. The analysis also underscores the importance of strong and sustained Government's efforts to: (i) re-establish security; (ii) provide a conducive environment for

\footnotetext{
${ }^{44}$ In this scenario, export growth is set at 5.0 percent, equivalent to the average over the last three years (12 percent) minus one standard deviation (7 percent).

${ }^{45}$ However, the sensitivity analysis does not consider the impact of MDRI or additional bilateral assistance.
} 
private investment, notably through infrastructure improvement and strengthening of state institutions, to develop exportable production (traditional and nontraditional); and (iii) implement a prudent debt management strategy. For their part, donors will need to ensure that external assistance is heavily weighted toward grants.

\section{The Floating Completion Point}

\section{A. Triggers for the Floating Completion Point}

\section{IDA and IMF staffs have reached understandings with the authorities on the} completion point triggers, summarized in Box 2. The triggers incorporate the views expressed by Executive Directors during the discussions of the preliminary HIPC document. In addition to the standard triggers on the PRSP, macroeconomic stability, medium-term macroeconomic framework, tracking of poverty related expenditures, and alignment of priority expenditures with those identified in the I-PRSP and PRSP, there are specific and monitorable policy measures on public finance management and governance, tax policy and administration, social sectors, and external debt management. These triggers support the economic and social development of Haiti and are considered essential to the success of the HIPC Initiative in the country. Public finance management and governance triggers reflect the need to (i) strengthen public finance management and transparency, notably in the areas of budget management, public expenditure controls and procurement; (ii) enhance accountability of high public sector officials for their sources of income and assets; and (iii) promote governance and transparency in key public enterprises. Triggers on tax policy and administration are intended to increase the revenue-to-GDP ratio, which is considerably lower in Haiti than in other PRGF-eligible countries. The Government plans to meet the triggers within two years of the HIPC Decision Point. ${ }^{46}$

\section{B. Monitoring the Floating Completion Point Triggers}

\section{IDA and IMF staffs will work together to monitor the completion point triggers,} with each institution leading on issues where its staff has primary competence, while also incorporating contributions of the staff from the other institution. IMF staff will take the lead in monitoring macroeconomic stability and budget control and management. IDA staff will take the lead in monitoring progress in the preparation of the PRSP, as well progress on sector-related triggers, including those pertaining to governance, service delivery, and tracking poverty-related expenditures (including those financed by HIPC Initiative assistance). IDA and IMF staffs will jointly monitor structural reform and progress in improving external debt management.

\footnotetext{
${ }^{46}$ The triggers were formulated in consultation with the authorities. The actions and policies included are part of the Government's agenda, as specified in the I-PRSP and the extended ICF, and have ongoing or planned financial support from many donors and are expected to benefit also from HIPC resources.
} 


\section{Box. 2 Triggers for the Floating Completion Point}

1. PRSP: Preparation of a full PRSP through a participatory process and satisfactory implementation of its recommended actions for at least one year, as evidenced by an Annual Progress Report submitted by the Government to satisfaction of IDA and the IMF.

2. Macroeconomic Stability: Maintenance of macroeconomic stability as evidenced by satisfactory performance under the PRGF-supported program.

3. Public Finance Management and Governance: (a) Adoption of an automated mechanism to track public expenditures for poverty reduction on the basis of existing expenditure classification, publication of quarterly reports on these expenditures executed over a period of at least six months preceding completion point; (b) Alignment of public spending priorities with the I-PRSP, and, when completed, the PRSP, reflecting emphasis on pro-poor growth; (c) Up-todate preparation of Government accounts by the MEF and their annual audit by the CSCCA, submission to Parliament and publication of audited Government accounts following generally accepted audit standards and legally mandated timetable; (d) Adoption and satisfactory implementation of a new public procurement law, in line with international best practice. Compliance by all Government purchasing agencies evidenced by independent audit of contracts above US\$1m equivalent and also of a representative random sample of all other Government contracts, awarded during the 6 months preceding the audit; (e) Adoption of a law on asset declaration and submission to the CSCCA and to the Parliamentary ethics and anticorruption commissions of at least one annual compliance report on the monitoring of the asset declarations covering the preceding year. $^{47}$

4. Structural Reforms: Strengthen tax administration and policy by: (a) reinforcing and establishing customs control in Cap Haïtien, Gonaives, Saint Marc, Miragoane, Malpasse, Ouanaminthe and Belladere, including by installing ASYCUDA; (b) extending use of the central taxpayer file to all taxpayers in the Port-au-Prince metropolitan zone and registering in it all the taxpayers identified in the tax centers of Cayes, Miragoane, Saint Marc, Port de Paix, Cap Haitien and Fort Liberté.

5. Social sectors: Education (a) Adoption and satisfactory implementation of a public financing mechanism to help poor families pay for costs of school fees in non-public schools to allow enrollment of an additional 50,000 out-of-school children in primary school as evidenced by the results of an independent audit of schools receiving public transfers; (b) Actual recurrent expenditures for education reach at least 21 percent of actual total recurrent Government spending, of which at least 50 percent is spent on primary education, over the 12 months preceding completion point, enabling inter alia the training of 2,500 new primary teachers (at least 1 year) and on average two visits per year of all primary schools by MENJS inspectors. Health and HIV/AIDS: Increase by at least 10 percentage points immunization rates for DPT3, BCG and measles; approval by the Government of National Policy, Strategic Plan and Scale up Operational Plan for HIV/AIDS prevention and treatment.

6. Debt management: (a) Centralization of all information on public external and domestic foreign currency debt in a single database; (b) publication of two consecutive up-to-date quarterly reports on external debt data with a maximum 3 month lag in the period immediately before the completion point.

\footnotetext{
${ }^{47}$ The law would 1) require, at a minimum, that the individuals formally identified by the Constitution and public officials designated as comptables des deniers publics declare annually i) all assets they, their spouses, and dependent children own or have the beneficial use of, (ii) all income received from whatever source; 2) sanction all individuals who either do not submit a declaration or submit a false one; and 3) assign to the ULCC the responsibility to ensure the monitoring of the evolution of the assets of the aforementioned individuals and to present to the CSCCA and the Parliamentary ethics and anti-corruption commissions the results of its monitoring through annual compliance reports.
} 


\section{The Use and Monitoring of Enhanced HIPC Initiative Assistance}

57. The Government is committed to ensuring that assistance under the HIPC Initiative is used to enhance poverty related spending. Securing the effective use of debt relief assistance for poverty reduction and, more generally, the capacity to implement and monitor a shift in the composition of expenditure toward poverty-related objectives is a key element of the HIPC Initiative. The authorities will continue their ongoing efforts to strengthen the programming, management and control of public expenditures, and to improve service delivery in key sectors. Within this framework, the technical assistance that is already being provided by IDA, IMF, IDB and other donors will be important to establish adequate budget management capacity.

58. While Haiti does not have a budget classification by program or a fully functional budget classification, there are mechanisms in place that can be used to adequately monitor the use of resources made available by the HIPC Initiative. The June 2006 joint IMF and IDA Assessment and Action Plan (AAP) for tracking poverty-related expenditure concluded that the recently introduced budget and accounting classifications allow monitoring of budget allocations and expenditures following two dimensions:

(i) administrative (ministries, central and regional departments) including development projects; and (ii) economic (expenditure types). The budget is also presented in the annexes of the budget law following a functional classification with 10 broad categories (such as education and health). The functional classification is prepared from broad estimates from the administrative classification. Also, in the absence of a program budget, projects are individually coded within the administrative classification allowing recording and reporting on projects' expenditures.

59. On the basis of the AAP recommendations, the use of resources made available by the HIPC Initiative prior to completion point will be monitored at the entity (e.g., ministries, public institutions, and executing agencies) and the project levels. Entities, which are already coded in the budget classification, will be identified according to their core mandate in relation with poverty reduction. The same process will be followed to identify individual projects in areas which contribute to poverty reduction as defined in the I-PRSP. There are already mechanisms in place to record expenditures according to their destinations. This will allow monitoring both budget allocations and expenditures for both the entities and projects identified as contributing to poverty reduction. ${ }^{48}$

\section{The Government intends to use HIPC related savings to fund activities identified}

in the I-PRSP and which will be included in the PRSP. The relatively limited resources from HIPC initiative assistance would focus largely on health, education, water and environment while other areas, such as major infrastructure programs, would be financed by other external resources (Box 3). The poverty-related programs and projects to be financed

\footnotetext{
${ }^{48}$ The process of identification of entities and projects is ongoing. IDA staff will be assessing progress in early November 2006.
} 
within the interim assistance have been included in the FY2007 budget and would need to be included in subsequent budgets. In addition, IDA's ongoing Economic Governance Technical Assistance Grant II (EGTAG II) and a follow-on Economic Governance Reform Operation II (EGRO II) currently under preparation will provide resources to strengthen and modernize the public procurement system with the above mentioned adoption and implementation of a new procurement law promoting transparency and competition in line with international best practices.

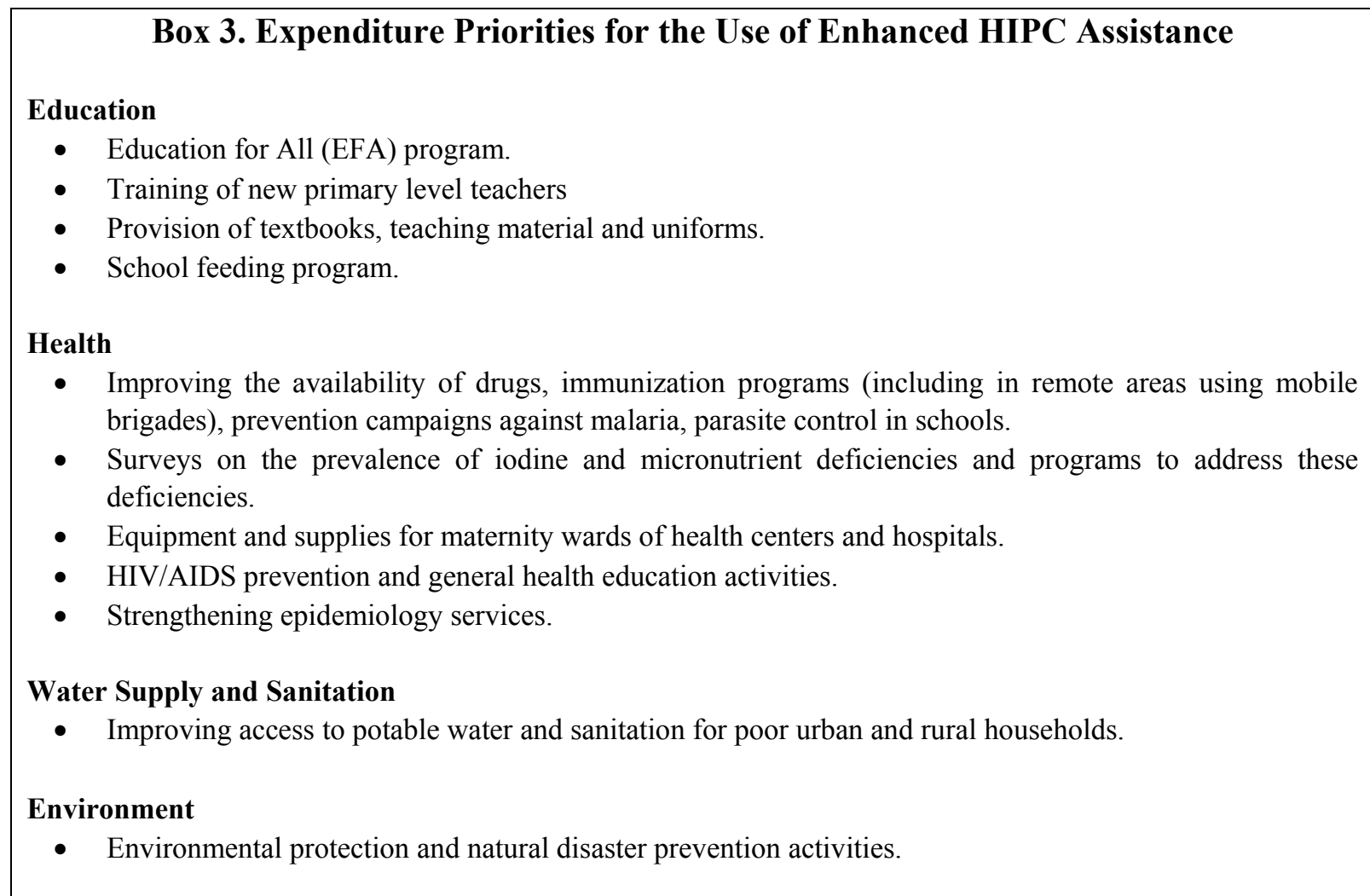

61. The periodic budget execution reports published by the MEF on its web page provide a tool to monitor and publicly disseminate the use of resources made available by the HIPC Initiative in-year. Measures are also being taken to become current with the audit of the annual Government accounts by the CSCCA. This will provide external and independent validation of the budget execution reports. The Government intends to institutionalize monitoring and evaluation mechanisms in the context of the PRSP, which will have an important role in providing oversight on the allocation of resources for poverty reduction, notably savings from debt relief.

\section{The Views of the Authorities}

62. The authorities have emphasized that Haiti's external debt burden and debt service are unsustainably high and could delay the economic and social reform programs. They have also noted that Haiti is the poorest country in the Western Hemisphere 
and one of the poorest in the world, with a significant share of the population lacking access to basic services such as education, health and safe water. The authorities have indicated that the violence and political instability that marred the country aggravated the level of poverty, especially in urban slums. Debt relief that could be available under the HIPC Initiative would help free resources to finance critical social and infrastructure programs as well as improve access to primary education, preventive health care and the fight against HIV/AIDS. For the authorities, the resulting improvements in social conditions will help in the efforts to reverse violence and political instability.

\section{ISSUES FOR DISCUSSION}

63. This paper presents a decision point assessment of Haiti's qualification for assistance under the HIPC Initiative. Executive Directors' views and guidance are sought in particular on the following issues:

- Qualification and decision point: Do Directors agree that Haiti qualifies for assistance under the HIPC Initiative, and do they recommend approval of a decision point?

- Amount and delivery of assistance: In order to reduce the NPV of debt to exports ratio to 150 percent, the total amount of assistance under the HIPC Initiative is estimated at US\$140.3 million in NPV terms (Table A2). Of this amount, IDA would provide total assistance amounting to US\$52.8 million in NPV terms, including an estimated US\$33.1 million related to the concessional rescheduling of arrears in early 2005. IMF assistance would total US\$3.1 million in NPV terms. The staff and management recommend that IDA and the IMF provide interim assistance in line with existing guidelines. Do Directors agree that the IMF and IDA should provide interim assistance between the decision and completion points, in line with existing guidelines?

- Completion Point: Do Executive Directors agree that the floating completion point will be reached when the triggers in Box 2 have been met? Debt relief will be provided unconditionally only when the completion point triggers have been met and satisfactory assurances have been received of other creditors' participation under the enhanced HIPC Initiative for Haiti. 
Figure 1A. Haiti: Composition of Stock of External Debt at End-September 2005 by creditor group

(Nominal stock: \$1.336 million)

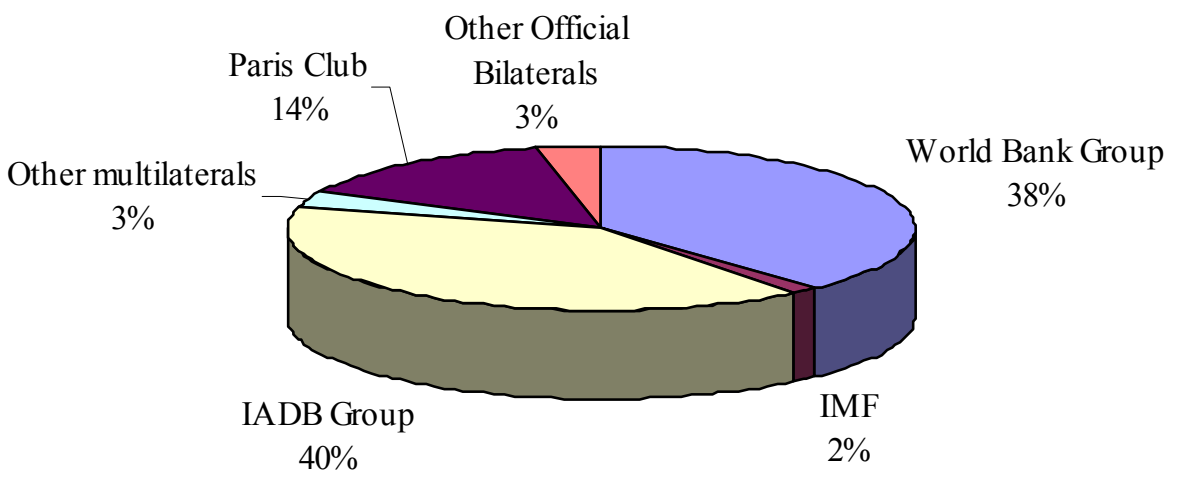

Figue 1B. Haiti: Potential costs of the HIPC Initiative

by creditor group

(Total Estimated HIPC Enhanced Assistance: \$140 million, end-September 2005 NPV terms)

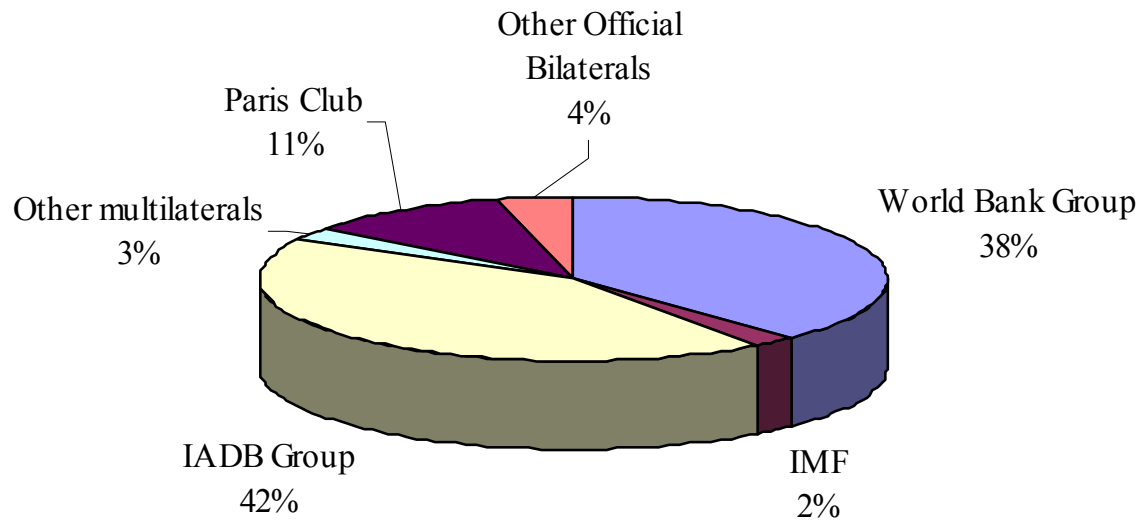


Figure 2. Haiti: External Debt

Sustainability Indicators, 2005-25

NPV ofDebt to Exports

(In percent of Exports)

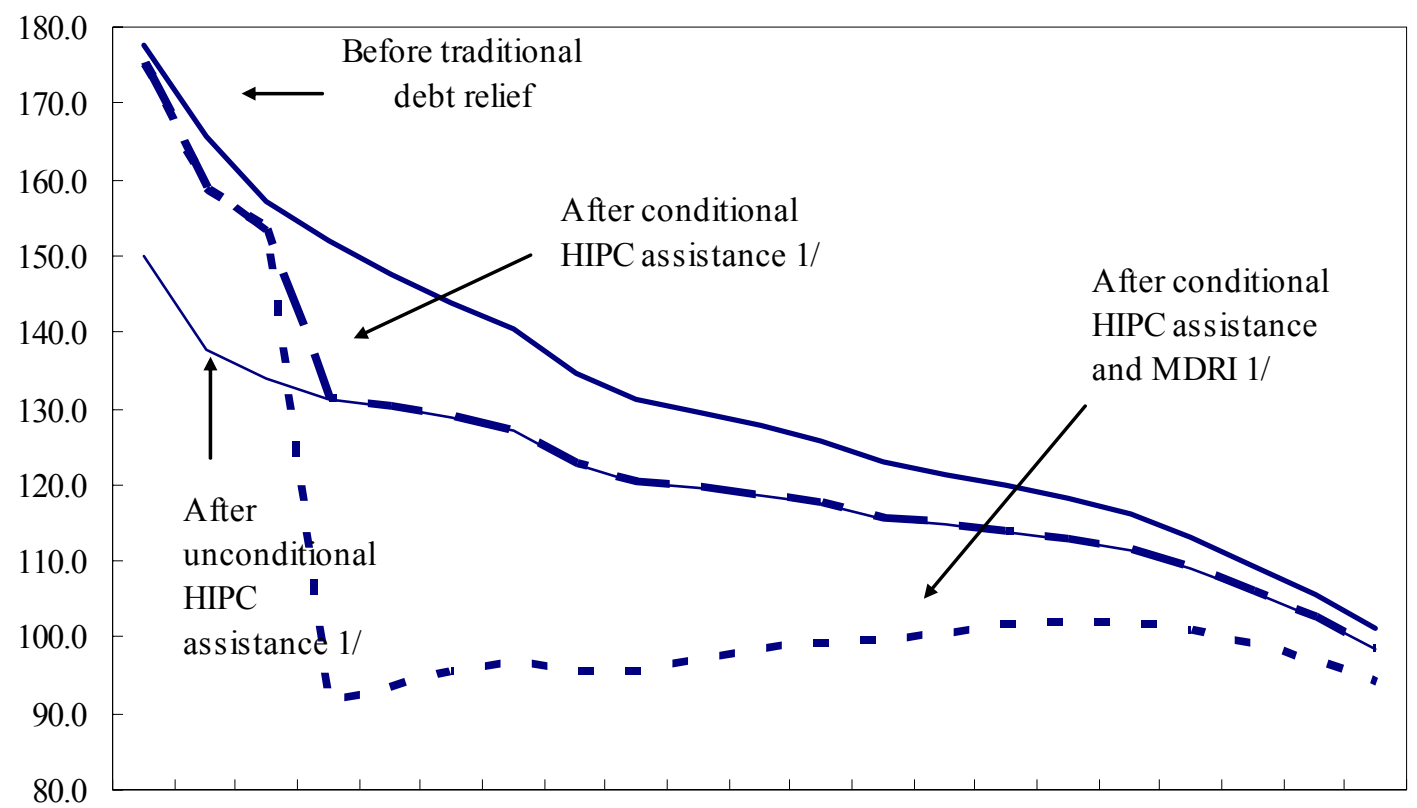

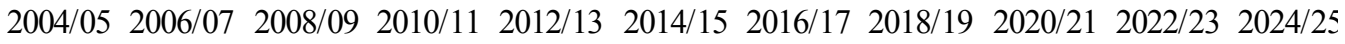

Debt Service to Exports

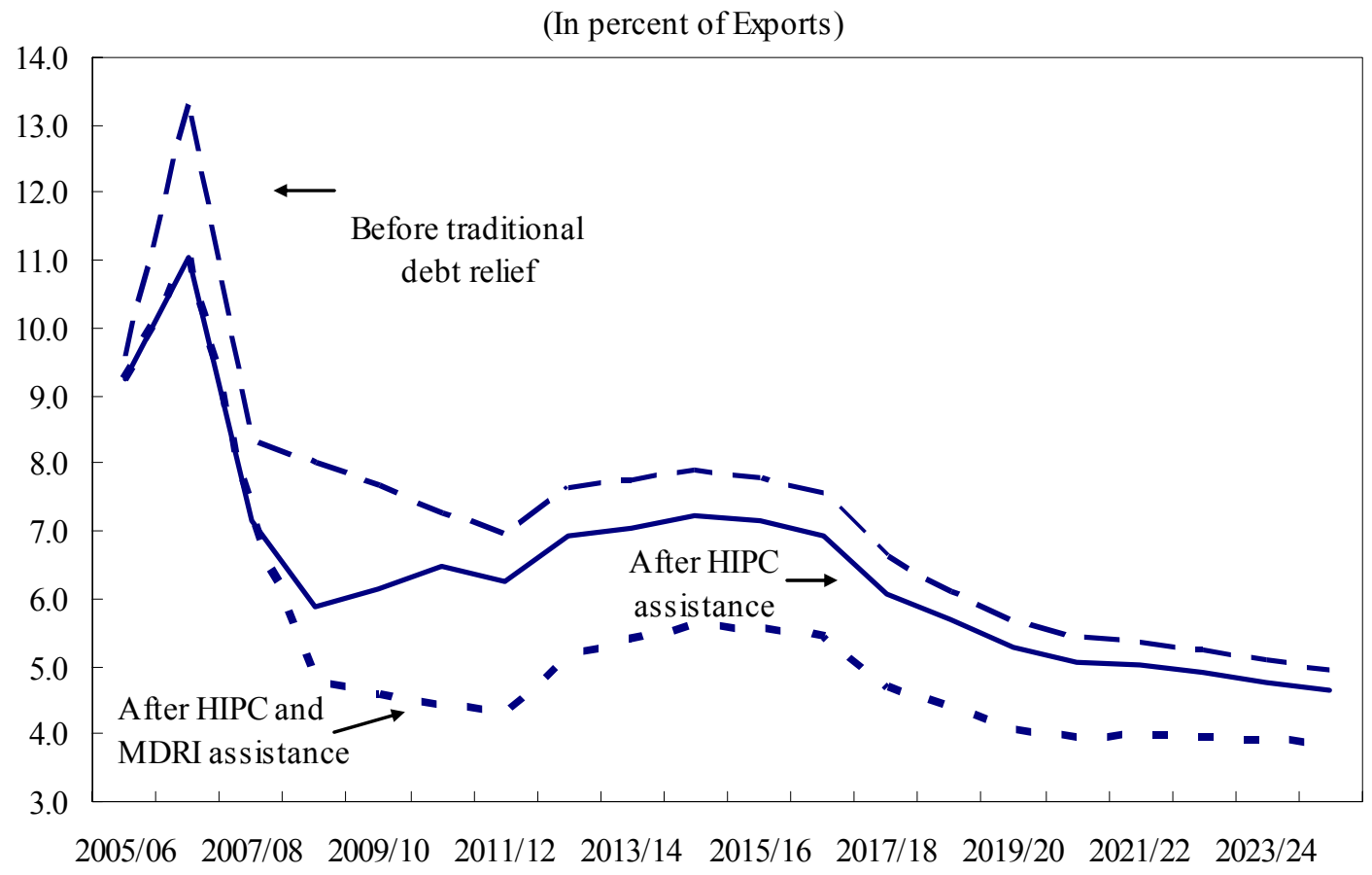

(C)International Monetary Fund. Not for Redistribution 
Figure 3. Haiti: Sensitivity Analysis, 2005-25

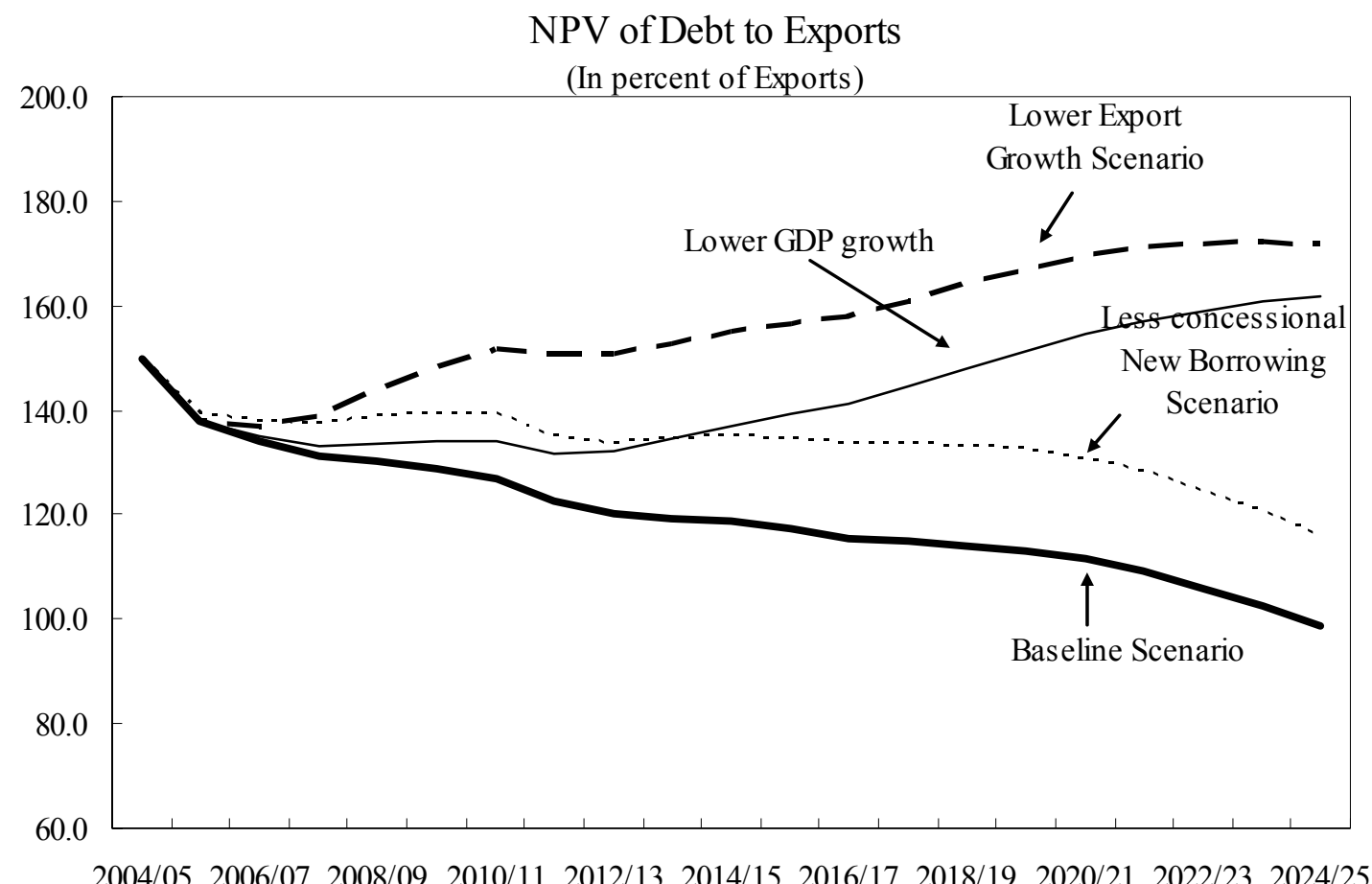

Debt Service to Exports

(In percent of Exports)

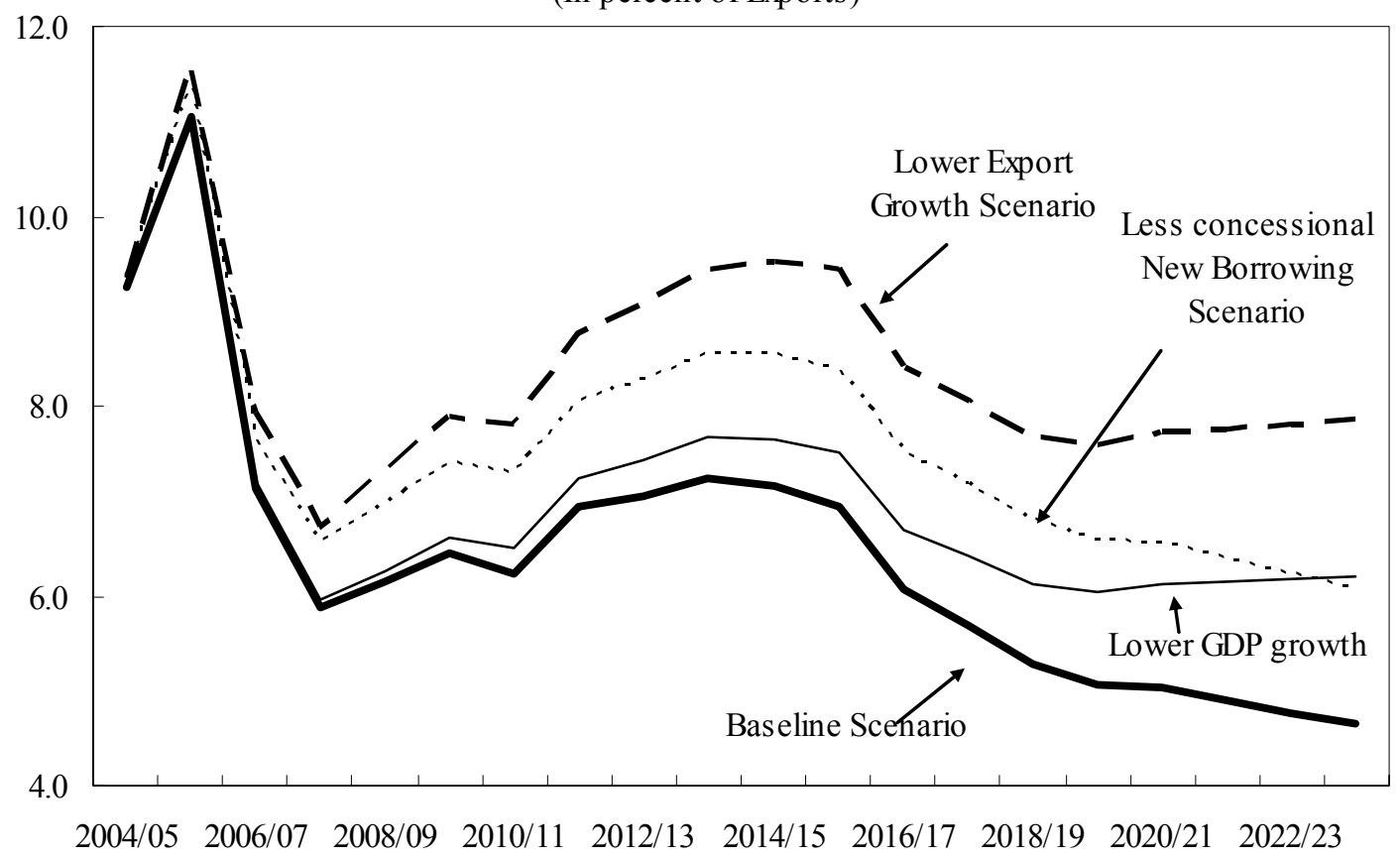


Table A1. Haiti: Nominal Stock and Net Present Value of Debt at end-September 2005 by Creditor Groups (In million of US\$ unless otherwise specified)

\begin{tabular}{|c|c|c|c|c|c|c|c|c|}
\hline & \multicolumn{2}{|c|}{ Nominal Debt Stock } & \multicolumn{2}{|c|}{ Arrears } & \multicolumn{2}{|c|}{ NPV of Debt } & \multicolumn{2}{|c|}{$\begin{array}{c}\text { NPV of Debt After Traditional } \\
\text { Debt Relief } 1 / 2 / \\
\end{array}$} \\
\hline & & $\begin{array}{l}\text { Percent } \\
\text { of total }\end{array}$ & & $\begin{array}{l}\text { Percent } \\
\text { of total }\end{array}$ & & $\begin{array}{l}\text { Percent } \\
\text { of total }\end{array}$ & & $\begin{array}{l}\text { Percent } \\
\text { of total }\end{array}$ \\
\hline Total & $1,336.3$ & 100.0 & 35.4 & 100.0 & 932.9 & 100.0 & 928.3 & 100.0 \\
\hline Multilateral & $1,097.8$ & 82.2 & 0.0 & 0.0 & 750.6 & 80.5 & 793.5 & 85.5 \\
\hline World Bank & 507.1 & 37.9 & 0.0 & 0.0 & 316.3 & 33.9 & 349.4 & 37.6 \\
\hline IMF & 21.4 & 1.6 & 0.0 & 0.0 & 20.6 & 2.2 & 20.6 & 2.2 \\
\hline IADB Group & 533.9 & 40.0 & 0.0 & 0.0 & 389.9 & 41.8 & 399.6 & 43.1 \\
\hline IFAD & 31.7 & 2.4 & 0.0 & 0.0 & 20.3 & 2.2 & 20.3 & 2.2 \\
\hline OPEC & 3.7 & 0.3 & 0.0 & 0.0 & 3.4 & 0.4 & 3.4 & 0.4 \\
\hline Bilateral and commercial & 238.5 & 17.8 & 35.4 & 100.0 & 182.2 & 19.5 & 134.8 & 14.5 \\
\hline Paris Club & 192.7 & 14.4 & 35.4 & 100.0 & 145.7 & 15.6 & 98.4 & 10.6 \\
\hline Canada & 2.0 & 0.2 & 0.0 & 0.0 & 2.1 & 0.2 & 2.1 & 0.2 \\
\hline EEC IDA administered & 4.0 & 0.3 & 0.0 & 0.0 & 2.7 & 0.3 & 1.5 & 0.2 \\
\hline France & 64.1 & 4.8 & 23.3 & 65.9 & 59.7 & 6.4 & 45.7 & 4.9 \\
\hline Italy & 68.9 & 5.2 & 7.8 & 22.0 & 44.2 & 4.7 & 24.2 & 2.6 \\
\hline Spain & 38.6 & 2.9 & 4.3 & 12.0 & 24.1 & 2.6 & 13.6 & 1.5 \\
\hline United States & 15.1 & 1.1 & 0.0 & 0.0 & 13.0 & 1.4 & 11.4 & 1.2 \\
\hline Other Official Bilateral & 45.8 & 3.4 & 0.0 & 0.0 & 36.5 & 3.9 & 36.4 & 3.9 \\
\hline Taiwan, People's Republic of China & 45.7 & 3.4 & 0.0 & 0.0 & 36.3 & 3.9 & 36.3 & 3.9 \\
\hline Venezuela & 0.1 & 0.0 & 0.0 & 0.0 & 0.1 & 0.0 & 0.0 & 0.0 \\
\hline
\end{tabular}

Sources: Haitian authorities and staff estimates.

1/ Includes a stock-of-debt operation on Naples terms at end-September 2005; and comparable action by other official bilateral creditors on eligible debt (precutoff and non-ODA).

2/ The increase in the NPV of debt for the IADB Group and the World Bank reflects the impact of the arrears clearance operations undertaken in 2003 and 2005, respectively. The NPV reduction contained in these operations is estimated at US\$9.7 million for the IADB Group and US\$33.1 million for the World Bank. They are considered as part of HIPC relief effort. The IADB Group used concessional resources from its Fund for Special Operations (FSO). 
Table A2. Haiti: HIPC Initiative -- Assistance Under a Proportional Burden-Sharing Approach 1/ 2/

(In millions of U.S. dollars, unless otherwise indicated)

\begin{tabular}{|c|c|c|c|c|}
\hline $\begin{array}{l}\text { NPV of debt- } \\
\text { to-exports-target } \\
\text { (in percent) }\end{array}$ & $\begin{array}{l}\text { Total } \\
\qquad \text { (In }\end{array}$ & Bilateral 3/ & Multilateral & $\begin{array}{c}\text { Common Reduction } \\
\text { Factor 4/ } \\
\text { (Percent) }\end{array}$ \\
\hline 150 & 140.3 & 20.4 & 120.0 & 15.1 \\
\hline \multicolumn{5}{|l|}{ Memorandum items: } \\
\hline NPV of debt $5 /$ & 928.3 & 134.8 & 793.5 & \\
\hline Paris Club creditors & 98.4 & & & \\
\hline Of which: pre-cutoff date non-ODA debt & 50.4 & & & \\
\hline Non-Paris Club creditors & 36.4 & & & \\
\hline Of which: pre-cutoff date non-ODA debt & 0.0 & & & \\
\hline Three-year average of exports & 525.3 & & & \\
\hline Current-year exports & 597.3 & & & \\
\hline NPV of debt-to-exports ratio $6 /$ & 176.7 & & & \\
\hline
\end{tabular}

Sources: Haitian authorities and staff estimates and projections.

1/ The proportional burden sharing approach is described in "HIPC Initiative--Estimated Costs and Burden Sharing Approaches", 7/7/97 and IDA/SEC M 97-306, 7/7/97).

2/ Includes a hypothetical stock-of-debt operation on Naples terms (end-September 2005) and comparable treatment by other official bilateral creditors.

3 / Includes all official bilateral creditors.

4/ Each creditor's NPV reduction in percent of its exposure at the decision point.

5/ Based on end-September 2005 data after full application of traditional debt relief mechanisms. The NPV reduction contained in the ateas operations undertaken by IDA and the IADB Group is included in the NPV of debt.

6/ Based on the three-year export average (backward-looking average, i.e., 2005-03). Note that this includes the impact of the concessional rescheduling of arrears by the World Bank and the IADB Group. 
Table A3. Haiti: Discount and Exchange Rate Assumptions at End-September 2005

\begin{tabular}{lcc}
\hline & Discount Rate 1/ \\
Currency Name & $\begin{array}{c}\text { Exchange Rate 2/ } \\
\text { (In percent per annum) }\end{array}$ & 1.16 \\
\hline Canadian Dollar & 4.80 & 6.20 \\
Danish Kroner & 4.06 & 0.83 \\
Euro & 4.11 & 0.57 \\
Great Britain Sterling & 5.51 & 113.15 \\
Japanese Yen & 1.85 & 6.54 \\
Norwegian Kroner & 4.21 & 0.69 \\
Special Drawing Rights & 4.35 & 7.75 \\
Swedish Kroner & 4.21 & 1.29 \\
Swiss Franc & 2.82 & 1.00 \\
United States Dollar & 5.05 & 2147 \\
Venezuelan Bolivar & 4.35 & \\
Memorandum item: & & \\
Paris Club cutoff date & & \\
& & \\
Sources: OECD; and IMF, International Financial Statistics . & \\
1/ The discount rates used are the average commercial interest reference rates over the six-month period prior \\
to end-September 2005, i.e., the end of the period for which actual debt and export data are available. \\
2/ The exchange rates are expressed as national currency per U.S. dollar at end-September 2005.
\end{tabular}


Table A4. Haiti: External Debt Service, 2006-2025
(in millions of U.S. dollars, unless otherwise indicated)

\begin{tabular}{|c|c|c|c|c|c|c|c|c|c|c|c|c|c|c|c|c|c|c|c|c|c|c|c|}
\hline & $2005 / 06$ & $2006 / 17$ & $2007 / 08$ & $2008 ،$ & & & 2011 & & & & 015 & 316 & & & & & 2020 & & & & & $\begin{array}{l}\text { Avera } \\
2050606 \\
201 / 115\end{array}$ & $\begin{array}{l}\frac{\mathrm{gese}}{2015516} \\
2024 / 25\end{array}$ \\
\hline \multirow{2}{*}{\multicolumn{24}{|c|}{$\begin{array}{l}\text { Before traditional debt relief } \\
\text { Total }\end{array}$}} \\
\hline & & & & & & & & & & & & & & & & & & & & & & & \\
\hline $\begin{array}{l}\text { Multilateral } \\
\text { World Bank Group }\end{array}$ & $\begin{array}{l}49.7 \\
17.3\end{array}$ & $\begin{array}{c}6.6 \\
18.3 \\
18.3\end{array}$ & $\begin{array}{l}50.2 \\
18.5 \\
18\end{array}$ & $\begin{array}{l}50 . \\
18 . \\
\text { s. }\end{array}$ & $\begin{array}{l}51 . \\
19 .\end{array}$ & $\begin{array}{l}50 \\
20\end{array}$ & 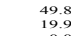 & $\begin{array}{l}49.1 \\
19.8\end{array}$ & $\begin{array}{l}48.9 \\
19.7\end{array}$ & $\begin{array}{l}50.2 \\
20.9\end{array}$ & $\begin{array}{l}50.8 \\
22.2 \\
-\end{array}$ & ${ }_{22.3}^{49.8}$ & $\begin{array}{l}48.8 \\
2.2 \\
-1\end{array}$ & $\begin{array}{l}47 \\
22\end{array}$ & & $\begin{array}{l}46.2 \\
21.9\end{array}$ & $\begin{array}{l}45.5 \\
21.7 \\
-\end{array}$ & $\begin{array}{l}44.7 \\
21.6\end{array}$ & $\begin{array}{l}43.9 \\
21.4\end{array}$ & $\begin{array}{l}42.5 \\
21.3 \\
-10\end{array}$ & $\begin{array}{l}41.3 \\
20.8\end{array}$ & $\begin{array}{l}51.6 \\
19.3\end{array}$ & $\begin{array}{l}46.1 \\
21.7 \\
-1\end{array}$ \\
\hline $\begin{array}{l}\text { IMF 3" } \\
\text { IADB Group }\end{array}$ & $\begin{array}{r}5.0 \\
25.4\end{array}$ & $\begin{array}{l}17.0 \\
28.4\end{array}$ & $\begin{array}{l}0.0 \\
29.8 \\
2\end{array}-8$ & 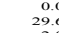 & $\begin{array}{c}\text { o. } \\
29\end{array}$ & $\begin{array}{r}0 . \\
29 \\
\end{array}$ & $\begin{array}{l}0.0 \\
28.6 \\
-10\end{array}$ & $\begin{array}{l}0.0 \\
28.0\end{array}$ & $\begin{array}{r}0.0 \\
27.9\end{array}$ & $\begin{array}{l}0.0 \\
28.0\end{array}$ & $\begin{array}{l}0.0 \\
27.3 \\
27.3\end{array}-100$ & $\begin{array}{l}0.0 \\
26.2 \\
26.2 \\
-1\end{array}$ & $\begin{array}{l}0.0 \\
25.4 \\
25.4\end{array}$ & $\begin{array}{c}0 \\
24 \\
24\end{array}$ & & $\begin{array}{c}0.0 \\
23.1\end{array}$ & $\begin{array}{l}0.0 \\
22.5 \\
22.5\end{array}$ & $\begin{array}{r}0.0 \\
21.9\end{array}$ & $\begin{array}{l}0.0 \\
21.3\end{array}$ & $\begin{array}{l}0.0 \\
20.0\end{array}$ & $\begin{array}{l}0.0 \\
19.3 \\
19.3\end{array}$ & $\begin{array}{l}28.2 \\
28.4\end{array}$ & $\begin{array}{l}0.0 \\
23.1 \\
23.1\end{array}$ \\
\hline $\begin{array}{l}\text { Others } \\
\text { Official bilateral }\end{array}$ & $\begin{array}{c}2.0 \\
10.0 \\
10.2\end{array}$ & $\begin{array}{c}2.0 \\
10.0 \\
10.0\end{array}$ & $\begin{array}{c}1.9 \\
10.0\end{array}$ & $\begin{array}{c}2.4 \\
10 .\end{array}$ & $\begin{array}{c}2 . \\
10 .\end{array}$ & $\begin{array}{c}1 \\
11 \\
\end{array}$ & $\begin{array}{c}1.3 \\
11.7 \\
11.8\end{array}$ & $\begin{array}{c}1.3 \\
11.8 \\
11.8\end{array}$ & $\begin{array}{c}1.3 \\
12.0\end{array}$ & 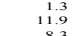 & $\begin{array}{c}1.3 \\
12.0 \\
12.0\end{array}$ & $\begin{array}{c}1.3 \\
12.1\end{array}$ & $\begin{array}{r}1.3 \\
11.9 \\
\mathrm{c}\end{array}$ & $\begin{array}{c}1 \\
10\end{array}$ & $\begin{array}{l}1.3 . \\
0.1 \\
.12\end{array}$ & $\begin{array}{l}1.3 \\
8.4\end{array}$ & $\begin{array}{l}1.3 \\
7.2 \\
-2\end{array}$ & $\begin{array}{l}1.2 \\
7.4\end{array}$ & $\frac{1.2}{7.8}$ & $\begin{array}{l}1.2 \\
8.2\end{array}$ & $\begin{array}{l}1.2 \\
8.0\end{array}$ & $\begin{array}{r}1.7 \\
11.0\end{array}$ & $\begin{array}{l}1.3 \\
9.3 \\
9.3\end{array}-10$ \\
\hline $\begin{array}{l}\text { Non Paris Club } \\
\text { New dobt } 4 \text { irs Clate }\end{array}$ & $\begin{array}{l}2.8 \\
0.8 \\
0.8\end{array}$ & $\begin{aligned} 2.3 \\
2.7 \\
16.8\end{aligned}$ & $\begin{array}{l}2.6 \\
3.6 \\
3.6\end{array}$ & $\begin{array}{l}3.4 \\
5.3\end{array}$ & 3. & 3. & $\begin{array}{r}3.8 \\
1.8 \\
104\end{array}$ & $\begin{array}{l}8.7 \\
22.8 \\
22.8\end{array}$ & $\begin{aligned} 3.3 \\
3.7 \\
29.5\end{aligned}$ & $\begin{aligned} 3.3 \\
36.6 \\
36.4\end{aligned}$ & $\begin{aligned} 8.5 \\
3.5 \\
41.0\end{aligned}$ & $\begin{array}{r}8.5 \\
3.5 \\
4.5\end{array}$ & $\begin{aligned} 8.3 \\
3.4 \\
40.0\end{aligned}$ & $\begin{array}{r}3 \\
42 \\
42\end{array}$ & & $\begin{array}{l}2.4 \\
2.0 \\
44.2\end{array}$ & $\begin{array}{c}5.6 \\
4.6 \\
49.0\end{array}$ & $\begin{aligned} 518 \\
11.6 \\
56.0\end{aligned}$ & $\begin{array}{l}0.2 \\
1.5 \\
61.4\end{array}$ & $\begin{array}{l}1.1 \\
\text { 1.5 } \\
67.6\end{array}$ & $\begin{array}{r}0.8 \\
0.8 \\
74.6\end{array}$ & $\begin{array}{l}3.2 \\
14.2 \\
14.2\end{array}$ & 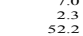 \\
\hline $\begin{array}{l}\text { Debt sevvice to exports ratio } \\
\text { Debt servicect to reverunc ration }\end{array}$ & $\begin{array}{r}9.6 \\
11.8\end{array}$ & $\begin{array}{l}13.4 \\
11.7\end{array}$ & $\begin{array}{c}8.4 \\
11.0\end{array}$ & $\begin{array}{c}8.4 \\
10 .\end{array}$ & 7. & 8. & $\begin{array}{l}7.0 \\
8.4\end{array}$ & $\begin{array}{l}7.6 \\
9.0\end{array}$ & $\begin{array}{l}7.7 \\
9.0\end{array}$ & $\begin{array}{l}7.9 \\
9.0\end{array}$ & $\begin{array}{l}7.8 \\
8.7 \\
\end{array}$ & 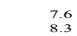 & $\begin{array}{l}6.6 \\
7.1\end{array}$ & 6 & 6.1. & $\begin{array}{l}5.7 \\
5.9\end{array}$ & $\begin{array}{l}5.4 \\
5.6\end{array}$ & $\begin{array}{c}5.4 \\
5.5 \\
.\end{array}$ & $\begin{array}{l}5.2 \\
5.3 \\
-1\end{array}$ & $\begin{array}{c}5.1 \\
5.1\end{array}$ & $\begin{array}{l}4.9 \\
4.9\end{array}$ & $\begin{array}{c}8.5 \\
10.5\end{array}$ & $\begin{array}{l}6.0 \\
6.3 \\
-3\end{array}$ \\
\hline \multirow{2}{*}{\multicolumn{24}{|c|}{$\begin{array}{l}\text { After traditional debt relier } \mathbf{~} \text {, } \\
\text { Total } \\
\text { Existing debt } 2 /\end{array}$}} \\
\hline & $\begin{array}{l}57.6 \\
56.7\end{array}$ & $\begin{array}{l}89.6 \\
72.8\end{array}$ & $\begin{array}{l}61.0 \\
57.4\end{array}-4$ & $\begin{array}{l}63 . \\
58 .\end{array}$ & $\begin{array}{l}6.6 \\
59 .\end{array}$ & $\begin{array}{l}68 . \\
58 .\end{array}$ & $\begin{array}{l}69.4 \\
59.0\end{array}-0$ & $\begin{array}{l}81.2 \\
58.4\end{array}$ & $\begin{array}{l}87.4 \\
57.9\end{array}$ & $\begin{array}{l}95.8 \\
59.4\end{array}$ & $\begin{array}{c}101.2 \\
60.2\end{array}$ & $\begin{array}{c}105.1 \\
59.5\end{array}$ & $\begin{array}{c}98.8 \\
58.8\end{array}$ & $\begin{array}{c}98 \\
55 \\
5\end{array}$ & & $\begin{array}{c}97.6 \\
53.4\end{array}$ & 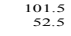 & $\begin{array}{c}108.7 \\
52.7\end{array}$ & $\begin{array}{r}113.6 \\
52.2\end{array}$ & $\begin{array}{r}118.8 \\
51.2\end{array}$ & $\begin{array}{l}124.2 \\
49.6\end{array}$ & $\begin{array}{l}74.0 \\
59.8\end{array}$ & $\begin{array}{c}106.7 \\
54.6\end{array}$ \\
\hline $\begin{array}{l}\text { Multilateral } \\
\text { World Bank Group }\end{array}$ & $\begin{array}{l}49.7 \\
17.3\end{array}$ & $\begin{array}{c}65.6 \\
18.3\end{array}$ & $\begin{array}{c}50.2 \\
18.5\end{array}$ & $\begin{array}{c}50 . \\
18 .\end{array}$ & $\begin{array}{l}51 . \\
19 .\end{array}$ & $\begin{array}{c}50 . \\
20 .\end{array}-20$ & $\begin{array}{l}49.8 \\
19.9\end{array}-9$ & $\begin{array}{l}49.1 \\
19.8\end{array}$ & $\begin{array}{l}48.9 \\
19.7\end{array}$ & $\begin{array}{c}50.2 \\
20.9\end{array}$ & $\begin{array}{l}50.8 \\
22.2\end{array}$ & ${ }_{22.8}^{49.8}$ & ${ }_{22.2}^{48.8}$ & $\begin{array}{l}47 \\
22\end{array}$ & & $\begin{array}{l}46.2 \\
21.9\end{array}$ & $\begin{array}{l}45.5 \\
21.7 \\
2.7\end{array}$ & $\begin{array}{l}44.7 \\
21.6\end{array}$ & $\begin{array}{l}43.9 \\
21.4\end{array}$ & $\begin{array}{l}42.5 \\
21.3\end{array}$ & $\begin{array}{l}41.3 \\
20.8\end{array}$ & $\begin{array}{c}51.6 \\
19.3\end{array}$ & $\begin{array}{l}46.1 \\
21.7\end{array}$ \\
\hline $\begin{array}{l}\text { IMF 3 } \\
\text { IADB Group }\end{array}$ & $\begin{array}{r}5.0 \\
25.4\end{array}$ & $\begin{array}{l}17.0 \\
28.4\end{array}$ & $\begin{array}{c}0.0 .8 \\
29.8\end{array}$ & $\begin{array}{c}0.4 \\
29.4\end{array}$ & $\begin{array}{c}0 . \\
29\end{array}$ & $\begin{array}{c}0 . \\
29\end{array}$ & $\begin{array}{l}0.0 \\
28.6 \\
2\end{array}$ & $\begin{array}{c}0.0 \\
28.0 \\
28.0\end{array}$ & $\begin{array}{r}0.0 \\
27.9\end{array}$ & $\begin{array}{c}0.0 \\
28.0\end{array}$ & 27.3 & $\begin{array}{r}0.0 \\
26.2\end{array}$ & $\begin{array}{l}0.0 \\
25.4\end{array}$ & 24 & & $\begin{array}{c}0.0 \\
23.1\end{array}$ & $\begin{array}{c}0.0 \\
22.5 \\
2.5\end{array}$ & 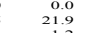 & $\begin{array}{c}0.0 \\
21.3\end{array}$ & $\begin{array}{l}0.0 \\
20.0\end{array}$ & $\begin{array}{c}0.0 \\
19.3 \\
19.3\end{array}$ & 28.2 & $\begin{array}{l}0.0 \\
23.1 \\
23.1\end{array}$ \\
\hline 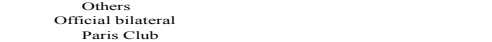 & $\begin{array}{l}2.0 \\
7.0 \\
4.4\end{array}$ & $\begin{array}{l}2.0 \\
7.1 \\
4.4\end{array}$ & $\begin{array}{l}1.9 \\
7.2 \\
4.5\end{array}$ & $\begin{array}{l}2.4 \\
8.4 \\
5.4\end{array}$ & $\begin{array}{l}2 . \\
8 .\end{array}$ & $\begin{array}{l}1 . \\
8 \\
5\end{array}$ & $\begin{array}{l}1.3 \\
9.2 \\
5.4\end{array}$ & $\begin{array}{l}1.3 \\
9.3 \\
5.6\end{array}$ & $\begin{array}{l}1.3 \\
9.0 \\
5.4\end{array}$ & $\begin{array}{l}1.3 \\
9.2 \\
5.6\end{array}$ & $\begin{array}{l}1.3 \\
9.5 \\
5.9\end{array}$ & $\begin{array}{l}1.3 \\
9.7 \\
6.2\end{array}$ & $\begin{aligned} 1.3 \\
10.0 \\
6.6\end{aligned}$ & $\begin{array}{l}1 \\
8 \\
5\end{array}$ & $\begin{array}{l}1.3 \\
8.4 \\
5.1\end{array}$ & $\begin{array}{l}1.3 \\
7.2 \\
5.2\end{array}$ & $\begin{array}{l}1.3 \\
7.0 \\
5.4\end{array}$ & $\begin{array}{l}1.2 \\
8.0 \\
6.4\end{array}$ & $\begin{array}{l}1.2 \\
8.3 \\
6.8\end{array}$ & $\begin{array}{l}1.2 \\
8.6 \\
7.1\end{array}$ & $\begin{array}{l}1.2 \\
8.3 \\
7.6\end{array}$ & $\begin{array}{l}1.7 \\
8.3 \\
5.0\end{array}$ & $\begin{array}{l}1.3 \\
8.5 \\
6.2\end{array}$ \\
\hline $\begin{array}{l}\text { Non Paris Club } \\
\text { New debt } 4 /\end{array}$ & $\begin{array}{l}2.6 \\
0.8\end{array}$ & $\begin{array}{l}2.7 \\
16.8\end{array}$ & $\begin{array}{l}2.6 \\
3.0\end{array}$ & $\begin{array}{l}3.2 . \\
5.2 \\
.\end{array}$ & 3 & 3 & 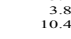 & $\begin{array}{l}3.7 \\
22.8\end{array}$ & $\begin{array}{l}3.7 \\
29.5\end{array}$ & $\begin{array}{r}3.6 \\
36.4\end{array}$ & $\begin{array}{r}3.5 \\
41.0\end{array}$ & $\begin{array}{l}3.5 \\
45.7\end{array}$ & $\begin{array}{l}3.4 \\
40.0\end{array}$ & $\begin{array}{c}3 \\
42 \\
42\end{array}$ & & $\begin{array}{r}2.0 \\
44.2\end{array}$ & $\begin{array}{r}1.6 \\
49.0\end{array}$ & $\begin{array}{l}11.6 \\
56.0\end{array}$ & $\begin{array}{c}1.5 \\
61.4\end{array}$ & $\begin{array}{r}1.5 \\
67.6\end{array}$ & $\begin{array}{r}0.8 \\
74.6 \\
-10\end{array}$ & $\begin{array}{l}3.2 \\
14.2\end{array}$ & 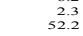 \\
\hline 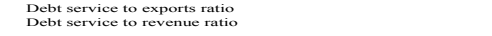 & $\begin{array}{l}9.1 \\
11.2 \\
\text { 1. }\end{array}$ & $\begin{array}{l}13.0 \\
17.1\end{array}$ & $\begin{array}{c}8.0 \\
10.5\end{array}$ & 9. & 9 & $8:$ & ${ }_{8.1}^{6.7}-10$ & $\begin{array}{l}7.4 \\
8.7\end{array}$ & $\begin{array}{l}7.5 \\
8.7\end{array}$ & $\begin{array}{l}7.7 \\
8.7\end{array}$ & 8.6 & 8.4 & 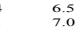 & $\frac{6}{6}$ & 6.4 & $\begin{array}{l}5.6 \\
5.9\end{array}$ & $\begin{array}{l}5.4 \\
5.6\end{array}$ & $\begin{array}{c}5.4 \\
5.5\end{array}$ & $\begin{array}{l}5.3 \\
5.3\end{array}$ & $\begin{array}{l}5.1 \\
5.1\end{array}$ & $\begin{array}{l}5.0 \\
5.0\end{array}$ & $\begin{array}{c}8.1 \\
10.1\end{array}$ & $\begin{array}{l}5.9 \\
6.2\end{array}$ \\
\hline \multicolumn{24}{|l|}{$\begin{array}{l}\text { Arter HIPC assistance 6/ } \\
\text { Total }\end{array}$} \\
\hline $\begin{array}{l}\text { Total } \\
\text { Existing debt } 2 / \\
\text { Multiliateral }\end{array}$ & $\begin{array}{l}58.5 \\
57.7 \\
49.7\end{array}$ & $\begin{array}{l}76.3 \\
59.4 \\
50.2\end{array}$ & $\begin{array}{l}54.5 \\
51.0 \\
46.3\end{array}$ & $\begin{array}{l}48 . \\
43 . \\
35 .\end{array}$ & $\begin{array}{l}5.5 \\
48 \\
40\end{array}$ & $\begin{array}{c}62 . \\
53 \\
45\end{array}$ & $\begin{array}{l}64.3 \\
54.6 \\
46.1\end{array}$ & $\begin{array}{l}75.9 \\
53.9 \\
45.4\end{array}$ & $\begin{array}{l}82.4 \\
53.6 \\
45.2\end{array}$ & $\begin{array}{l}90.2 \\
54.4 \\
46.5\end{array}$ & $\begin{array}{l}95.4 \\
54.9 \\
47.2\end{array}$ & $\begin{array}{l}98.7 \\
5.8 \\
46.3\end{array}$ & $\begin{array}{l}92.5 \\
52.4 \\
4.5\end{array}$ & $\begin{array}{l}92 \\
50 \\
44\end{array}$ & & $\begin{array}{l}92.2 \\
48.0 \\
43.2\end{array}$ & $\begin{array}{l}\begin{array}{l}94.9 \\
4.9 \\
42.5\end{array} \\
4.5\end{array}$ & $\begin{array}{r}101.1 \\
45.0 \\
41.8\end{array}$ & $\begin{array}{r}105.7 \\
44.4 \\
41.1\end{array}$ & $\begin{array}{l}\begin{array}{l}110.8 \\
43.2 \\
39.9\end{array} \\
39.9\end{array}$ & $\begin{array}{c}116.4 \\
41.8 \\
38.7\end{array}$ & $\begin{array}{l}6.9 .9 \\
53.0 \\
45.7\end{array}$ & $\begin{aligned} \begin{array}{r}100.0 \\
48.0 \\
43.0\end{array} & \end{aligned}$ \\
\hline $\begin{array}{l}\text { World Bank Group } \\
\text { IMF } 3 \text {, }\end{array}$ & $\begin{aligned} 17.3 \\
5.0 \\
25.4\end{aligned}$ & $\begin{array}{l}11.6 \\
17.0 \\
257\end{array}$ & $\begin{array}{l}18.5 \\
0.0 \\
250\end{array}$ & $\begin{array}{l}3 . \\
0.5\end{array}$ & $\begin{aligned} 14 . \\
0 .\end{aligned}$ & $\begin{aligned} 20 \\
0 \\
25\end{aligned}$ & $\begin{array}{l}19.9 \\
0.0 \\
24.8\end{array}$ & $\begin{array}{l}19.8 \\
0.0 \\
24.3\end{array}$ & $\begin{array}{l}19.7 \\
0.0\end{array}$ & $\begin{array}{l}20.9 \\
0.0 \\
22.3\end{array}$ & $\begin{array}{l}22.2 \\
0.0 \\
23.7\end{array}$ & $\begin{array}{l}22.3 \\
0.0 \\
22.7\end{array}$ & $\begin{array}{l}22.2 \\
0.0 \\
220\end{array}$ & $\begin{array}{r}22 \\
0 \\
20\end{array}$ & & $\begin{array}{l}21.9 \\
0.0 \\
200\end{array}$ & $\begin{array}{l}21.7 \\
0.0 \\
10 .\end{array}$ & $\begin{array}{l}21.6 \\
0.0 \\
100\end{array}$ & $\begin{array}{l}21.4 \\
0.0 \\
11.5\end{array}$ & $\begin{array}{l}21.3 \\
0.0 \\
11.4\end{array}$ & $\begin{array}{l}20.8 \\
0.0\end{array}$ & $\begin{array}{l}17.1 \\
2.2 \\
25.1\end{array}$ & $\begin{array}{l}21.7 \\
0.0 \\
20.1\end{array}$ \\
\hline 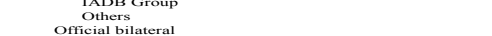 & $\begin{array}{l}25.4 \\
2.0 \\
7.9\end{array}$ & $\begin{array}{l}25.7 \\
2.0 \\
3.3\end{array}$ & $\begin{array}{c}25.9 \\
1.9 \\
4.7\end{array}$ & $\begin{array}{c}25 . \\
0 . \\
7.3\end{array}$ & $\begin{array}{c}25 . \\
0 . \\
8\end{array}$ & $\begin{array}{r}25 . \\
0 \\
8\end{array}$ & $\begin{array}{r}2.8 \\
1.3 \\
8.5\end{array}$ & $\begin{array}{l}24.3 \\
1.3 \\
8.4\end{array}$ & $\begin{array}{r}2.2 \\
1.3 \\
8.4\end{array}$ & $\begin{array}{l}24.3 \\
1.3 \\
7.9\end{array}$ & $\begin{array}{r}3.3 .3 \\
1.3 \\
7.7\end{array}$ & $\begin{array}{r}2.2 .3 \\
1.3 \\
7.4\end{array}$ & $\begin{array}{r}2.2 .0 \\
1.3 \\
7.0\end{array}$ & $\begin{array}{r}20 \\
1 \\
6 \\
6\end{array}$ & $\begin{array}{l}1.3 \\
0.4 \\
6.4 \\
0\end{array}$ & $\begin{array}{r}20.0 \\
1.3 \\
4.8\end{array}$ & $\begin{array}{r}1.6 .3 \\
3.4 \\
3.4\end{array}$ & $\begin{array}{l}1.0 \\
1.2 \\
3.2\end{array}$ & $\begin{aligned} 18.5 \\
1.2 \\
3.3\end{aligned}$ & $\begin{array}{l}1,4 \\
1.2 \\
3.3\end{array}$ & $\begin{array}{r}1.7 \\
1.2 \\
3.1\end{array}$ & $\begin{array}{l}25.1 \\
1.3 \\
7.3\end{array}$ & $\begin{array}{l}20.1 \\
1.3\end{array}$ \\
\hline 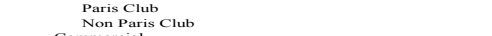 & $\begin{array}{l}5.3 \\
2.6\end{array}$ & $\begin{array}{l}1.1 \\
2.2\end{array}$ & $\frac{2.5}{2.2} \mathrm{r}-\mathrm{l} \mathrm{l}$ & 5.2. & $\frac{5}{2}$. & $\frac{5}{2}$ & 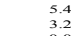 & $\begin{array}{l}5.3 \\
3.1\end{array}$ & $\begin{array}{c}5.3 \\
3.1 \\
3.1\end{array}$ & $\begin{array}{l}4.9 \\
3.0\end{array}$ & $\begin{array}{l}4.7 \\
3.0\end{array}$ & $\begin{array}{l}4.5 \\
2.9 \\
\end{array}$ & $\begin{array}{l}4.1 \\
2.8 \\
-1\end{array}$ & $\frac{3}{2}$ & & $\begin{array}{l}3.1 \\
1.7\end{array}$ & $\begin{array}{c}2.1 \\
1.3 \\
1.3\end{array}$ & $\begin{array}{l}1.9 \\
1.3\end{array}$ & $\begin{array}{c}2.0 \\
1.3 \\
1.3\end{array}$ & $\begin{array}{c}2.1 \\
1.2 \\
1.2\end{array}$ & $\begin{array}{l}2.4 \\
0.7\end{array}$ & $\begin{array}{l}4.6 \\
2.7\end{array}$ & $\begin{array}{l}3.1 \\
1.9 \\
1.9\end{array}$ \\
\hline $\begin{array}{l}\text { Commercial } \\
\text { New debt 4/ }\end{array}$ & $\begin{array}{l}0.0 \\
0.8\end{array}$ & $\begin{array}{l}5.0 \\
16.8\end{array}$ & $\begin{array}{l}0.0 \\
3.5 \\
-5\end{array}$ & $\begin{array}{l}0.4 \\
5.2 \\
.\end{array}$ & . & $\begin{array}{l}0 . \\
0.9\end{array}$ & $\begin{array}{l}0.0 \\
9.7\end{array}$ & $\begin{array}{c}0.0 \\
22.1\end{array}$ & $\begin{array}{l}0.0 \\
28.8\end{array}$ & $\begin{array}{l}0.0 \\
35.8\end{array}$ & $\begin{array}{r}0.0 \\
40.5\end{array}$ & $\begin{array}{c}0.0 \\
44.9\end{array}$ & $\begin{array}{r}0.0 \\
40.0\end{array}$ & $\begin{array}{c}0 \\
42 \\
42\end{array}$ & & $\begin{array}{r}0.0 \\
44.2\end{array}$ & $\begin{array}{c}0.0 \\
49.0\end{array}$ & $\begin{array}{c}0.0 \\
56.0\end{array}$ & $\begin{array}{c}0.0 \\
61.4\end{array}$ & $\begin{array}{c}0.0 \\
67.6\end{array}$ & $\begin{array}{r}0.0 \\
74.6\end{array}$ & $\begin{array}{c}0.0 \\
13.9\end{array}$ & $\begin{array}{rl}0.0 & 0.0\end{array}$ \\
\hline 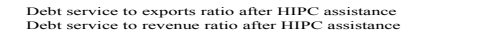 & $\begin{array}{l}9.3 \\
11.4\end{array}$ & $\begin{array}{l}11.0 \\
14.6\end{array}$ & 9.1 .4 & 5.4. & 7. & 6 & 6.5 & $\begin{array}{l}6.9 \\
8.2\end{array}$ & $\begin{array}{l}7.1 \\
8.2\end{array}$ & 8.2 & $\begin{array}{l}7.2 \\
8.0\end{array}$ & $\begin{array}{l}6.9 \\
7.6\end{array}$ & $\begin{array}{c}6.1 \\
6.5\end{array}$ & $\begin{array}{c}5 \\
6\end{array}$ & $\begin{array}{l}5.7 \\
6.0\end{array}$ & $\begin{array}{c}5.3 \\
5.5\end{array}$ & $\begin{array}{l}5.1 \\
5.2\end{array}$ & $\begin{array}{c}5.0 \\
5.1\end{array}$ & $\begin{array}{c}4.9 \\
5.0\end{array}$ & $\begin{array}{l}4.8 \\
4.8\end{array}$ & $\begin{array}{l}4.7 \\
4.6\end{array}$ & $\begin{array}{l}7.3 \\
9.1\end{array}$ & $\begin{array}{c}5.6 \\
5.8\end{array}$ \\
\hline $\begin{array}{l}\text { Reduction in debt service as a result of } \\
\text { HIPC Initiative assistance } 7 /\end{array}$ & $\ldots$ & 13.3 & 6.5 & 15. & 11. & s. & 5.0 & 5.2 & s.o & 5.6 & 5.9 & 6.4 & 6.3 & .3 & 5.2 & 5.4 & 6.6 & 7.6 & 7.8 & 8.o & 7.8 & 8.o & 6.7 \\
\hline \multicolumn{24}{|l|}{$\begin{array}{l}\text { Affer HIPC and MDRI assistance 8/ } \\
\text { Total }\end{array}$} \\
\hline 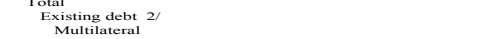 & $\begin{array}{l}58.5 \\
57.7 \\
49.7\end{array}$ & 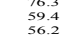 & $\begin{array}{l}5.1 \\
51.0 \\
46.3\end{array}$ & 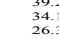 & $\begin{array}{l}34 . \\
36 . \\
26 .\end{array}$ & $\begin{array}{l}34 \\
34 \\
25\end{array}$ & 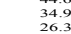 & $\begin{array}{lll}56.3 \\
34.3 \\
25.8\end{array}$ & $\begin{array}{c}2.9 \\
34.1 \\
25.8\end{array}$ & $\begin{array}{l}33.9 \\
26.1\end{array}$ & $\begin{array}{l}33.9 \\
25.4 \\
25.8\end{array}$ & $\begin{array}{l}31.1 \\
22.2 \\
24.7\end{array}$ & 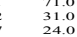 & $\begin{array}{l}19 \\
29 \\
22\end{array}$ & & $\begin{array}{l}26.8 \\
2.8 \\
22.0\end{array}$ & $\begin{array}{l}23.9 \\
22.9 \\
21.5\end{array}$ & $\begin{array}{l}78.2 \\
242.2 \\
20.9\end{array}$ & 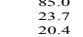 & $\begin{array}{c}20.2 \\
22.6 \\
19.3\end{array}$ & $\begin{array}{l}22.6 \\
22.0 \\
11.9\end{array}$ & 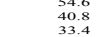 & $\begin{array}{l}27.0 \\
22.0 \\
22.1\end{array}$ \\
\hline $\begin{array}{l}\text { World Bank Group } \\
\text { IMF } 3 \text {, } \\
\text { MPB? }\end{array}$ & $\begin{array}{l}17.3 \\
5.0 \\
250\end{array}$ & $\begin{array}{c}11,6 \\
17.0 \\
17.0\end{array}$ & $\begin{array}{c}18.5 \\
0.0 \\
258\end{array}$ & $\begin{array}{ccc}0 . \\
0.4 \\
25\end{array}$ & $\begin{array}{c}0 . \\
0 . \\
2 .\end{array}$ & $\begin{array}{c}\mathrm{O} \\
\mathrm{O} \\
2 \mathrm{~S}\end{array}$ & $\begin{array}{c}0.2 \\
0.0 \\
2.8\end{array}$ & 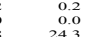 & 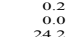 & 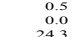 & $\begin{array}{c}0.7 \\
0.0 \\
2.3\end{array}$ & $\begin{array}{c}0.7 \\
0.0 \\
2.2\end{array}$ & $\begin{array}{c}0.7 \\
0.0 \\
2.0\end{array}$ & $\begin{array}{ccc}\mathrm{o} \\
\mathrm{o} \\
20\end{array}$ & & $\begin{array}{c}0.7 \\
0.0 \\
200\end{array}$ & $\begin{array}{c}0.7 \\
0.0 \\
1.0\end{array}$ & $\begin{array}{c}0.7 \\
0.0 \\
10.0\end{array}$ & $\begin{array}{c}0.7 \\
0.0 \\
10.5\end{array}$ & $\begin{array}{c}0.7 \\
0.0 \\
1.3\end{array}$ & $\begin{array}{c}1.0 \\
0.0 \\
1.0\end{array}$ & $\frac{4.9}{2.2}$ & $\begin{array}{c}0.7 \\
0.0 \\
20 .\end{array}$ \\
\hline $\begin{array}{c}\text { IADB Group } \\
\text { Others } \\
\text { Official bilateral }\end{array}$ & $\begin{array}{c}2.0 \\
7.9 \\
2\end{array}$ & $\begin{array}{l}2.0 \\
3.3 \\
3\end{array}$ & $\begin{array}{ll}2.9 \\
4.7\end{array}$ & 0. & o. & $\begin{array}{c}25 \\
0 \\
8\end{array}$ & $\begin{array}{c}1.3 \\
8.5 \\
8.5\end{array}$ & $\begin{array}{l}24.3 \\
1.4 \\
8.4\end{array}$ & $\begin{array}{c}2.2 \\
1.3 \\
8.4\end{array}$ & $\begin{array}{c}1.3 \\
7.9 \\
7.9\end{array}$ & $\begin{array}{c}3.3 \\
7.7 \\
\text {. }\end{array}$ & $\begin{array}{l}2.3 \\
7.4\end{array}$ & $\begin{array}{c}2.3 \\
7.0\end{array}$ & 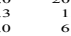 & & $\begin{array}{r}1.3 \\
4.8\end{array}$ & $\begin{aligned} 10.6 \\
1.3 \\
3.4\end{aligned}$ & $\begin{array}{c}19.0 \\
1.2 \\
3.2\end{array}$ & $\begin{array}{c}1.2 \\
1.3 \\
3.3\end{array}$ & $\begin{array}{c}17.4 \\
1.2 \\
3.3\end{array}$ & $\begin{array}{rl}1 & 0.7 \\
3.2 \\
3.1\end{array}$ & $\begin{array}{c}1.3 \\
7.3 \\
7.3\end{array}$ & $\begin{array}{c}20.1 \\
1.3 \\
5.0\end{array}$ \\
\hline $\begin{array}{l}\text { Commercial } \\
\text { New debt } 4 /\end{array}$ & $\begin{array}{l}.0 .0 \\
0.8\end{array}$ & $\begin{array}{c}0.0 \\
16.8\end{array}$ & $\begin{array}{c}0.0 .0 \\
3.5\end{array}$ & o.t. & o. & $\stackrel{0 .}{9}$. & $\begin{array}{l}0.0 \\
9.7 \\
9\end{array}$ & 22.1 & $\begin{array}{c}0.0 \\
28.8\end{array}$ & $\begin{array}{l}0.0 \\
35.8\end{array}$ & $\begin{array}{c}0.0 \\
40.5\end{array}$ & 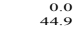 & $\begin{array}{c}0.0 \\
40.0\end{array}$ & ${ }_{42}^{0}$ & & $\begin{array}{c}0.0 \\
44.2\end{array}$ & $\begin{array}{c}0.0 \\
49.0\end{array}$ & $\begin{array}{c}0.0 \\
56.0\end{array}$ & $\begin{array}{l}0.0 \\
61.4\end{array}$ & $\begin{array}{c}0.0 \\
67.6\end{array}$ & $\begin{array}{l}0.0 \\
74.6\end{array}$ & $\begin{array}{c}0.0 \\
13.9\end{array}$ & $\begin{array}{cccc}0.0 \\
52.0\end{array}$ \\
\hline 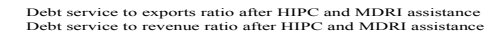 & $\begin{array}{l}9.3 \\
11.4\end{array}$ & 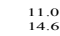 & $\begin{array}{l}7.1 \\
9.4\end{array}$ & 4.: & s. & $\stackrel{4}{5}$. & $\begin{array}{l}4.3 \\
5.2\end{array}$ & $\begin{array}{c}5.1 \\
6.1\end{array}$ & $\begin{array}{l}5.4 \\
6.2\end{array}$ & $\begin{array}{l}5.6 \\
6.4\end{array}$ & $\begin{array}{l}5.6 \\
6.2\end{array}$ & 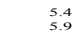 & $\begin{array}{l}4.7 \\
5.0\end{array}$ & .0 & $\begin{array}{l}4.4 \\
4.7\end{array}$ & $\begin{array}{l}4.1 \\
4.3\end{array}$ & $\begin{array}{l}3.9 \\
4.1\end{array}$ & $\begin{array}{l}4.0 \\
4.1\end{array}$ & $\begin{array}{l}3.9 \\
4.0\end{array}$ & $\begin{array}{l}3.9 \\
3.9\end{array}$ & $\begin{array}{l}3.9 \\
3.9\end{array}$ & $\begin{array}{l}6.2 \\
7.7\end{array}$ & ${ }_{4.6}^{4.4}$ \\
\hline \multicolumn{24}{|l|}{$\begin{array}{l}\text { After additional bilateral relier beyond enh? } \\
\text { Total }\end{array}$} \\
\hline $\begin{array}{l}\text { Total } \\
\text { Existing debt } 2 /\end{array}$ & $\begin{array}{c}58.5 \\
57.7\end{array}$ & $\begin{array}{c}76.3 \\
59.4 \\
4\end{array}$ & $\begin{array}{l}52.2 \\
48.7\end{array}$ & $\begin{array}{l}34.4 \\
28.8\end{array}$ & $\begin{array}{l}35 . \\
28 .\end{array}$ & $\begin{array}{l}37 . \\
28 . \\
.\end{array}$ & 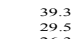 & $\begin{array}{l}51.0 \\
29.0 \\
290\end{array}$ & $\begin{array}{l}57.6 \\
28.8\end{array}$ & $\begin{array}{c}62.9 \\
29.1\end{array}$ & $\begin{array}{l}69.2 \\
28.7 \\
-\end{array}$ & $\begin{array}{l}72.6 \\
27.7 \\
-\end{array}$ & 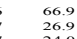 & $\begin{array}{c}67 \\
25 \\
2\end{array}$ & & $\begin{array}{l}67.9 \\
23.7\end{array}$ & 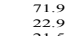 & 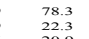 & $\begin{array}{l}83.0 \\
21.7 \\
21.7\end{array}$ & 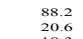 & 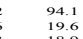 & $\begin{array}{c}50.7 \\
36.9\end{array}$ & 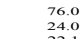 \\
\hline $\begin{array}{l}\text { Muttilateral biteral } \\
\text { Official bilaris } \\
\text { Paris Club }\end{array}$ & $\begin{array}{l}49.7 \\
7.9 \\
5.3\end{array}$ & $\begin{array}{r}5.2 \\
3.3 \\
1.1\end{array}$ & $\begin{array}{r}46.3 \\
2.4 \\
0.1\end{array}$ & $\begin{array}{c}26 . \\
2 . \\
0.4\end{array}$ & $\begin{array}{c}26 . \\
2 . \\
0 .\end{array}$ & $\begin{array}{c}25 . \\
2 . \\
0 .\end{array}$ & $\begin{array}{r}26.3 \\
3.2 \\
0.0\end{array}$ & $\begin{array}{r}\begin{array}{r}5.8 \\
3.1 \\
0.0\end{array} \\
0.0\end{array}$ & $\begin{array}{r}\begin{array}{r}5.8 \\
3.1 \\
0.0\end{array} \\
0.0\end{array}$ & $\begin{array}{r}2.6 .1 \\
3.0 \\
0.0\end{array}$ & $\begin{array}{r}25.8 \\
3.0 \\
0.0\end{array}$ & $\begin{array}{r}2.7 \\
2.9 \\
0.0\end{array}$ & $\begin{array}{r}24.0 \\
2.9 \\
0.0\end{array}$ & $\begin{array}{c}22 \\
2 \\
0\end{array}$ & & $\begin{array}{r}22.0 \\
1.7 \\
0.0\end{array}$ & $\begin{array}{r}21.5 \\
1.3 \\
0.0\end{array}$ & $\begin{array}{r}20.9 \\
1.3 \\
0.0\end{array}$ & $\begin{array}{r}20.4 \\
1.3 \\
0.0\end{array}$ & $\begin{array}{c}19.3 \\
1.2 \\
0.0\end{array}$ & $\begin{array}{r}18.9 \\
0.7 \\
0.0\end{array}$ & 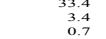 & $\begin{array}{r}22.1 \\
1.9 \\
0.0\end{array}$ \\
\hline $\begin{array}{l}\text { Non arais Club } \\
\text { Conmerercial } \\
\text { New debt } 4 /\end{array}$ & $\begin{array}{l}2.6 \\
0.0 \\
0.8\end{array}$ & $\begin{aligned} 2.2 \\
0.0 \\
10.8\end{aligned}$ & $\begin{array}{l}2.2 \\
0.0 \\
3.5\end{array}$ & $\begin{array}{l}2 . \\
0 . \\
5.2\end{array}$ & $\begin{array}{l}2 . \\
0 . \\
7 .\end{array}$ & $\begin{array}{l}2 . \\
0 . \\
9\end{array}$ & $\begin{array}{l}3.2 \\
0.0 \\
9.7\end{array}$ & $\begin{array}{r}3.1 \\
\text { o.o } \\
2.2 .1\end{array}$ & $\begin{array}{r}3.1 \\
\text { 3.0 } \\
28.8\end{array}$ & $\begin{aligned} 3.0 \\
\text { 3.o } \\
35.8\end{aligned}$ & $\begin{array}{r}3.0 \\
3.0 \\
40.5\end{array}$ & $\begin{array}{r}2.9 \\
0.9 \\
44.9\end{array}$ & $\begin{array}{r}2.8 \\
2.0 \\
40.0\end{array}$ & $\begin{aligned} 2 \\
0 \\
42\end{aligned}$ & & $\begin{array}{r}1.7 \\
0.0 \\
4.2\end{array}$ & $\begin{aligned} 1.3 \\
1.3 \\
0.0 \\
49.0\end{aligned}$ & $\begin{array}{c}1.3 \\
1.3 \\
\text { o.o } \\
56.0\end{array}$ & $\begin{array}{r}1.3 \\
1.3 \\
0.0 \\
6.4\end{array}$ & $\begin{aligned} 1.2 \\
1.2 \\
0.0 \\
67.6\end{aligned}$ & $\begin{aligned} 0.7 \\
0.7 \\
0.0 \\
7.6\end{aligned}$ & $\begin{array}{l}2.7 \\
\text { a.0. } \\
13.9\end{array}$ & $\begin{aligned} 1.9 \\
0.0 \\
\text { o.o }\end{aligned}$ \\
\hline $\begin{array}{l}\text { Reduction in debt service as a result of } \\
\text { MDRR assistance } \\
\text { Additional bilateral relief beyond HIPC }\end{array}$ & $\begin{array}{c}0.0 \\
0.0\end{array}$ & $\begin{array}{c}0.0 \\
0.0\end{array}$ & 0.0 & 9.3 & $\begin{array}{l}14 . \\
5\end{array}$ & ${ }_{5}^{19}$. & $\begin{array}{c}19.7 \\
5.3\end{array}$ & $\begin{array}{c}19.6 \\
5.3\end{array}$ & $\begin{array}{c}19.5 \\
5.3\end{array}$ & $\begin{array}{c}20.5 \\
4.8\end{array}$ & $\begin{array}{r}21.4 \\
4.7\end{array}$ & $\begin{array}{r}21.6 \\
4.5\end{array}$ & $\begin{array}{r}21.4 \\
4.1\end{array}$ & 21 & 1.3. & $\begin{array}{l}21.2 \\
3.1\end{array}$ & $\begin{array}{c}21.0 \\
2.1\end{array}$ & 20.9 & $\begin{array}{c}20.7 \\
2.0\end{array}$ & $\begin{array}{c}20.6 \\
2.1\end{array}$ & $\frac{19.8}{2.4}$ & $\frac{12.2}{3.9}$ & $\begin{array}{r}21.0 \\
3.0\end{array}$ \\
\hline 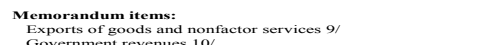 & $\begin{array}{l}631.3 \\
631\end{array}$ & \begin{tabular}{l}
601.1 \\
\hdashline
\end{tabular} & 783.8 & 824. & goo. & 970. & 1, 1,031. & $1,096.2$ & & $1,246.2$ & $1,331.2$ & $1,423.1$ & $\begin{array}{l}1,522.7 \\
\end{array}$ & $\begin{array}{ll}7 & 71,630\end{array}$ & & 1,747.6 & $1,874.6$ & & $2,162.1$ & $2,324.8$ & $2,501.7$ & 932.4 & 853.1 \\
\hline & & & & & & & 858.0 & 930.7 & $1,008.9$ & $1,098.2$ & $1,194.9$ & $1,299.4$ & $\begin{array}{l}4,412.5 \\
+\end{array}$ & $\begin{array}{ll}5 & 1,534\end{array}$ & & $1,666.8$ & $1,809.6$ & $1,963.8$ & $2,130.4$ & $2,310.2$ & $2,504.5$ & 766.1 & 782.7 \\
\hline
\end{tabular}

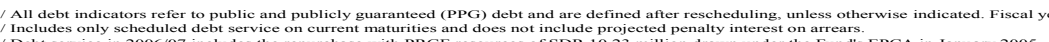

4 Reflects debt service on the projected borrowing needed to close the gap. Debt service in $2006 / 17$ includes the repurchase with PRGF resources of SDR 10.23 million previously drawn under the Fund's EPCA in October 2005

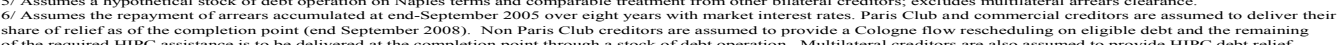

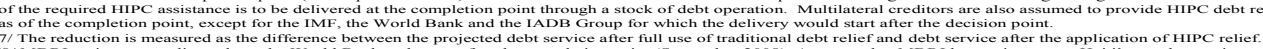

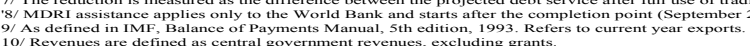

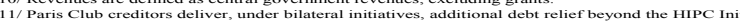




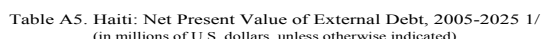

\begin{tabular}{|c|c|c|c|c|c|c|c|c|c|c|c|c|c|c|c|c|c|c|c|c|c|c|c|}
\hline & 2004/05 & $2005 / 06$ & 2006/07 & 2007/08 & $2008 / 09$ & $2009 / 10$ & $2010 / 11$ & $2011 / 12$ & 2012/13 & 2013/14 & 2014/15 & $2015 / 16$ & 2016/17 & $2017 / 18$ & $2018 / 19$ & 2019/20 & 2020/21 & $2021 / 22$ & 2022/23 & $2023 / 24$ & 2024/25 & 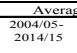 & $\begin{array}{ll}20151516- \\
2024 / 25\end{array}$ \\
\hline - After traditional debt-relier $2 / 3 /$ & & & & & & & & & & & & & & & & & & & & & & & \\
\hline $\begin{array}{l}\text { NPV or outsanding debt } \\
\text { Nofrifial bitateral and commercial }\end{array}$ & $\begin{array}{c}\substack{8855 \\
134.5} \\
134.8\end{array}$ & $\begin{array}{l}869.2 \\
134.1\end{array}$ & $\begin{array}{c}836.0 \\
133.4\end{array}$ & $\begin{array}{c}817.0 \\
172.5\end{array}$ & $\begin{array}{c}796.0 \\
130.7\end{array}$ & $\begin{array}{c}773.0 \\
128.5 \\
1.5\end{array}$ & $\begin{array}{l}749.4 \\
142.2 \\
12.2\end{array}$ & $\begin{array}{l}724.8 \\
123.0 \\
120\end{array}$ & $\begin{array}{c}699.5 \\
119.4\end{array}$ & $\begin{array}{l}673.6 \\
671.0 \\
11.0\end{array}$ & $\begin{array}{c}\substack{64.9 \\
12.9} \\
12.2\end{array}$ & $\begin{array}{l}614.2 \\
614.0 \\
108.0\end{array}$ & $\begin{array}{l}58.8 \\
58.2 \\
103.3\end{array}$ & $\begin{array}{l}1,114.4 \\
550.6 \\
98.1\end{array}$ & $\begin{array}{l}1,815.5 \\
519.9 \\
94.3\end{array}$ & $\begin{array}{l}1.920 .2 \\
490.2 \\
91.4\end{array}$ & $\begin{array}{l}2,022.5 \\
460.0 \\
88.6\end{array}$ & $\begin{array}{l}2,116.9 \\
48.3 \\
84.7\end{array}$ & $\begin{aligned} & \begin{array}{r}2,199.7 \\
395.6 \\
80.2\end{array} 0 \\
& 0\end{aligned}$ & $\begin{array}{l}2,280.6 \\
36.4 \\
75.2\end{array}$ & $\begin{array}{l}2.349 .9 \\
329.3 \\
70.3\end{array}$ & $\begin{array}{l}1,155.8 \\
709.9 \\
126.4\end{array}$ & $\begin{array}{l}9.959 .1 \\
89.3 \\
89.4\end{array}$ \\
\hline $\begin{array}{l}\text { Paris Club } \\
\text { Other official bilateral }\end{array}$ & $\begin{array}{c}98.4 \\
36.4\end{array}$ & $\begin{array}{c}3.6 .6 \\
98.6 \\
35.6\end{array}$ & $\begin{array}{c}98.7 \\
34.7\end{array}$ & $\begin{array}{c}98.7 \\
93.8\end{array}$ & $\begin{array}{c}98.2 \\
92.5 \\
32.5\end{array}$ & $\begin{array}{c}97.6 \\
30.9\end{array}$ & $\begin{array}{l}97.0 \\
29.2 \\
29\end{array}$ & $\begin{array}{c}96.1 \\
20.9 \\
20.9\end{array} \mathrm{~V} \mathrm{~V}$ & $\frac{94.9}{24.5}$ & $\begin{array}{c}93.9 \\
22.1\end{array}$ & $\begin{array}{c}92.6 \\
19.6\end{array}$ & $\begin{array}{l}90.9 \\
17.1\end{array}$ & $\begin{array}{l}88.9 \\
88.9 \\
14.4\end{array}$ & $\begin{array}{c}86.4 \\
11.4 \\
1.1\end{array}$ & 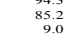 & $\begin{array}{l}91.4 \\
84.0 \\
7.5\end{array}$ & $\begin{array}{c}88.2 \\
82.4 \\
6.2\end{array}$ & 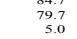 & $\begin{array}{c}50.5 \\
76.5 \\
3.7\end{array}$ & $\begin{array}{c}72.2 \\
72.8 \\
2.4\end{array}$ & $\begin{array}{c}68.6 \\
1.7\end{array}$ & $\begin{array}{r}126.4 \\
96.8 \\
29.7\end{array}$ & $\begin{array}{l}88.4 \\
81.5 \\
7.9\end{array}$ \\
\hline $\begin{array}{l}\text { Commercial } \\
\text { Multiateral } \\
\text { NPV of new borrowing }\end{array}$ & $\begin{array}{r}0.0 \\
750.6 \\
0.0\end{array}$ & $\begin{aligned} 0.0 \\
735.1 \\
45.4\end{aligned}$ & $\begin{array}{l}0.0 \\
702.7 \\
126.1\end{array}$ & $\begin{array}{l}0.0 \\
684.5 \\
198.7\end{array}$ & $\begin{array}{c}0.0 \\
65.2 \\
287.9\end{array}$ & $\begin{array}{l}0.0 \\
644.5 \\
383.7\end{array}$ & $\begin{aligned} 0.0 \\
623.2 \\
477.7\end{aligned}$ & $\begin{array}{l}0.0 \\
60.1 .8 \\
564.8\end{array}$ & $\begin{array}{l}0.0 \\
580.1 \\
626.4\end{array}$ & $\begin{array}{l}0.0 \\
557.6 \\
724.0\end{array}$ & $\begin{aligned} 0.0 \\
532.7 \\
828.2\end{aligned}$ & $\begin{aligned} 0.0 \\
506.2 \\
934.2\end{aligned}$ & $\begin{aligned} 0.0 \\
479.9 \\
1040.2\end{aligned}$ & $\begin{array}{l}0.0 \\
45.4 \\
1163.8\end{array}$ & $\begin{aligned} 0.0 \\
425.6 \\
1295.6\end{aligned}$ & $\begin{array}{r}0.0 \\
398.8 \\
1430.0\end{array}$ & $\begin{aligned} 0.0 \\
371.4 \\
152.4\end{aligned}$ & $\begin{array}{r}0.0 \\
343.7 \\
1688.6\end{array}$ & $\begin{aligned} 0.0 \\
315.4 \\
1804.4\end{aligned}$ & $\begin{array}{r}0.0 \\
287.2 \\
198.2\end{array}$ & $\begin{aligned} \begin{array}{r}0.0 \\
259.0 \\
2020.6\end{array} & 0\end{aligned}$ & $\begin{aligned} \begin{array}{c}0.0 .0 \\
643.4 \\
385.9\end{array} & 0\end{aligned}$ & $\begin{array}{r}0.0 \\
38.9 \\
1,485.8\end{array}$ \\
\hline \multicolumn{24}{|l|}{$\begin{array}{l}\text { Memorandum items: } \\
\text { NPV of debt-to-exports ratio (percent) 4/ }\end{array}$} \\
\hline $\begin{array}{l}\text { Tolat debb-to-exports ratio (percent) } 4 / \\
\text { Outstanding debt }\end{array}$ & $\begin{array}{l}168.6 \\
168.6\end{array}$ & $\begin{array}{l}157.8 \\
150.0\end{array}$ & $\begin{array}{l}150.3 \\
130.6\end{array}$ & $\begin{array}{l}146.0 \\
117.5\end{array}$ & $\begin{array}{l}142.6 \\
104.7\end{array}$ & 139.4 & 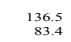 & $\begin{array}{l}131.4 \\
77.9\end{array}$ & 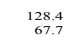 & 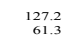 & $\begin{array}{c}125.9 \\
55.1\end{array}$ & $\begin{array}{l}124.0 \\
49.2\end{array}$ & $\begin{array}{r}121.7 \\
43.7\end{array}$ & $\begin{array}{l}120.2 \\
38.6\end{array}$ & $\begin{array}{l}{ }_{334.1}^{119.0} \\
34.1\end{array}$ & $\begin{array}{c}177.5 \\
30.0\end{array}$ & $\begin{array}{l}115.5 \\
26.3\end{array}$ & $\begin{array}{l}112.7 \\
22.8\end{array}$ & $\begin{array}{c}109.1 \\
19.6\end{array}$ & $\begin{array}{c}105.3 \\
16.7\end{array}$ & $\begin{array}{c}10.9 \\
14.1\end{array}$ & $\begin{array}{l}141.3 \\
100.6\end{array}$ & $\begin{array}{l}114.6 \\
29.5 \\
\end{array}$ \\
\hline $\begin{array}{c}\text { NPV of deb-to-reven } \\
\text { Tout debtats } \\
\text { Oustanding debt }\end{array}$ & $\frac{234.5}{234.5}$ & $\begin{array}{l}178.1 \\
169.3\end{array}$ & $\begin{array}{l}184.1 \\
160.0\end{array}$ & $\begin{array}{l}174.7 \\
140.5\end{array}$ & $\begin{array}{l}167.4 \\
123.0\end{array}$ & $\begin{array}{l}163.1 \\
109.0\end{array}$ & $\begin{array}{l}155.2 \\
94.8\end{array}$ & $\begin{array}{l}1488.2 \\
88.5\end{array}$ & $\begin{array}{l}142.5 \\
75.2\end{array}$ & 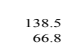 & $\begin{array}{c}134.1 \\
58.7\end{array}$ & $\begin{array}{l}129.6 \\
51.4\end{array}$ & $\begin{array}{l}124.9 \\
44.8\end{array}$ & $\begin{array}{l}121.4 \\
33.0\end{array}$ & $\begin{array}{l}118.3 \\
3.3 .9\end{array}$ & $\begin{array}{l}115.2 \\
29.4\end{array}$ & $\begin{array}{l}111.8 \\
25.4\end{array}$ & $\begin{array}{l}107.8 \\
21.8\end{array}$ & $\begin{array}{c}103.3 \\
11.6\end{array}$ & $\begin{array}{l}98.7 \\
15.7\end{array}$ & $\begin{array}{c}93.8 \\
13.1\end{array}$ & $\begin{array}{l}165.5 \\
119.6\end{array}$ & .3 .5 \\
\hline \multicolumn{24}{|c|}{ II. After conditional delivery of enhanced HIPC assistance $5 /$ /. } \\
\hline $\begin{array}{l}\text { NPV of total debt } \\
\text { NPV of outstanding debt }\end{array}$ & $\begin{array}{l}920.7 \\
920.7\end{array}$ & $\begin{array}{l}921.0 \\
875.6\end{array}$ & $\begin{array}{l}982.2 \\
856.2\end{array}$ & $\begin{array}{l}911.7 \\
713.1\end{array}$ & $\begin{array}{c}990.0 \\
702.1\end{array}$ & 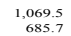 & 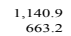 & $\begin{array}{c}1,1855.5 \\
638.7\end{array}$ & $\begin{array}{l}1,240.3 \\
613.9\end{array}$ & $\begin{array}{l}1,312.2 \\
58.2\end{array}$ & $\begin{array}{l}1,388.8 \\
500.6\end{array}$ & 1,465.4 31.2 & $\begin{array}{l}1,541.8 \\
501.5\end{array}$ & $\begin{array}{l}1,635.6 \\
47.9\end{array}$ & $\begin{array}{l}1,738.3 \\
424.7\end{array}$ & $\begin{array}{l}1,844.7 \\
44.8\end{array}-1$ & 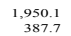 & $\begin{array}{l}2,048.8 \\
30.22\end{array}$ & $\begin{array}{l}2,136.3 \\
332.2\end{array}$ & $\frac{2,222.1}{304.0}$ & $\frac{2,296.5}{275.9}$ & 1.,096.6 70.7 & \\
\hline $\begin{array}{l}\text { Officiai bialateral and commercial } \\
\text { Paris club }\end{array}$ & $\begin{array}{l}182.2 \\
1455.7\end{array}$ & $\begin{array}{l}153.3 \\
123.6\end{array}$ & $\begin{array}{l}157.2 \\
128.3\end{array}$ & $\begin{array}{l}93.6 \\
65.4\end{array}$ & $\begin{array}{c}90.1 \\
63.0\end{array}$ & $\begin{array}{l}80.1 \\
60.3\end{array}$ & $\begin{array}{l}82.0 \\
57.6\end{array}$ & 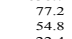 & $\begin{array}{l}72.3 \\
51.9\end{array}$ & $\begin{array}{c}67.3 \\
48.8\end{array}$ & $\begin{array}{c}62.5 \\
46.1\end{array}$ & $\begin{array}{l}53.6 \\
43.4\end{array}$ & $\begin{array}{c}52.8 \\
40.8\end{array}$ & $\begin{array}{l}48.3 \\
38.5 \\
\end{array}-\mathrm{l}$ & $\begin{array}{l}4.4 .1 \\
30.6\end{array}$ & $\begin{array}{c}44.3 \\
35.1\end{array}$ & $\begin{array}{l}39.7 \\
34.5\end{array}$ & $\begin{array}{l}38.3 \\
34.1\end{array}$ & $\begin{array}{l}36.7 \\
33.6\end{array}$ & $\begin{array}{c}35.0 \\
33.1\end{array}$ & $\begin{array}{l}33.5 \\
32.1\end{array}$ & 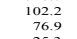 & 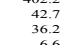 \\
\hline $\begin{array}{l}\text { OOhher official bilateral } \\
\text { Commercial }\end{array}$ & $\begin{array}{c}36.5 \\
0.0\end{array}$ & $\begin{array}{r}29.7 \\
0.0\end{array}$ & $\begin{array}{r}29.0 \\
0.0\end{array}$ & $\begin{array}{r}28.2 \\
0.0\end{array}$ & $\begin{array}{r}27.1 \\
0.0\end{array}$ & $\begin{array}{c}25.8 \\
0.0\end{array}$ & ${ }_{0.0}^{24.4}$ & $\begin{array}{c}22.4 \\
0.0\end{array}$ & ${ }^{20.4} 0.0$ & $\begin{array}{r}18.4 \\
0.0\end{array}$ & $\begin{array}{r}16.3 \\
0.0\end{array}$ & $\begin{array}{c}1.4 .2 \\
0.0\end{array}$ & $\begin{array}{l}12.0 \\
0.0\end{array}$ & $\begin{array}{l}9.8 \\
0.0\end{array}$ & $\begin{array}{l}7.5 \\
0.0\end{array}$ & $\begin{array}{l}6.2 \\
0.0\end{array}$ & $\begin{array}{l}5.2 \\
0.0\end{array}$ & $\begin{array}{l}4.1 \\
0.0\end{array}$ & $\begin{array}{l}3.1 \\
0.0\end{array}$ & $\begin{array}{l}2.0 \\
0.0\end{array}$ & $\begin{array}{l}1.4 \\
0.0\end{array}$ & $\begin{array}{c}25.3 \\
0.0\end{array}$ & $\begin{array}{l}6.6 \\
0.0\end{array}$ \\
\hline $\begin{array}{l}\text { Mutliateral } \\
\text { NPV of new borrowing }\end{array}$ & $\begin{array}{c}738.5 \\
0.0\end{array}$ & $\begin{array}{r}722.3 \\
45.4\end{array}$ & $\begin{array}{l}698.9 \\
126.1\end{array}$ & $\begin{array}{l}699.4 \\
198.7\end{array}$ & $\begin{array}{l}612.0 \\
287.9\end{array}$ & 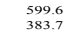 & 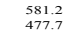 & 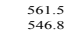 & 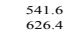 & $\begin{array}{c}521.0 \\
724.0\end{array}$ & $\begin{array}{l}488.1 \\
828.2\end{array}$ & $\begin{array}{l}473.5 \\
934.2\end{array}$ & $\begin{array}{l}448.7 \\
1080.2\end{array}$ & $\begin{array}{r}423.6 \\
1163.8\end{array}$ & $\begin{array}{r}399.6 \\
1295.6\end{array}$ & $\begin{array}{r}373.5 \\
1430.0\end{array}$ & $\begin{array}{r}344.9 \\
1562.4\end{array}$ & $\begin{array}{r}321.9 \\
1688.6\end{array}$ & $\begin{array}{c}295.4 \\
1854.1\end{array}$ & $\begin{array}{r}268.9 \\
198.2\end{array}$ & $\begin{array}{l}242.4 \\
2020.6\end{array}$ & $\begin{array}{l}608.6 \\
385.9\end{array}$ & 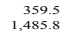 \\
\hline \multicolumn{24}{|c|}{ III. After unconditional delivery of enhanced HIPC assistance 6 / } \\
\hline $\begin{array}{l}\text { NPV of total debt } \\
\text { NPV of oustanding debt }\end{array}$ & $\begin{array}{l}787.9 \\
787.9\end{array}$ & $\begin{array}{c}798.4 \\
753.0\end{array}$ & $\begin{array}{c}856.9 \\
770.8\end{array}$ & $\begin{array}{l}911.7 \\
713.1\end{array}$ & $\begin{array}{c}990.0 \\
702.1\end{array}$ & $\begin{array}{l}1,069.5 \\
685.7\end{array}$ & 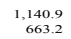 & $\frac{1,185.5}{638.7}$ & $\frac{1,240.3}{613.9}$ & $\begin{array}{l}1,312.2 \\
588.2\end{array}$ & $\begin{array}{l}1,388.8 \\
506.6\end{array}$ & 1,465.4 $1,41.2$ & $\begin{array}{l}1,541.8 \\
\text { sol.5 }\end{array}$ & $\begin{array}{l}1,635.6 \\
471.9\end{array}$ & $\begin{array}{l}1,738.3 \\
442.7\end{array}$ & $\begin{array}{l}1,844.7 \\
44.8\end{array}$ & 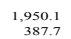 & 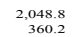 & $\begin{array}{l}2,136.3 \\
332.1\end{array}$ & $\frac{2,222.1}{304.0}$ & $2,296.5$ & 1,.067.0 & 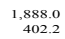 \\
\hline $\begin{array}{l}\text { Official bilateral and and comn } \\
\text { Paris lemb }\end{array}$ & $\begin{array}{c}11.4 \\
114.4 \\
83.6\end{array}$ & $\begin{array}{l}93.1 \\
93.1 \\
63.4\end{array}$ & $\begin{array}{l}94.1 \\
94.1 \\
65.1\end{array}$ & $\begin{array}{l}93.6 \\
65.4\end{array}$ & $\begin{array}{ccc}90.1 \\
90.1 \\
63.0\end{array}$ & $\begin{array}{c}80.1 \\
86.1 \\
60.3\end{array}$ & $\begin{array}{c}032.0 \\
82.0 \\
57.6\end{array}$ & $\begin{array}{l}0.27 .2 \\
75.8 \\
5.8\end{array}$ & $\begin{array}{ccc}77.3 \\
72.3 \\
51.9\end{array}$ & $\begin{array}{c}56.3 \\
67.3 \\
48.8\end{array}$ & $\begin{array}{c}50.5 \\
62.5 \\
46.1\end{array}$ & $\begin{array}{c}57.6 \\
53.4 \\
43.4\end{array}$ & $\begin{array}{c}52.8 \\
50.8 \\
40.8\end{array}$ & $\begin{array}{l}4.3 .3 \\
38.5 \\
4\end{array}$ & $\begin{array}{ll}44.1 \\
36.6\end{array}$ & $\begin{array}{c}4+1.3 \\
41.3 \\
35.1\end{array}$ & $\begin{array}{ccc}50.7 \\
34.5 \\
34.5\end{array}$ & $\begin{array}{c}50.3 \\
38.3 \\
34.1\end{array}$ & $\begin{array}{c}53.7 \\
33.6 \\
33.6\end{array}$ & $\begin{array}{c}35.0 \\
33.1 \\
33.1\end{array}$ & $\begin{array}{ll}33.5 \\
32.1\end{array}$ & 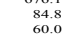 & $\begin{array}{l}24.7 \\
3.2 .2 \\
3.2\end{array}$ \\
\hline $\begin{array}{l}\text { Paris Club } \\
\text { Ohine ofial bilateral } \\
\text { Commercial }\end{array}$ & $\begin{aligned} 30.9 \\
00\end{aligned}$ & $\begin{array}{r}29.7 \\
00\end{array}$ & $\begin{array}{l}29.0 \\
00\end{array}$ & $\begin{array}{l}28.2 \\
0.2\end{array}$ & $\begin{array}{c}27.1 \\
00\end{array}$ & $\begin{array}{c}25.8 \\
0.8\end{array}$ & $\begin{array}{l}2.4 .6 \\
0.4 \\
0.4\end{array}$ & $\begin{array}{c}22.4 \\
0.0\end{array}$ & 20.4 & $\begin{array}{c}48.8 \\
18.4 \\
00\end{array}$ & $\begin{array}{c}46.1 \\
16.3 \\
00\end{array}$ & $\begin{array}{c}43.4 \\
14.2 \\
00\end{array}$ & 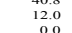 & $\begin{array}{c}38.5 \\
9.8 \\
0.0\end{array}$ & $\begin{array}{c}30.6 \\
7.5 \\
0.5\end{array}$ & $\begin{array}{c}35.1 \\
6.2 \\
0.0\end{array}$ & $\begin{array}{c}34.3 \\
5.2 \\
0.0\end{array}$ & $\begin{array}{r}34.1 \\
4.1 \\
00\end{array}$ & $\begin{array}{c}3.6 .0 \\
3.1 \\
0.0\end{array}$ & $\begin{array}{r}53.1 \\
2.0 \\
0.0\end{array}$ & $\begin{array}{c}3.1 .4 \\
1.4 \\
0.0\end{array}$ & $\begin{array}{c}24.8 \\
24.8 \\
0.0\end{array}$ & $\begin{array}{c}5.2 \\
6.6 \\
0.0\end{array}$ \\
\hline $\begin{array}{l}\text { Mutiniteral } \\
\text { Wort }\end{array}$ & $\begin{array}{c}673.5 \\
207.5 \\
209\end{array}$ & $\begin{aligned} 659.9 \\
2938\end{aligned}$ & $\begin{array}{l}636.7 \\
2054\end{array}$ & $\begin{aligned} 619.0 \\
2000\end{aligned}$ & $\begin{array}{l}612.0 \\
212.0 \\
2935\end{array}$ & 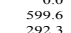 & $\begin{aligned} 581.2 \\
2853\end{aligned}$ & $\begin{array}{c}561.5 \\
278 \\
278\end{array}$ & 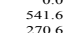 & $\begin{array}{c}50.0 \\
221.0 \\
222.9\end{array}$ & $\begin{array}{l}40.0 \\
228.1 \\
253.6\end{array}$ & $\begin{array}{l}40.0 \\
243.5 \\
22.7\end{array}$ & $\begin{array}{l}40.0 \\
238.7 \\
23.1\end{array}$ & $\begin{array}{l}0.0 . \\
43.6 \\
219.2\end{array}$ & 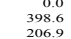 & $\begin{array}{c}30.0 \\
137.5 \\
142.2\end{array}$ & $\begin{array}{c}30.0 \\
137.9 \\
11.0\end{array}$ & $\begin{array}{c}32.0 \\
31.9 \\
167.4\end{array}$ & $\begin{array}{l}29.0 \\
15.4 \\
153.4\end{array}$ & $\begin{array}{c}20.0 \\
1.98 \\
138.8\end{array}$ & $\begin{array}{c}242.0 \\
124.4\end{array}$ & $\begin{array}{c}50.0 \\
281.3 \\
283.0\end{array}$ & $\begin{array}{c}35.0 .5 \\
185.9 \\
185\end{array}$ \\
\hline $\begin{array}{l}\text { World Bank } \\
\text { IAAB Group } \\
\text { IME }\end{array}$ & $\begin{array}{l}297.9 \\
342.8\end{array}$ & $\begin{array}{l}293.8 \\
333.3 \\
134\end{array}$ & 323.2 & $\begin{array}{r}312.3 \\
312\end{array}$ & $\begin{array}{l}301.1 \\
301\end{array}$ & $\begin{array}{l}289.6 \\
280 \\
0.03\end{array}$ & $\begin{array}{l}277.3 \\
27.9 \\
0.0\end{array}$ & $\begin{array}{l}278.1 \\
260.1 \\
0.030\end{array}$ & 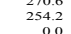 & $\begin{array}{r}241.8 \\
00\end{array}$ & $\begin{array}{r}228.8 \\
0.0\end{array}$ & $\begin{array}{r}215.8 \\
0.0\end{array}$ & $\begin{array}{l}203.2 \\
0.0\end{array}$ & $\begin{array}{l}219.2 \\
190.7 \\
0.0\end{array} \mathrm{~V} \mathrm{l}$ & $\begin{array}{l}178.7 \\
0.0\end{array}$ & $\begin{array}{l}167.0 \\
0.0\end{array}$ & $\begin{array}{l}118.0 \\
155.3 \\
0.0\end{array}-10$ & 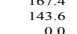 & $\begin{array}{c}133.4 \\
131.9 \\
0.0\end{array}-30$ & $\begin{array}{l}110.7 \\
120.7\end{array}$ & $\begin{array}{l}124.1 \\
109.7\end{array}$ & $\begin{aligned} & \begin{array}{r}283.0 \\
288.3 \\
28\end{array}-1 \\
&\end{aligned}$ & $\begin{array}{l}789.9 \\
161.6\end{array}$ \\
\hline $\begin{array}{l}\text { Other multilateral } \\
\text { NPV of new borrowing }\end{array}$ & $\begin{aligned} 17.7 \\
20.4 \\
0.0\end{aligned}$ & $\begin{array}{l}13.4 \\
\text { 19.3. } \\
45.4\end{array}$ & $\begin{aligned} 18.0 \\
126.1\end{aligned}$ & $\begin{array}{r}17.0 \\
198.7 \\
198.7\end{array}$ & $\begin{array}{r}17.0 \\
287.9\end{array}$ & $\begin{array}{r}1.0 \\
1.7 .7 \\
383.7\end{array}$ & $\begin{aligned} 0.0 \\
47.9 \\
477.7\end{aligned}$ & $\begin{aligned} 0.0 \\
17.4 \\
540.8\end{aligned}$ & $\begin{array}{r}0.0 \\
10.8 \\
620.4\end{array}$ & $\begin{aligned} 10.0 \\
724.0\end{aligned}$ & $\begin{aligned} 15.6 \\
828.2\end{aligned}$ & $\begin{aligned} 15.0 \\
15.0 \\
934.2\end{aligned}$ & $\begin{array}{r}0.0 \\
104.4 \\
1040.2\end{array}$ & $\begin{array}{r}0.0 \\
1163.8\end{array}$ & $\begin{array}{r}0.0 \\
13.1 \\
1295.6\end{array}$ & $\begin{aligned} 0.0 \\
12.4 \\
1430.0\end{aligned}$ & $\begin{array}{r}0.0 \\
1562.7\end{array}$ & $\begin{aligned} 0.0 \\
10.9 \\
1688.6\end{aligned}$ & $\begin{array}{r}0.0 \\
1804.1\end{array}$ & $\begin{aligned} 9.0 \\
1918.2\end{aligned}$ & $\begin{array}{r}0.0 \\
8.6 \\
2020.6\end{array}$ & $\begin{array}{r}17.8 \\
385.9\end{array}$ & $\begin{array}{c}11.9 \\
1,485.8\end{array}$ \\
\hline \multicolumn{24}{|l|}{ 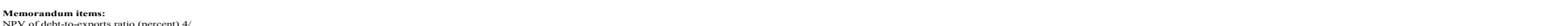 } \\
\hline $\begin{array}{l}\text { NPV of deb-t-o-exports } \\
\text { Total debt, } \\
\text { Total debs asuming } \mathrm{f}\end{array}$ & $\begin{array}{l}175.3 \\
150.0\end{array}-\mathrm{l} \mathrm{l}$ & $\begin{array}{l}158.9 \\
137.8\end{array}$ & $\begin{array}{l}153.5 \\
13.9 \\
13.9\end{array}$ & $\begin{array}{l}131.1 \\
131.1\end{array}$ & 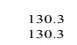 & 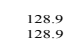 & $\begin{array}{l}126.9 \\
126.9\end{array} \mathrm{~V} \mathrm{C}$ & 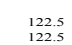 & $\begin{array}{l}120.1 \\
120.1\end{array}$ & $\begin{array}{l}119.5 \\
119.5\end{array}$ & $\begin{array}{l}118.7 \\
118.7\end{array}$ & $\begin{array}{l}117.4 \\
117.4\end{array}$ & $\begin{array}{l}115.6 \\
115.6\end{array}$ & $\begin{array}{l}114.7 \\
11.7\end{array}$ & $\begin{array}{l}113.9 \\
113.9\end{array}$ & $\begin{array}{l}112.9 \\
112.9\end{array}$ & $\begin{array}{l}111.4 \\
111.4\end{array}$ & 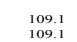 & $\begin{array}{l}105.9 \\
105.9\end{array}$ & 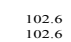 & $\begin{array}{c}98.6 \\
98.6\end{array}$ & $\begin{array}{l}135.1 \\
132.1\end{array}$ & $\begin{array}{l}110.2 \\
110.2\end{array}$ \\
\hline $\begin{array}{l}\text { Oustanding debt } \\
\text { NP of dob-tore ratio (percent }\end{array}$ & & & & & & & & & & & & & 37 & & & & & & & & & 94.4 & \\
\hline $\begin{array}{l}\text { Totat dect } \\
\text { Total debth asuming full delivery } \\
\text { Outstanding debt }\end{array}$ & $\begin{array}{l}\begin{array}{l}243.8 \\
208.6 \\
243.8\end{array} \\
240\end{array}$ & $\begin{array}{l}179.4 \\
155.5 \\
170.5\end{array}$ & $\begin{array}{l}188.0 \\
164.0 \\
163.9\end{array}$ & $\begin{array}{l}156.8 \\
156.8 \\
122.6\end{array}$ & $\begin{array}{l}152.9 \\
152.9 \\
108.5\end{array}$ & $\begin{array}{c}150.8 \\
150.8 \\
06.7\end{array}$ & $\begin{array}{l}14.3 \\
144.3 \\
38.9\end{array}$ & 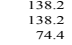 & 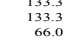 & $\begin{array}{l}730.1 \\
130.1 \\
58.3\end{array}$ & 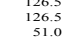 & $\begin{array}{l}12.6 \\
122.6 \\
44.5\end{array}$ & $\begin{aligned} & \begin{array}{r}118.6 \\
118.6 \\
38.6\end{array}-1 \\
& 38.6\end{aligned}$ & $\begin{array}{c}115.8 \\
115.8 \\
3.4 \\
3.4\end{array}$ & 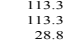 & $\begin{array}{l}110.7 \\
10.7 \\
24.9\end{array}$ & 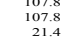 & $\begin{array}{c}104.3 \\
104.3 \\
18.3\end{array}$ & $\begin{array}{c}10.3 \\
100.3 \\
15.6\end{array}$ & $\begin{array}{l}96.2 \\
96.2 \\
13.2\end{array}$ & $\begin{array}{l}91.7 \\
91.7 \\
11.0\end{array}$ & $\begin{array}{l}158.5 \\
151.0 \\
112.7\end{array}$ & 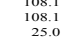 \\
\hline \multicolumn{24}{|c|}{ IV. After conditional delivery of enhanced HIPC and MDRI assistance $5 / 7 /$} \\
\hline $\begin{array}{l}\text { NPV of total debt } \\
\text { NPV of oustsanding debt }\end{array}$ & $\stackrel{920.7}{920.7}$ & $\begin{array}{l}921.0 \\
875.6\end{array}$ & 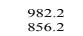 & 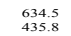 & $\begin{array}{l}709.8 \\
421.9\end{array}$ & $\begin{array}{l}790.8 \\
407.1 \\
40.1\end{array}$ & 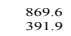 & 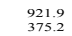 & 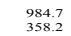 & $\begin{array}{c}1,064.7 \\
340.7\end{array}$ & 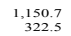 & 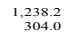 & 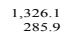 & $\begin{array}{l}1,431.9 \\
268.1\end{array}$ & $\begin{array}{l}1,546.8 \\
251.2\end{array}$ & 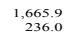 & 1, $1,784.4$ & 1.,896.7 208.1 & $\begin{array}{l}1,998.2 \\
194.0\end{array}-2$ & $\begin{array}{l}2,098.5 \\
108.4\end{array}$ & $\begin{array}{l}2,187.3 \\
166.7\end{array}$ & $\begin{array}{l}904.6 \\
518.7\end{array}$ & $\begin{array}{l}17.4 \\
13.6\end{array}$ \\
\hline $\begin{array}{l}\text { Official bilateral and comr } \\
\text { Paris club }\end{array}$ & $\begin{array}{l}182.2 \\
145.7 \\
14.7\end{array}$ & 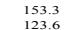 & $\begin{array}{l}157.2 \\
128.3\end{array}$ & $\begin{array}{l}93.6 \\
95.4 \\
65.4\end{array}$ & $\begin{array}{c}90.1 \\
60.0\end{array}$ & $\begin{array}{c}86.1 \\
60.3\end{array}$ & $\begin{array}{l}82.0 \\
5.6\end{array}-10$ & $\begin{array}{ll}772 \\
774 \\
548\end{array}$ & $\begin{array}{c}72.3 \\
5.1 .9 \\
5\end{array}$ & $\begin{array}{l}67.3 \\
48.8\end{array}$ & $\begin{array}{l}62.5 \\
46.1\end{array}$ & $\begin{array}{r}57.6 \\
43.4\end{array}$ & $\begin{array}{l}52.8 \\
40.8\end{array}$ & $\begin{array}{l}48.3 \\
38.5\end{array}$ & $\begin{array}{l}44.1 \\
36.6\end{array}$ & $\begin{array}{l}4.3 .3 \\
35.1\end{array}$ & $\begin{array}{l}39.7 \\
34.5\end{array}$ & $\begin{array}{l}38.3 \\
34.1\end{array}$ & $\begin{array}{r}36.7 \\
33.6\end{array}$ & $\begin{array}{r}35.0 \\
33.1\end{array}$ & $\begin{array}{l}33.5 \\
32.1\end{array}$ & $\begin{array}{l}102.2 \\
769\end{array}$ & $\begin{array}{l}42.7 \\
36.2\end{array}$ \\
\hline Oher official bilateral & 36.5 & 20.7 & 20.0 & $\begin{array}{l}0.4 \\
28.2 \\
-10\end{array}$ & 27.1 & 25.8 & 24.4 & 22.4 & 20.4 & $\begin{array}{l}78.8 \\
18.4\end{array}$ & 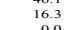 & $\begin{array}{l}3.4 .2 \\
14.2\end{array}$ & 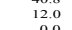 & 9.8 & 7.5 & 6.2 & 5.2 & 4.1 & 3.1. & $\begin{array}{r}3.1 .1 \\
2.0\end{array}$ & 1.4 & 25.3 & $\begin{array}{l}36.2 \\
6.6 \\
60\end{array}$ \\
\hline $\begin{array}{l}\text { Commercial } \\
\text { Multilateral }\end{array}$ & 738.5 & 722.3 & 698.9 & $\begin{array}{r}342.2 \\
342\end{array}$ & & $\begin{array}{r}32.0 \\
321.0\end{array}$ & $\begin{array}{r}0 \\
309 \\
-1\end{array}$ & & 285.9 & $\begin{array}{r}273.4 \\
2.4\end{array}$ & & 240 & $\begin{array}{r}233.0 \\
23.0\end{array}$ & $\begin{array}{r}219.8 \\
219.8\end{array}$ & 207.1 & $\begin{array}{r}0.0 \\
194.7\end{array}$ & $\begin{array}{l}0.0 \\
182.3 \\
-10\end{array}$ & $\begin{array}{c}169.8 \\
169.8 \\
-10\end{array}$ & 157.3 & $\begin{array}{l}14.0 .3 \\
.53\end{array}$ & & $\begin{array}{r}0.0 \\
416.5\end{array}$ & $\begin{array}{r}0.0 \\
188.9\end{array}$ \\
\hline $\begin{array}{l}\text { World Bank } \\
\text { IADB G Group }\end{array}$ & $\begin{array}{l}310.2 \\
384.0\end{array}$ & $\begin{array}{l}306.6 \\
376.5\end{array}$ & $\begin{array}{l}308.7 \\
368.3 \\
3\end{array}$ & $\begin{array}{c}12.8 \\
312.3\end{array}$ & $\begin{array}{r}13.2 \\
301.1\end{array}$ & $\begin{array}{r}13.7 \\
289.6\end{array}$ & $\begin{array}{r}14.1 \\
277.9\end{array}$ & $\begin{array}{l}1.5 \\
266.1\end{array}$ & $\begin{array}{l}14.9 \\
254.2\end{array}$ & $\begin{array}{c}15.4 \\
241.8\end{array}$ & $\begin{array}{c}15.6 \\
228.8\end{array}$ & $\begin{array}{c}15.5 \\
215.8\end{array}$ & $\begin{array}{l}15.5 \\
203.2\end{array}$ & $\begin{array}{l}15.4 \\
190.7 \\
\mathrm{C} \mathrm{Cl}\end{array}$ & $\begin{array}{c}155.4 \\
178.7 \\
-10\end{array}$ & $\begin{array}{l}15.4 \\
167.0\end{array}$ & $\begin{array}{c}15.3 \\
155.3 \\
-1\end{array}$ & $\begin{array}{l}145.3 \\
143.6 \\
-10\end{array}$ & 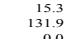 & $\begin{array}{c}15.2 \\
120.7\end{array}$ & $\begin{array}{c}14.9 \\
109.7\end{array}$ & $\begin{array}{l}94.5 \\
300.1\end{array}$ & $\begin{array}{c}15.3 \\
161.6 \\
160\end{array}$ \\
\hline 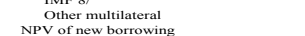 & $\begin{array}{c}23.8 \\
23.8 \\
0.0\end{array}$ & $\begin{array}{l}12.8 \\
22.8 \\
45.4\end{array}$ & $\begin{array}{r}21.9 \\
126.1\end{array}$ & $\begin{aligned} 17.0 \\
198.7\end{aligned}$ & $\begin{aligned} 17.04 \\
287.9\end{aligned}$ & $\begin{array}{r}11.7 \\
383.7\end{array}$ & $\begin{array}{r}179 \\
477.7\end{array}$ & $\begin{array}{c}17.0 \\
54.4 \\
54.8\end{array}$ & $\begin{aligned} 10.8 \\
62.8 \\
62.4\end{aligned}$ & $\begin{aligned} 16.0 \\
774.0\end{aligned}$ & $\begin{array}{r}15.6 \\
828.6 \\
828.2\end{array}$ & $\begin{aligned} 15.0 \\
934.2\end{aligned}$ & $\begin{aligned} 1.0 .4 \\
1040.2\end{aligned}$ & $\begin{array}{r}13.7 \\
1163.8\end{array}$ & $\begin{array}{r}13.1 \\
129.1 \\
129.6\end{array}$ & $\begin{aligned} 12.4 \\
1430.0\end{aligned}$ & $\begin{aligned} 11.7 \\
152.4\end{aligned}$ & $\begin{aligned} 10.9 \\
109 \\
168.6\end{aligned}$ & $\begin{array}{r}10.2 \\
180.2\end{array}$ & $\begin{aligned} 0.4 \\
9.4 \\
191.22\end{aligned}$ & $\begin{array}{r}8.6 \\
20.6 \\
202.6\end{array}$ & $\begin{array}{r}18.6 \\
385.9\end{array}$ & $\begin{array}{c}11.9 \\
1.9 \\
1.845 .8\end{array}$ \\
\hline \multicolumn{24}{|c|}{ tanced HIPC and MDRI assistan } \\
\hline NPV of total debt & 920.7 & $\begin{array}{l}921.0 \\
9856\end{array}$ & 982.2 & $\begin{array}{l}569.3 \\
3776\end{array}$ & $\begin{array}{l}647.0 \\
6.530\end{array}$ & $\begin{array}{l}730.7 \\
3470\end{array}$ & 812.2 & 867.3 & 933.0 & $\begin{array}{l}1,016.0 \\
200\end{array}$ & $\begin{array}{l}1,104.7 \\
27.6\end{array}$ & $\begin{array}{l}1,194.9 \\
1,267\end{array}$ & $1,285.4$ & $\begin{array}{r}1,393.4 \\
229.7\end{array}$ & $\begin{array}{l}1,510.2 \\
214.6\end{array}$ & $\begin{array}{l}1,630.9 \\
2010\end{array}$ & $\begin{array}{l}1,749.9 \\
18.5\end{array}$ & $\begin{array}{l}1,862.5 \\
177.0\end{array}$ & $\begin{array}{l}1,964.5 \\
10.4\end{array}$ & $\begin{array}{l}2,065.5 \\
14.73\end{array}$ & $\begin{array}{l}2,155.2 \\
134.6\end{array}$ & $\begin{array}{l}864.0 \\
478.1\end{array}$ & \\
\hline 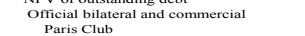 & $\begin{array}{l}182.2 \\
182.2 \\
14.7\end{array}$ & $\begin{array}{l}153.3 \\
123.6 \\
123.6\end{array}$ & $\begin{array}{l}8157.2 \\
157.2 \\
12.3\end{array}$ & $\begin{array}{l}28.5 \\
0.2\end{array}$ & $\begin{array}{l}37.4 \\
27.4 \\
0.2\end{array}$ & $\begin{array}{l}346.0 \\
0.2 \\
0.2\end{array}$ & 0.2 & $\begin{array}{l}32.6 \\
2.2 .6 \\
0.2\end{array}$ & $\begin{array}{l}30.6 \\
20.6 \\
0.2\end{array}$ & $\begin{array}{l}218.6 \\
18.2 \\
0.2\end{array}$ & $\begin{array}{r}16.5 \\
0.1\end{array}$ & $\begin{array}{c}14.3 \\
0.1\end{array}$ & $\begin{array}{c}212.1 \\
0.1\end{array}$ & $\begin{aligned} 9.8 \\
0.0\end{aligned}$ & $\begin{array}{r}7.5 \\
0.0 \\
\end{array}$ & $\begin{array}{r}6.2 \\
6.0\end{array}$ & $\begin{array}{l}5.2 \\
0.0\end{array}$ & $\begin{array}{l}4.1 \\
0.0\end{array}$ & $\begin{array}{r}3.1 \\
0.0 \\
0.0\end{array}$ & $\begin{array}{r}2.0 \\
0.0\end{array}$ & $\begin{array}{l}1.4 \\
0.4 \\
0.0\end{array}$ & $\begin{aligned} 61.6 \\
61.6 \\
36.3\end{aligned}$ & $\begin{array}{ll}6.6 \\
0.0\end{array}$ \\
\hline $\begin{array}{l}\text { Other official bilateral } \\
\text { Commercial }\end{array}$ & 365 & $\begin{array}{l}29.7 \\
0.0\end{array}$ & $\begin{array}{c}29.0 \\
0.0\end{array}$ & $\begin{array}{c}28.2 \\
00\end{array}$ & $\begin{array}{c}27.1 \\
0.0\end{array}$ & $\begin{array}{c}25.8 \\
0.0\end{array}$ & 24. & $\begin{array}{c}22.4 \\
0.0\end{array}$ & $\begin{array}{c}20.4 \\
0.0\end{array}$ & $\begin{array}{c}18.4 \\
0.0\end{array}$ & $\begin{array}{c}16 \\
0\end{array}$ & 1 & $\begin{array}{c}12.0 \\
00\end{array}$ & & $\begin{array}{l}7.5 \\
0.0\end{array}$ & & $\begin{array}{l}5.2 \\
0.2\end{array}$ & $\begin{array}{l}4.1 \\
0.0\end{array}$ & 10 & & & $\begin{array}{c}25.3 \\
00\end{array}$ & $\begin{array}{l}6.6 \\
0.6\end{array}$ \\
\hline $\begin{array}{l}\text { Multilateral } \\
\text { NPV of rew borrowing }\end{array}$ & $\begin{array}{r}738.5 \\
0.0\end{array}$ & $\begin{array}{r}722.3 \\
45.4\end{array}$ & $\begin{array}{l}698.9 \\
126.1\end{array}$ & $\begin{array}{l}342.2 \\
198.7\end{array}$ & $\begin{array}{l}331.7 \\
2879\end{array}$ & $\begin{array}{l}321.0 \\
383.7 \\
38.7 \\
\end{array}$ & $\begin{array}{l}309.9 \\
47.7\end{array}$ & 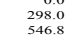 & $\begin{array}{l}285.9 \\
62.9 \\
62.4\end{array} \mathrm{l} \mathrm{l}$ & 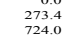 & $\begin{array}{l}260.0 \\
888.2\end{array}$ & $\begin{array}{l}246.4 \\
934.2\end{array}$ & $\begin{array}{r}233.0 \\
1.040 .2\end{array}$ & $\begin{array}{r}219.8 \\
1.163 .8 \\
\end{array}$ & $\begin{aligned} 207.1 \\
1.29 .1 \\
1.56\end{aligned}$ & $\begin{aligned} 194.7 \\
1.430 .0\end{aligned}$ & $\begin{aligned} 18.3 \\
1.562 .3 \\
1.56\end{aligned}$ & $\begin{aligned} 169.8 \\
1698.6\end{aligned}$ & $\begin{array}{r}157.3 \\
1.80 .4 \\
1.1\end{array}$ & $\begin{aligned} 145.3 \\
1.913 .2\end{aligned}$ & $\begin{array}{r}13.2 .2 \\
2.020 .6\end{array}$ & $\begin{array}{l}416.5 \\
385.9\end{array}$ & $\begin{array}{l}188.9 \\
1.985 \\
-1485.8\end{array}$ \\
\hline \multicolumn{24}{|l|}{ 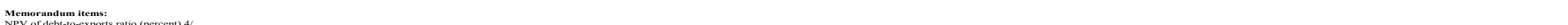 } \\
\hline 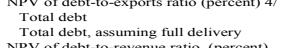 & $\begin{array}{l}175.3 \\
150.0\end{array}$ & $\begin{array}{l}158.9 \\
137.8\end{array}$ & $\begin{array}{l}153.5 \\
133.9\end{array}$ & 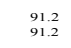 & 93.4. & 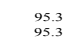 & $\begin{array}{l}96.8 \\
96.8\end{array}$ & $\begin{array}{l}95.3 \\
95.3\end{array}$ & $\begin{array}{l}95.4 \\
95.4\end{array}$ & $\begin{array}{l}96.9 \\
96.9\end{array}$ & $\begin{array}{l}98.4 \\
98.4\end{array}$ & $\begin{array}{l}99.2 \\
99.2\end{array}$ & 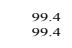 & 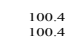 & $\begin{array}{l}101.4 \\
101.4\end{array}$ & $\begin{array}{l}102.0 \\
102.0\end{array}$ & $\begin{array}{l}101.9 \\
101.9\end{array}$ & $\begin{array}{l}1010.0 \\
101.0\end{array}$ & $\begin{array}{l}99.1 \\
99.1\end{array}$ & $\begin{array}{l}96.9 \\
96.9\end{array}$ & $\begin{array}{l}93.9 \\
93.9\end{array}$ & $\begin{array}{l}113.7 \\
107.7\end{array}$ & 99.5 \\
\hline 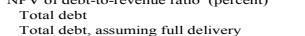 & $\begin{array}{l}243.8 \\
208.6\end{array}$ & $\begin{array}{l}179.4 \\
155.5\end{array}$ & $\begin{array}{l}188.0 \\
164.0\end{array}$ & $\begin{array}{l}109.1 \\
109.1\end{array}$ & $\begin{array}{l}109.6 \\
109.6\end{array}$ & $\begin{array}{l}111.5 \\
111.5\end{array}$ & $\begin{array}{l}110.0 \\
110.0\end{array}$ & $\begin{array}{l}107.4 \\
107.4\end{array}$ & 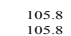 & $\begin{array}{l}105.5 \\
105.5\end{array}$ & $\begin{array}{l}104.8 \\
104.8\end{array}$ & $\begin{array}{l}103.6 \\
103.6\end{array}$ & $\begin{array}{l}102.1 \\
102.1\end{array}$ & $\begin{array}{l}101.4 \\
101.4\end{array}$ & $\begin{array}{l}100.8 \\
10.8\end{array}$ & $\begin{array}{c}99.9 \\
99.9\end{array}$ & $\begin{array}{c}98.6 \\
98.6\end{array}$ & $\begin{array}{c}96.6 \\
96.6\end{array}$ & $\begin{array}{l}93.8 \\
93.8 \\
-10\end{array}$ & $\begin{array}{l}90.8 \\
90.8\end{array}$ & $\begin{array}{l}87.3 \\
87.3\end{array}$ & $\begin{array}{l}134.1 \\
126.5\end{array}$ & 97.5 \\
\hline
\end{tabular}

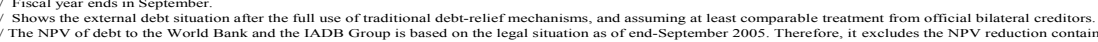

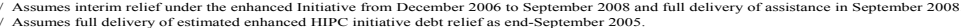

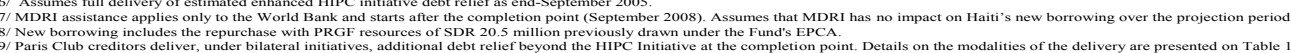

CInternational Monetary Fund. Not for Redistribution 
Table A6. Haiti: External Debt Indicators, 2005-25 1/

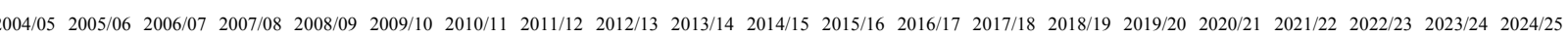

\begin{tabular}{|c|c|c|c|c|c|c|c|c|c|c|c|c|c|c|c|c|c|c|c|c|c|c|c|}
\hline \multirow{2}{*}{\multicolumn{24}{|c|}{ (In percent, unless otherwise indicated) }} \\
\hline & & & & & & & & & & & & & & & & & & & & & & & \\
\hline $\begin{array}{l}\text { NPV of debt-to-GDP ratio } \\
\text { NPV of debt-to-exports ratio } 2 / 3 /\end{array}$ & $\begin{array}{l}23.9 \\
177.6\end{array}$ & $\begin{array}{c}16.1 \\
165.6\end{array}$ & $\begin{array}{l}157.1 \\
157.0\end{array}$ & $\begin{array}{l}15.0 \\
151.9\end{array}$ & $\begin{array}{l}1.90 \\
147.7\end{array}$ & $\begin{array}{l}18.9 \\
143.8\end{array}$ & 140.3 & $\begin{array}{l}13.3 \\
134.7\end{array}$ & $\begin{array}{c}17.9 \\
131.2\end{array}$ & $\begin{array}{r}17.7 \\
129.6\end{array}$ & $\begin{array}{l}17.5 \\
127.9\end{array}$ & $\begin{array}{c}17.2 \\
125.7\end{array}$ & $\begin{array}{c}16.9 \\
123.0\end{array}$ & $\begin{array}{c}16.7 \\
121.3\end{array}$ & $\begin{array}{r}16.6 \\
119.8\end{array}$ & $\begin{array}{r}16.5 \\
118.2\end{array}$ & $\begin{array}{r}16.3 \\
116.0\end{array}$ & $\begin{array}{r}16.0 \\
113.2\end{array}$ & $\begin{array}{r}15.6 \\
1095\end{array}$ & 15.2 & $\begin{array}{r}14.7 \\
1012\end{array}$ & $\begin{array}{r}19.2 \\
1179\end{array}$ & $\begin{array}{r}16.3 \\
116.5\end{array}$ \\
\hline NPV of debt-to-revenue ratio $4 /$ & 247.0 & 186.9 & 192.3 & 181.6 & 173.4 & 168.2 & 159.5 & 151.9 & 145.6 & 141.1 & 136.2 & 131.3 & 126.2 & 122.4 & 119.1 & 115.8 & 112.3 & 108.3 & 103.7 & 99.1 & 94.1 & 174.8 & 115.3 \\
\hline Debt service ratio & $\ldots . .$. & 9.6 & 13.4 & 8.4 & 8.0 & 7.7 & 7.3 & 7.0 & 7.6 & 7.7 & 7.9 & 7.8 & 7.6 & 6.6 & 6.1 & 5.7 & 5.4 & 5.4 & 5.2 & 5.1 & 4.9 & 8.5 & $6.2>>2>3$ \\
\hline Debt service-to-revenue ratio 4 / & $\ldots$ & 11.8 & 17.7 & 11.0 & 10.2 & 9.7 & 8.9 & 8.4 & 9.0 & 9.0 & 9.0 & 8.7 & 8.3 & 7.1 & 6.5 & 5.9 & 5.6 & 5.5 & 5.3 & 5.1 & 4.9 & 10.6 & 6.5 \\
\hline \multicolumn{24}{|l|}{ After traditional debt relief } \\
\hline NPV of debt-to-GDP ratio & 22.7 & 18.2 & 18.3 & 18.2 & 18.3 & 18.3 & 18.2 & 17.8 & 17.5 & 17.4 & 17.2 & 17.0 & 16.7 & 16.6 & 16.5 & 16.4 & 16.2 & 15.9 & 15.5 & 15.1 & 14.6 & 18.5 & 16.2 \\
\hline NPV of debt-to-exports ratio $2 / 3 /$ & 168.6 & 157.8 & 150.3 & 146.0 & 142.6 & 139.4 & 136.5 & 131.4 & 128.4 & 127.2 & 125.9 & 124.0 & 121.7 & 120.2 & 119.0 & 117.5 & 115.5 & 112.7 & 109.1 & 105.3 & 100.9 & 0.0 & 115.6 \\
\hline NPV of debt-to-revenue ratio $4 /$ & 234.5 & 178.1 & 184.1 & 174.7 & 167.4 & 163.1 & 155.2 & 148.2 & 142.5 & 138.5 & 134.1 & 129.6 & 124.9 & 121.4 & 118.3 & 115.2 & 111.8 & 107.8 & 103.3 & 98.7 & 93.8 & 168.6 & 114.4 \\
\hline Debt service ratio & $\ldots$ & 9.1 & 13.0 & 8.0 & 7.7 & 7.4 & 7.0 & 6.7 & 7.4 & 7.5 & 7.7 & 7.6 & 7.4 & 6.5 & 6.0 & 5.6 & 5.4 & 5.4 & 5.3 & 5.1 & 5.0 & 8.2 & 6.1 \\
\hline Debt service-to-revenue ratio 4 / & $\ldots$ & 11.2 & 17.1 & 10.5 & 9.8 & 9.4 & 8.6 & 8.1 & 8.7 & 8.7 & 8.7 & 8.5 & 8.1 & 7.0 & 6.4 & 5.9 & 5.6 & 5.5 & 5.3 & 5.1 & 5.0 & 10.2 & 6.5 \\
\hline \multicolumn{24}{|l|}{ After conditional delivery of enhanced HIPC assistance } \\
\hline NPV of debt-to-GDP ratio & 23.6 & 18.4 & 18.7 & 16.4 & 16.7 & 17.0 & 17.0 & 16.6 & 16.4 & 16.4 & 16.3 & 16.1 & 15.9 & 15.8 & 15.8 & 15.7 & 15.6 & 15.4 & 15.1 & 14.7 & 14.3 & 17.7 & 15.5 \\
\hline NPV of debt-to-exports ratio $2 / 3 /$ & 175.3 & 158.9 & 153.5 & 131.1 & 130.3 & 128.9 & 126.9 & 122.5 & 120.1 & 119.5 & 118.7 & 117.4 & 115.6 & 114.7 & 113.9 & 112.9 & 111.4 & 109.1 & 105.9 & 102.6 & 98.6 & 136.7 & 111.0 \\
\hline NPV of debt-to-exports ratio (existing debt only) & 175.3 & 151.1 & 133.8 & 102.5 & 92.4 & 82.6 & 73.8 & 66.0 & 59.5 & 53.6 & 47.9 & 42.6 & 37.6 & 33.1 & 29.0 & 25.4 & 22.1 & 19.2 & 16.5 & 14.0 & 11.8 & 99.1 & 27.2 \\
\hline NPV of debt-to-revenue ratio $4 /$ & 243.8 & 179.4 & 188.0 & 156.8 & 152.9 & 150.8 & 144.3 & 138.2 & 133.3 & 130.1 & 126.5 & 122.6 & 118.6 & 115.8 & 113.3 & 110.7 & 107.8 & 104.3 & 100.3 & 96.2 & 91.7 & 161.7 & 109.8 \\
\hline Debt service-to-exports ratio & $\ldots$ & 9.3 & 11.0 & 7.1 & 5.9 & 6.2 & 6.5 & 6.2 & 6.9 & 7.1 & 7.2 & 7.2 & 6.9 & 6.1 & 5.7 & 5.3 & 5.1 & 5.0 & 4.9 & 4.8 & 4.7 & 7.4 & 5.7 \\
\hline Debt service-to-revenue ratio 4 / & $\ldots$ & 11.4 & 14.6 & 9.4 & 7.5 & 7.8 & 7.9 & 7.5 & 8.2 & 8.2 & 8.2 & 8.0 & 7.6 & 6.5 & 6.0 & 5.5 & 5.2 & 5.1 & 5.0 & 4.8 & 4.6 & 9.2 & 6.1 \\
\hline \multicolumn{24}{|c|}{ After unconditional delivery of enhanced HIPC assistance } \\
\hline NPV of debt-to-GDP ratio & 20.2 & 15.9 & 16.3 & 16.4 & 16.7 & 17.0 & 17.0 & 16.6 & 16.4 & 16.4 & 16.3 & 16.1 & 15.9 & 15.8 & 15.8 & 15.7 & 15.6 & 15.4 & 15.1 & 14.7 & 14.3 & 16.9 & 15.5 \\
\hline & 150.0 & 137 & 133.9 & 131 & 130.3 & 128.9 & 126.9 & 122.5 & 120.1 & 119.5 & 118.7 & 117 & 115.6 & 11 & 113 & 112.9 & 111.4 & 109.1 & 105.9 & 102 & & 130.1 & 111.0 \\
\hline NPV & 150.0 & 129.9 & 114.2 & 102.5 & 92.4 & 82 & 73.8 & 66. & 59 & 53.6 & 47.9 & & 37 & 33.1 & 29 & 25.4 & 22.1 & 19.2 & & & & 92.5 & 27.2 \\
\hline NPV of debt-to-revenue ratio 4 / & 208.6 & 155.5 & 164.0 & 156.8 & 152.9 & 150.8 & 144.3 & 138.2 & 133.3 & 130.1 & 126.5 & 122.6 & 118.6 & 115.8 & 113.3 & 110.7 & 107.8 & 104.3 & 100.3 & 96.2 & 91.7 & 153.4 & 109.8 \\
\hline Debt service-to-exports ratio & $\ldots$ & 9.3 & 11.0 & 7.1 & 5.9 & 6.2 & 6.5 & 6.2 & 6.9 & 7.1 & 7.2 & 7.2 & 6.9 & 6.1 & 5.7 & 5.3 & 5.1 & 5.0 & 4.9 & 4.8 & 4.7 & 7.4 & 5.7 \\
\hline Debt service-to-revenue ratio 4 / & $\ldots$ & 11.4 & 14.6 & 9.4 & 7.5 & 7.8 & 7.9 & 7.5 & 8.2 & 8.2 & 8.2 & 8.0 & 7.6 & 6.5 & 6.0 & 5.5 & 5.2 & 5.1 & 5.0 & 4.8 & 4.6 & 9.2 & 6.1 \\
\hline \multicolumn{24}{|c|}{ After conditional delivery of enhanced HIPC and MDRI assistance 5/ } \\
\hline NPV of debt-to-GDP ratio & 23.6 & 18.4 & 18.7 & 11.4 & 12.0 & 12.5 & 12.9 & 12.9 & 13.0 & 13.3 & 13.5 & 13.6 & 13.7 & 13.9 & 14.1 & 14.2 & 14.3 & 14.3 & 14.1 & 13.9 & 13.6 & 14.9 & 13.9 \\
\hline NPV of debt-to-exports ratio $2 / 3 /$ & 175.3 & 158.9 & 153.5 & 91.2 & 93.4 & 95.3 & 96.8 & 95.3 & 95.4 & 96.9 & 98.4 & 99.2 & 99.4 & 100.4 & 101.4 & 102.0 & 101.9 & 101.0 & 99.1 & 96.9 & 93.9 & 115.2 & 99.4 \\
\hline NPV of debt-to-exports ratio (existing debt only) & 175.3 & 151.1 & 133.8 & 62.7 & 55.5 & 49.1 & 43.6 & 38.8 & 34.7 & 31.0 & 27.6 & 24.4 & 21.4 & 18.8 & 16.5 & 14.4 & 12.7 & 11.1 & 9.6 & 8.3 & 7.2 & 77.5 & 15.6 \\
\hline NPV of debt-to-revenue ratio $4 /$ & 243.8 & 179.4 & 188.0 & 109.1 & 109.6 & 111.5 & 110.0 & 107.4 & 105.8 & 105.5 & 104.8 & 103.6 & 102.1 & 101.4 & 100.8 & 99.9 & 98.6 & 96.6 & 93.8 & 90.8 & 87.3 & 137.0 & 98.2 \\
\hline Debt service-to-exports ratio & $\ldots$ & 9.3 & 11.0 & 7.1 & 4.8 & 4.6 & 4.4 & 4.3 & 5.1 & 5.4 & 5.6 & 5.6 & 5.4 & 4.7 & 4.4 & 4.1 & 3.9 & 4.0 & 3.9 & 3.9 & 3.9 & 6.2 & 4.5 \\
\hline Debt service-to-revenue ratio $4 /$ & & 11.4 & 14.6 & 9.4 & 6.1 & 5.8 & 5.4 & 5.2 & 6.1 & 6.2 & 6.4 & 6.2 & 5.9 & 5.0 & 4.7 & 4.3 & 4.1 & 4.1 & 4.0 & 3.9 & 3.9 & 7.8 & 4.8 \\
\hline
\end{tabular}

Sources: Haitian authorities and staff estimates and projections.

作

a defined as in IMF, Balance of Payments Manual, 5th edition, 1993.

4 / Revenue is defined as central government revenue, excluding grants.

5/MDRI assistance applies only to the World Bank and starts after the completion point (September 2008). Assumes that MDRI has no impact on Haiti's new borrowing over the projection period. 
Table A7. Haiti: External Debt Indicators and Sensitivity Analysis, 2005-25 1/

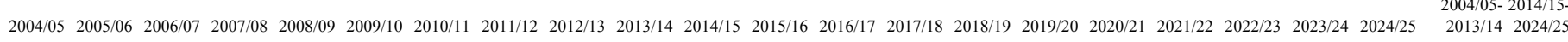

\begin{tabular}{|c|c|c|c|c|c|c|c|c|c|c|c|c|c|c|c|c|c|c|c|c|c|c|c|}
\hline \multirow{2}{*}{ Baseline scenario } & \multicolumn{23}{|c|}{ (In percent, unless otherwise indicated) } \\
\hline & & & & & & & & & & & & & & & & & & & & & & & \\
\hline NPV of debt-to-GDP ratio & 20.2 & 15.9 & 16.3 & 16.4 & 16.7 & 17.0 & 17.0 & 16.6 & 16.4 & 16.4 & 16.3 & 16.1 & 15.9 & 15.8 & 15.8 & 15.7 & 15.6 & 15.4 & 15.1 & 14.7 & 14.3 & 16.9 & 15.5 \\
\hline NPV of debt-to-exports ratio $2 / 3 /$ & 150.0 & 137.8 & 133.9 & 131.1 & 130.3 & 128.9 & 126.9 & 122.5 & 120.1 & 119.5 & 118.7 & 117.4 & 115.6 & 114.7 & 113.9 & 112.9 & 111.4 & 109.1 & 105.9 & 102.6 & 98.6 & 130.1 & 111.0 \\
\hline NPV of debt-to-revenue ratio 4/ & 208.6 & 155.5 & 164.0 & 156.8 & 152.9 & 150.8 & 144.3 & 138.2 & 133.3 & 130.1 & 126.5 & 122.6 & 118.6 & 115.8 & 113.3 & 110.7 & 107.8 & 104.3 & 100.3 & 96.2 & 91.7 & 153.4 & 109.8 \\
\hline Debt service-to-exports ratio & $\ldots$ & 9.3 & 11.0 & 7.1 & 5.9 & 6.2 & 6.5 & 6.2 & 6.9 & 7.1 & 7.2 & 7.2 & 6.9 & 6.1 & 5.7 & 5.3 & 5.1 & 5.0 & 4.9 & 4.8 & 4.7 & 7.4 & 5.7 \\
\hline Debt service-to-revenue ratio & $\ldots$ & 11.4 & 14.6 & 9.4 & 7.5 & 7.8 & 7.9 & 7.5 & 8.2 & 8.2 & 8.2 & 8.0 & 7.6 & 6.5 & 6.0 & 5.5 & 5.2 & 5.1 & 5.0 & 4.8 & 4.6 & 9.2 & 6.1 \\
\hline \multirow{2}{*}{\multicolumn{24}{|c|}{ Sensitivity analysis }} \\
\hline \multicolumn{2}{|c|}{ Less concessional new borrowing scenario $5 /$} & & & & & & & & & & & & & & & & & & & & & & \\
\hline NPV of debt-to-exports ratio $2 / 3 /$ & 150.0 & 139.5 & 137.8 & 137.5 & 138.8 & 139.4 & 139.1 & 135.2 & 133.8 & 134.5 & 135.1 & 134.8 & 133.7 & 133.5 & 133.2 & 132.4 & 130.8 & 128.3 & 124.6 & 120.6 & 115.7 & 138.6 & 129.3 \\
\hline NPV of debt-to-revenue ratio 4/ & 208.6 & 157.5 & 168.7 & 164.5 & 163.0 & 163.1 & 158.2 & 152.5 & 148.4 & 146.5 & 143.9 & 140.8 & 137.2 & 134.7 & 132.4 & 129.8 & 126.6 & 122.7 & 117.9 & 113.1 & 107.7 & 163.1 & 127.9 \\
\hline Debt service-to-exports ratio & $\ldots$ & 9.4 & 11.4 & 7.6 & 6.6 & 7.0 & 7.4 & 7.3 & 8.1 & 8.3 & 8.5 & 8.5 & 8.4 & 7.5 & 7.2 & 6.8 & 6.6 & 6.5 & 6.4 & 6.2 & 6.1 & 8.1 & 7.2 \\
\hline Debt service-to-revenue ratio 4 / & $\ldots$ & 11.6 & 15.0 & 10.0 & 8.4 & 8.9 & 9.1 & 8.8 & 9.5 & 9.6 & 9.7 & 9.5 & 9.2 & 8.1 & 7.6 & 7.1 & 6.8 & 6.7 & 6.5 & 6.3 & 6.1 & 10.1 & 7.6 \\
\hline \multicolumn{24}{|l|}{ Lower export growth 6 / } \\
\hline NPV of debt-to-exports ratio $2 / 3 /$ & 150.0 & 138.1 & 136.7 & 138.8 & 144.0 & 148.6 & 151.6 & 150.8 & 151.0 & 152.9 & 155.0 & 156.7 & 158.1 & 160.8 & 163.9 & 167.0 & 169.5 & 171.2 & 171.8 & 172.2 & 171.7 & 146.3 & 165.3 \\
\hline NPV of debt-to-revenue ratio 4/ & 208.6 & 155.6 & 165.3 & 159.5 & 156.6 & 155.7 & 150.2 & 144.7 & 140.5 & 138.1 & 135.3 & 132.3 & 129.2 & 127.3 & 125.7 & 124.1 & 122.2 & 119.8 & 116.7 & 113.6 & 110.1 & 157.5 & 123.3 \\
\hline Debt service-to-exports ratio & $\ldots$ & 9.3 & 11.6 & 7.9 & 6.7 & 7.3 & 7.9 & 7.8 & 8.8 & 9.1 & 9.5 & 9.5 & 9.4 & 8.4 & 8.1 & 7.7 & 7.6 & 7.7 & 7.8 & 7.8 & 7.9 & 8.5 & 8.3 \\
\hline Debt service-to-revenue ratio 4 / & $\ldots$ & 11.4 & 14.7 & 9.5 & 7.7 & 8.0 & 8.2 & 7.8 & 8.6 & 8.6 & 8.7 & 8.4 & 8.1 & 7.0 & 6.5 & 6.0 & 5.7 & 5.7 & 5.5 & 5.4 & 5.3 & 9.4 & 6.6 \\
\hline \multicolumn{24}{|l|}{ Lower G } \\
\hline $\mathrm{NPV}$ of debt-to-exports ratio $2 / 3 /$ & 150.0 & 138.1 & 134.9 & 133.2 & 133.7 & 133.9 & 133.9 & 131.8 & 132.0 & 134.4 & 136.9 & 139.2 & 141.3 & 144.5 & 148.0 & 151.5 & 154.6 & 157.2 & 159.0 & 160.7 & 161.8 & 135.6 & 150.4 \\
\hline NPV of debt-to-revenue ratio 4 / & 208.6 & 158.8 & 171.4 & 168.3 & 169.0 & 171.9 & 170.3 & 169.5 & 170.3 & 173.3 & 176.1 & 178.9 & 181.8 & 186.3 & 191.6 & 197.1 & 202.4 & 207.2 & 211.4 & 215.7 & 219.6 & 173.1 & 197.1 \\
\hline Debt service-to-exports ratio & $\ldots$ & 9.3 & 11.1 & 7.2 & 6.0 & 6.3 & 6.6 & 6.5 & 7.2 & 7.4 & 7.7 & 7.7 & 7.5 & 6.7 & 6.4 & 6.1 & 6.0 & 6.1 & 6.1 & 6.2 & 6.2 & 7.5 & 6.6 \\
\hline Debt service-to-revenue ratio 4/ & $\ldots$ & 11.6 & 15.2 & 10.0 & 8.2 & 8.7 & 9.1 & 8.9 & 9.9 & 10.2 & 10.5 & 10.5 & 10.3 & 9.2 & 8.9 & 8.5 & 8.5 & 8.7 & 8.8 & 8.9 & 9.0 & 10.2 & 9.3 \\
\hline
\end{tabular}

Sources: Haitian authorities and staff estimates and projections.

1/ All debt indicators refer to public and publicly guaranteed (PPG) debt and are defined after HIPC assistance assumed delivered unconditionally at end-September 2005. Fiscal year ends in September

2/ As defined in IMF, Balance of Payments Manual, 5th edition, 1993.

3/ Based on a three-year average of exports on the previous year (e.g., export average over 1999-2001 for NPV of debt-to-exports ratio in 2001).

4/ Revenue is defined as central government revenue, excluding grants.

$5 /$ Assumes that the interest rate on all debt is 1 percentage point higher than in the baseline from 2006 onwards, implying a 12 percentage point reduction in grant element.

6/ Assumes on average 3 percentage points lower export growth 2006-26. 
Table A8. HIPC Initiative: Status of Country Cases Considered Under the Initiative, September 26, 2006

\begin{tabular}{|c|c|c|c|c|c|c|c|c|c|c|c|}
\hline \multirow[b]{3}{*}{ Country } & \multirow{3}{*}{$\begin{array}{r}\text { Decision } \\
\text { Point }\end{array}$} & \multirow{3}{*}{$\begin{array}{r}\text { Completion } \\
\text { Point }\end{array}$} & \multicolumn{2}{|c|}{$\begin{array}{c}\text { Target } \\
\text { NPV of Debt-to- } \\
\end{array}$} & \multirow{2}{*}{\multicolumn{5}{|c|}{$\begin{array}{c}\text { Assistance Levels 1/ } \\
\text { (In millions of U.S. dollars, present value) }\end{array}$}} & \multirow{3}{*}{$\begin{array}{r}\text { Percentage } \\
\text { Reduction } \\
\text { in NPV of } \\
\text { Debt } 2 / \\
\end{array}$} & \multirow{3}{*}{$\begin{array}{l}\text { Estimated Total } \\
\text { Nominal Debt } \\
\text { Service Relief } \\
\text { (In millions of } \\
\text { U.S. dollars) }\end{array}$} \\
\hline & & & & Gov. & & & & & & & \\
\hline & & & \multicolumn{2}{|c|}{ (in percent) } & Total & $\begin{array}{l}\text { Bilateral and } \\
1 \text { commercial } \\
\end{array}$ & $\begin{array}{l}\text { Multi- } \\
\text { lateral }\end{array}$ & IMF & $\begin{array}{r}\text { World } \\
\text { Bank }\end{array}$ & & \\
\hline \multicolumn{12}{|c|}{ Completion point reached under enhanced framework } \\
\hline Benin & Jul. 00 & Mar. 03 & 150 & & 265 & 77 & 189 & 24 & 84 & 31 & 460 \\
\hline Bolivia & & & & & 1,302 & 425 & 876 & 84 & 194 & & 2,060 \\
\hline original framework & Sep. 97 & Sep. 98 & 225 & & 448 & 157 & 291 & 29 & 54 & 14 & 760 \\
\hline enhanced framework & $\mathrm{Feb} .00$ & Jun. 01 & 150 & & 854 & 268 & 585 & 55 & 140 & 30 & 1,300 \\
\hline Burkina Faso & & & & & 553 & 83 & 469 & 57 & 231 & & 930 \\
\hline original framework & Sep. 97 & Jul. 00 & 205 & & 229 & 32 & 196 & 22 & 91 & 27 & 400 \\
\hline enhanced framework & Jul. 00 & Apr. 02 & 150 & & 195 & 35 & 161 & 22 & 79 & 30 & 300 \\
\hline topping-up & $\ldots$ & Apr. 02 & 150 & & 129 & 16 & 112 & 14 & 61 & 24 & 230 \\
\hline Cameroon & Oct. 00 & Apr. 06 & 150 & & 1,267 & 879 & 322 & 37 & 176 & 27 & 4,917 \\
\hline Ethiopia & & & & & 1,982 & 637 & 1,315 & 60 & 832 & & 3,275 \\
\hline enhanced framework & Nov. 01 & Apr. 04 & 150 & & 1,275 & 482 & 763 & 34 & 463 & 47 & 1,941 \\
\hline topping-up & & Apr. 04 & 150 & & 707 & 155 & 552 & 26 & 369 & 31 & 1,334 \\
\hline Ghana & Feb. 02 & Jul. 04 & 144 & 250 & 2,186 & 1,084 & 1,102 & 112 & 781 & 56 & 3,500 \\
\hline Guyana & & & & & 591 & 223 & 367 & 75 & 68 & & 1,354 \\
\hline original framework & Dec. 97 & May 99 & 107 & 280 & 256 & 91 & 165 & 35 & 27 & 24 & 634 \\
\hline enhanced framework & Nov. 00 & Dec-03 & 150 & 250 & 335 & 132 & 202 & 40 & 41 & 40 & 719 \\
\hline Honduras & Jul. 00 & Mar-05 & 110 & 250 & 556 & 215 & 340 & 30 & 98 & 18 & 1,000 \\
\hline Madagascar & Dec. 00 & Oct-04 & 150 & & 836 & 474 & 362 & 19 & 252 & 40 & 1,900 \\
\hline Malawi & & & & & 1,057 & 171 & 886 & 45 & 622 & & 1,628 \\
\hline enhanced framework & Dec. 00 & Aug- 06 & 150 & & 646 & 164 & 482 & 30 & 333 & 44 & 1,025 \\
\hline topping-up & & Aug- 06 & 150 & & 411 & 7 & 404 & 15 & 289 & 35 & 603 \\
\hline Mali & & & & & 539 & 169 & 370 & 59 & 185 & & 895 \\
\hline original framework & Sep. 98 & Sep. 00 & 200 & & 121 & 37 & 84 & 14 & 43 & 9 & 220 \\
\hline enhanced framework & Sep. 00 & Mar. 03 & 150 & & 417 & 132 & 285 & 45 & 143 & 29 & 675 \\
\hline Mauritania & Feb. 00 & Jun. 02 & 137 & 250 & 622 & 261 & 361 & 47 & 100 & 50 & 1,100 \\
\hline Mozambique & & & & & 2,023 & 1,270 & 753 & 143 & 443 & & 4,300 \\
\hline original framework & Apr. 98 & Jun. 99 & 200 & & 1,717 & 1,076 & 641 & 125 & 381 & 63 & 3,700 \\
\hline enhanced framework & Apr. 00 & Sep. 01 & 150 & & 306 & 194 & 112 & 18 & 62 & 27 & 600 \\
\hline Nicaragua & Dec. 00 & Jan. 04 & 150 & & 3,308 & 2,175 & 1,134 & 82 & 191 & 73 & 4,500 \\
\hline Niger & & & & & 663 & 235 & 428 & 42 & 240 & & 1,190 \\
\hline enhanced framework & Dec. 00 & Apr. 04 & 150 & & 521 & 211 & 309 & 28 & 170 & 53 & 944 \\
\hline topping-up & $\ldots$ & Apr. 04 & 150 & & 143 & 23 & 119 & 14 & 70 & 25 & 246 \\
\hline Rwanda & & & & & 696 & 65 & 631 & 63 & 383 & & 1,316 \\
\hline enhanced framework & Dec. 00 & Apr 05 & 150 & & 452 & 56 & 397 & 44 & 228 & 71 & 839 \\
\hline topping-up & $\ldots$ & Apr 05 & 150 & & 243 & 9 & 235 & 20 & 154 & 53 & 477 \\
\hline Senegal & Jun. 00 & Apr. 04 & 133 & 250 & 488 & 212 & 276 & 45 & 124 & 19 & 850 \\
\hline Tanzania & Apr. 00 & Nov. 01 & 150 & & 2,026 & 1,006 & 1,020 & 120 & 695 & 54 & 3,000 \\
\hline Uganda & & & & & 1,003 & 183 & 820 & 160 & 517 & & 1,950 \\
\hline original framework & Apr. 97 & Apr. 98 & 202 & & 347 & 73 & 274 & 69 & 160 & 20 & 650 \\
\hline enhanced framework & Feb. 00 & May 00 & 150 & & 656 & 110 & 546 & 91 & 357 & 37 & 1,300 \\
\hline Zambia & Dec. 00 & Apr-05 & 150 & & 2,499 & 1,168 & 1,331 & 602 & 493 & 63 & 3,900 \\
\hline \multicolumn{12}{|c|}{ Decision point reached under enhanced framework } \\
\hline Burundi & Aug. 05 & Floating & 150 & & 826 & 124 & 701 & 28 & 425 & 92 & 1,465 \\
\hline Chad & May. 01 & Floating & 150 & & 170 & 35 & 134 & 18 & 68 & 30 & 260 \\
\hline Congo, Democratic Rep. of & Jul. 03 & Floating & 150 & & 6,311 & 3,837 & 2,474 & 472 & 831 & 80 & 10,389 \\
\hline Congo Rep. of & Mar. 06 & Floating & & 250 & 1,679 & 1,561 & 118 & 8 & 49 & 32 & 2,881 \\
\hline Gambia, The & Dec. 00 & Floating & 150 & & 67 & 17 & 49 & 2 & 22 & 27 & 90 \\
\hline Guinea & Dec. 00 & Floating & 150 & & 545 & 215 & 328 & 31 & 152 & 32 & 800 \\
\hline Guinea-Bissau & Dec. 00 & Floating & 150 & & 416 & 212 & 204 & 12 & 93 & 85 & 790 \\
\hline São Tomé and Príncipe & Dec. 00 & Floating & 150 & & 97 & 29 & 68 & - & 24 & 83 & 200 \\
\hline Sierra Leone & Mar. 02 & Floating & 150 & & 600 & 205 & 354 & 123 & 122 & 80 & 950 \\
\hline Total assistance provided/committed & & & & & 35,170 & 17,248 & 17,783 & $2,6035 /$ & 8,494 & & 61,849 \\
\hline
\end{tabular}

Sources: IMF and World Bank Board decisions, completion point documents, decision point documents, preliminary HIPC documents, and staff calculations.

1/ Assistance levels are at countries' respective decision or completion points, as applicable.

2/ In percent of the net present value of debt at the decision or completion point (as applicable), after the full use of traditional debt-relief mechanisms.

3/ Côte d'Ivoire reached its decision point under the original framework in March 1998. The total amount of assistance committed thereunder was US\$345 million in NPV terms.

4/ Nonreschedulable debt to non-Paris Club official bilateral creditors and the London Club, which was already subject to a highly concessional restructuring, is excluded from the NPVof debt at the completion point in the calculation of this ratio.

5/ Equivalent to SDR 1,757 million at an SDR/USD exchange rate of 0.6749, as of September 26, 2006

6/ It is suggested that enhanced HIPC relief for Côte d'Ivoire overtake the commitments made under the original HIPC framework. 
Table A9. Haiti: Possible Delivery of IMF Assistance under the Enhanced HIPC Initiative, FY2007-2017 1/

(In millions of U.S. dollars, unless otherwise indicated)

\begin{tabular}{|c|c|c|c|c|c|c|c|c|c|c|c|}
\hline & FY2007 & FY2008 & FY2009 & FY2010 & FY2011 & FY2012 & FY2013 & FY2014 & FY2015 & FY2016 & FY2017 \\
\hline \multicolumn{12}{|l|}{ (Based on the US\$/SDR exchange rate as of September 27, 2006) } \\
\hline Delivery schedule of IMF assistance (in percent of the total assistance) & 2.0 & 3.5 & 3.5 & 3.5 & 3.5 & 2.0 & 15.0 & 15.0 & 15.0 & 15.0 & 22.0 \\
\hline Debt Service due on IMF obligations 2/ & $0.5^{3 /}$ & 0.6 & 0.6 & 0.6 & 0.6 & 4.7 & 8.9 & 8.8 & 8.8 & 8.7 & 4.5 \\
\hline Principal & - & - & - & - & - & 4.2 & 8.3 & 8.3 & 8.3 & 8.3 & 4.2 \\
\hline Interest and charges & 0.5 & 0.6 & 0.6 & 0.6 & 0.6 & 0.6 & 0.6 & 0.5 & 0.5 & 0.4 & 0.4 \\
\hline of which, PRGF interest & 0.1 & 0.2 & 0.2 & 0.2 & 0.2 & 0.2 & 0.2 & 0.1 & 0.1 & 0.0 & 0.0 \\
\hline IMF assistance--deposits into Haiti's Umbrella Account & \multirow{2}{*}{0.0624} & \multirow{2}{*}{\multicolumn{2}{|c|}{$\begin{array}{l}0.109^{4 /} \\
2.948\end{array}$}} & & & & & & & & \\
\hline $\begin{array}{l}\text { Interim assistance } \\
\text { Completion point assistance 5/ }\end{array}$ & & & & & & & & & & & \\
\hline IMF assistance--drawdown schedule from Haiti's Umbrella Account & 0.1 & 0.1 & 0.1 & 0.1 & 0.1 & 0.6 & 0.7 & 0.7 & 0.6 & 0.5 & 0.7 \\
\hline IMF assistance without interest & 0.1 & 0.1 & 0.1 & 0.1 & 0.1 & 0.1 & 0.5 & 0.5 & 0.5 & 0.5 & 0.7 \\
\hline Estimated interest earnings $6 /$ & 0.0 & 0.0 & 0.0 & 0.0 & 0.0 & 0.6 & 0.2 & 0.2 & 0.1 & 0.1 & 0.0 \\
\hline Debt service due on current IMF obligations after IMF assistance & 0.4 & 0.5 & 0.5 & 0.5 & 0.5 & 4.1 & 8.2 & 8.2 & 8.2 & 8.2 & 3.8 \\
\hline \multirow{2}{*}{$\begin{array}{l}\text { Share of debt service due on IMF obligations covered by } \\
\text { IMF assistance (in percent) }\end{array}$} & & & & & & & & & & & \\
\hline & 12.5 & 18.8 & 18.4 & 18.4 & 18.4 & 13.3 & 7.9 & 7.6 & 6.3 & 6.1 & 15.9 \\
\hline $\begin{array}{l}\text { Proportion (in percent) of each repayment falling due } \\
\text { during the period to be paid by IMF Initiative assistance from the } \\
\text { principial deposited in Umbrella Account }\end{array}$ & $54.2^{4 /}$ & $52.5^{4 /}$ & $52.6^{4 /}$ & $52.5^{4 /}$ & $52.5^{4 /}$ & 1.5 & 5.6 & 5.6 & 5.6 & 5.6 & 16.5 \\
\hline \multicolumn{12}{|l|}{$\begin{array}{l}\text { Memorandum items: } \\
\text { (Based on debt service data and exchange rates as of end-September 2005) }\end{array}$} \\
\hline Debt service due on IMF obligations (in millions of U.S. dollars) 3/ & 0.5 & 0.6 & 0.6 & 0.6 & 0.6 & 4.7 & 8.9 & 8.8 & 8.8 & 8.7 & 4.5 \\
\hline \multirow{2}{*}{$\begin{array}{l}\text { Debt service due on current IMF obligations after IMF assistance } \\
\text { (in percent of current year exports of goods and nonfactor services) }\end{array}$} & 0.4 & 0.5 & 0.5 & 0.5 & 0.5 & 4.1 & 8.2 & 8.2 & 8.2 & 8.2 & 3.8 \\
\hline & 0.1 & 0.1 & 0.1 & 0.1 & 0.0 & 0.4 & 0.7 & 0.7 & 0.7 & 0.6 & 0.3 \\
\hline
\end{tabular}

Source: Fund staff estimates and projections.

1/ Total IMF assistance under the enhanced HIPC Initiative is US\$ 3.120 million in NPV terms calculated on the basis of data available at the decision point, excluding interest earned on Haiti's account and on committed but undisbursed amounts as described in footnotes 5 and 6 . Assistance assumed to be delivered each fiscal year. Fiscal year ends in September.

2/ Forthcoming obligations estimated based on schedules in effect as of November 8,2006 , reflecting first disbursement under the new PRGF arrangement. Interest obligations include net SDR charges and assessments.

3/ Debt service for FY2007 are obligations from November 8, 2006 onwards.

4/ The first delivery of interim assistance will be deposited into Haiti's account at the expected decision point in November 2006 to cover PRGF interest obligations falling due to the Fund over the next 12 months. HIPC assistance is expected to cover PRGF interest obligations falling due between December 2006 and December 2011 as there are no principal obligations falling due to the Fund until May 2012.

5/Most of the IMF's grant HIPC assistance assumed to be disbursed into Haiti's account at the assumed completion point in September 2008, which is reflected in the calculation of interest.

6/ Includes estimated interest earnings on: (a) amounts held in Haiti's Umbrella Account; and (b) up to the completion point, amounts committed but not yet disbursed. The projected interest earnings are estimated based on assumed interest rates which are gradually rising to 5 percent in 2011 ; actual interest earnings may be higher or lower. Interest accrued during a calendar year will be used toward the first repayment obligation(s) falling due in the following calendar year except in the final year, when it will be used toward payment of the final obligation(s) falling due in that year. Interest accrued during the interim period will be used toward the repayment of obligations falling due during FY2012-14. 
Table A10. Haiti: Possible Delivery of IDA Assistance under the Enhanced HIPC Initiative, FY2007-2016 1/ 2/

(In millions of U.S. dollars, unless otherwise indicated)

\begin{tabular}{|c|c|c|c|c|c|c|c|c|c|c|}
\hline & FY2007 & FY2008 & FY2009 & FY2010 & FY2011 & FY2012 & FY2013 & FY2014 & FY2015 & FY2016 \\
\hline \multicolumn{11}{|c|}{ I. Debt service to IDA before HIPC Initiative assistance 3/ } \\
\hline Principal & 14.6 & 14.9 & 15.4 & 16.3 & 16.7 & 16.9 & 16.8 & 16.8 & 18.2 & 19.6 \\
\hline Interest & 3.7 & 3.6 & 3.5 & 3.3 & 3.2 & 3.1 & 3.0 & 2.8 & 2.7 & 2.6 \\
\hline \multicolumn{11}{|l|}{ II. Debt service to IDA after HIPC Initiative assistance } \\
\hline Principal & 9.2 & 14.9 & 7.7 & 11.9 & 16.7 & 16.9 & 16.8 & 16.8 & 18.2 & 19.6 \\
\hline Interest & 2.3 & 3.6 & 1.7 & 2.4 & 3.2 & 3.1 & 3.0 & 2.8 & 2.7 & 2.6 \\
\hline III. Total IDA assistance under the HIPC Initiative & 6.7 & 0.0 & 9.4 & 5.4 & 0.0 & 0.0 & 0.0 & 0.0 & 0.0 & 0.0 \\
\hline $\begin{array}{l}\text { IV. Percentage of debt service to IDA } \\
\text { covered by HIPC Initiative assistance }\end{array}$ & 36.7 & $\ldots \ldots$ & 50.0 & 27.6 & $\cdots$ & $\ldots$. & $\ldots \ldots$ & $\ldots$ & $\ldots$. & ...... \\
\hline
\end{tabular}

Memorandum Item:

Total nominal assistance

21.5

Source: World Bank staff estimates and projections.

$1 /$ Fiscal year ends in September.

(/)

de the direct impact of the concessional rescheduling of arrears in early 2005 .

3/ Principal and interest payments due to IDA correspond to prorated projections based on the disbursed and outstanding debt as of end-September 2005, converted into U.S. dollars using the exchange rate as of endSeptember 2005 . 
Table A11. Haiti: Long-Term Macroeconomic Assumptions, 2005-25 Fiscal Year Ending September 30

\begin{tabular}{|c|c|c|c|c|c|c|c|c|c|c|c|c|c|c|c|c|c|c|c|c|c|c|c|}
\hline & 2005 & 2006 & 2007 & 2008 & 2009 & 2010 & 2011 & 2012 & 2013 & 2014 & 2015 & 2016 & 2017 & 2018 & 2019 & 2020 & 2021 & 2022 & 2023 & 2024 & 2025 & $\begin{array}{l}\text { Averat } \\
2006-15\end{array}$ & $\begin{array}{l}\text { ges } \\
\text { 2016-25 }\end{array}$ \\
\hline & & & & & & & (Annual & percentage & change) & & & & & & & & & & & & & & \\
\hline \multicolumn{24}{|l|}{ National income and prices } \\
\hline $\begin{array}{l}\text { GDP Pat constatt prices } \\
\text { GDP deflator }\end{array}$ & $\begin{array}{l}1.8 \\
17.6\end{array}$ & $\begin{array}{r}2.5 \\
13.9\end{array}$ & $\begin{array}{l}4.0 \\
8.1\end{array}$ & $\begin{array}{l}4.0 \\
8.0\end{array}$ & $\begin{array}{l}4.0 \\
7.3\end{array}$ & $\begin{array}{l}4.0 \\
6.7\end{array}$ & $\begin{array}{l}4.0 \\
5.7\end{array}$ & $\begin{array}{l}4.0 \\
5.0\end{array}$ & $\begin{array}{l}4.0 \\
5.0\end{array}$ & $\begin{array}{l}4.0 \\
5.0\end{array}$ & $\begin{array}{l}4.5 \\
5.0\end{array}$ & $\begin{array}{l}4.5 \\
50\end{array}$ & $\begin{array}{l}4.5 \\
50\end{array}$ & $\begin{array}{l}4.5 \\
50\end{array}$ & $\begin{array}{l}4.5 \\
5.0\end{array}$ & $\begin{array}{l}4.5 \\
50\end{array}$ & $\begin{array}{l}4.5 \\
50\end{array}$ & $\begin{array}{l}4.5 \\
50\end{array}$ & $\begin{array}{l}4.5 \\
5.0\end{array}$ & $\begin{array}{l}4.5 \\
5.0\end{array}$ & $\begin{array}{l}4.5 \\
50\end{array}$ & $\begin{array}{l}3.7 \\
79\end{array}$ & $\begin{array}{l}4.5 \\
50\end{array}$ \\
\hline Real GDP per capita (percentage change, local currency) & -0.2 & 0.8 & 2.2 & 2.3 & 2.3 & 2.3 & 2.3 & 2.3 & 2.4 & 2.4 & 2.9 & 3.1 & 3.1 & 3.1 & 3.2 & 3.2 & 3.3 & 3.3 & 3.3 & 3.3 & 3.3 & 2.0 & 3.2 \\
\hline Consumer prices (end of period) & 14.8 & 12.4 & 8.0 & 8.0 & 7.0 & 6.0 & 5.0 & 5.0 & 5.0 & 5.0 & 5.0 & 5.0 & 5.0 & 5.0 & 5.0 & 5.0 & 5.0 & 5.0 & 5.0 & 5.0 & 5.0 & 7.4 & 5.0 \\
\hline \multicolumn{24}{|l|}{ External sector } \\
\hline Exports of goods and non-factor services & 17.1 & 5.7 & 9.5 & 10.5 & 8.0 & 9.2 & 7.7 & 6.2 & 6.3 & 6.5 & 6.7 & 6.8 & 6.9 & 7.0 & 7.0 & 7.1 & 7.2 & 7.3 & 7.4 & 7.5 & 7.6 & 8.5 & 7.2 \\
\hline Imports of goods and non-factor services & 13.7 & 14.0 & 12.8 & 5.6 & 6.2 & 7.8 & 5.3 & 5.8 & 6.0 & 6.1 & 6.3 & 6.2 & 6.1 & 6.1 & 6.0 & 6.0 & 6.0 & 5.9 & 5.9 & 5.9 & 5.9 & 8.1 & 6.0 \\
\hline \multicolumn{24}{|l|}{ Central government } \\
\hline Total revenue and grants & 54.5 & 20.5 & 28.4 & 13.4 & 14.4 & 12.7 & 13.4 & 10.1 & 10.1 & 10.1 & 10.6 & 10.6 & 10.4 & 10.8 & 10.7 & 10.5 & 10.4 & 10.3 & 10.4 & 10.5 & 10.6 & 18.0 & 10.5 \\
\hline $\begin{array}{l}\text { Central governmentr revenune } 1 / / \\
\text { Central governmente texenditure }\end{array}$ & 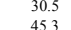 & $\begin{array}{l}23.7 \\
267\end{array}$ & $\begin{array}{l}9.2 \\
309\end{array}$ & $\begin{array}{l}18.0 \\
129\end{array}$ & 16.9 & $\begin{array}{l}14.0 \\
138\end{array}$ & $\begin{array}{l}14.8 \\
12.5\end{array}$ & $\begin{array}{l}11.8 \\
10.0\end{array}$ & $\begin{array}{ll}11.7 \\
100\end{array}$ & $\begin{array}{c}11.7 \\
9.9\end{array}$ & $\begin{array}{l}12.1 \\
105\end{array}$ & $\begin{array}{l}12.1 \\
105\end{array}$ & $\begin{array}{l}12.0 \\
105\end{array}$ & 12.0 & 11.9 & 11.9 & 11.8 & 11.8 & 11.7 & 11.7 & 11.7 & 15.8 & 11.9 \\
\hline \multirow{2}{*}{\multicolumn{24}{|c|}{ (In percent of GDP, unless otherwise indicated) }} \\
\hline & & & & & & & & & & & & & & & & & & & & & & & \\
\hline \multicolumn{24}{|l|}{ National income } \\
\hline $\begin{array}{l}\text { Consumption } \\
\text { Privet }\end{array}$ & 99.6 & $\begin{array}{l}101.0 \\
9.8 \\
9.8\end{array}$ & 98.9 & 97.4 & 97.0 & 96.9 & 96.1 & 95.9 & 95.9 & 95.8 & 95.6 & 95.5 & 95.2 & 95.0 & 94.7 & 94.4 & 94.0 & 93.6 & 93.3 & 92.8 & 92.4 & 97.3 & 94.1 \\
\hline $\begin{array}{l}\text { Private } \\
\text { Public }\end{array}$ & 93.3 & 93.8 & 91.9 & 90.1 & 89.4 & 89.0 & 88.0 & 87.8 & 87.7 & 87.6 & 87.4 & 87.2 & 87.0 & 86.7 & 86.4 & 86.0 & 85.6 & 85.3 & 84.8 & 84.4 & 84.0 & 89.6 & 85.7 \\
\hline $\begin{array}{l}\text { Public } \\
\text { Investment }\end{array}$ & $\begin{array}{r}6.3 \\
27.4\end{array}$ & $\begin{array}{r}7.2 \\
28.0\end{array}$ & $\begin{array}{r}7.0 \\
31.0\end{array}$ & $\begin{array}{r}7.3 \\
31.0\end{array}$ & $\begin{array}{r}7.6 \\
31.3\end{array}$ & $\begin{array}{r}7.9 \\
31.6\end{array}$ & $\begin{array}{r}8.1 \\
31.9\end{array}$ & $\begin{array}{r}8.1 \\
31.9\end{array}$ & $\begin{array}{r}8.2 \\
32.0\end{array}$ & $\begin{array}{r}8.2 \\
32.0\end{array}$ & $\begin{array}{r}8.2 \\
32.0\end{array}$ & $\begin{array}{l}8.2 \\
32.1\end{array}$ & $\begin{array}{r}8.3 \\
32.1\end{array}$ & $\begin{array}{r}8.3 \\
32.1\end{array}$ & $\begin{array}{r}8.3 \\
32.2\end{array}$ & $\begin{array}{r}8.3 \\
32.2\end{array}$ & $\begin{array}{r}8.4 \\
32.2\end{array}$ & $\begin{array}{r}8.4 \\
32.3\end{array}$ & $\begin{array}{r}8.4 \\
32.3\end{array}$ & $\begin{array}{r}8.4 \\
32.3\end{array}$ & $\begin{array}{r}8.5 \\
32.4\end{array}$ & $\begin{array}{r}7.7 \\
30.9\end{array}$ & 8.3 \\
\hline $\begin{array}{c}\text { invessment } \\
\text { Private }\end{array}$ & $\begin{array}{l}27.4 \\
23.0\end{array}$ & 23.0 & $\begin{array}{l}31.0 \\
23.3\end{array}$ & $\begin{array}{l}31.0 \\
23.5\end{array}$ & 23.8 & $\begin{array}{l}24.0 \\
24.0\end{array}$ & 24.2 & 24.2 & $\begin{array}{l}32.0 \\
24.2\end{array}$ & $\begin{array}{l}32.0 \\
24.3\end{array}$ & $\begin{array}{l}32.0 \\
24.3\end{array}$ & 24.3 & & 24.4 & $\begin{array}{l}32.2 \\
24.4\end{array}$ & 24.4 & $\begin{array}{l}32.2 \\
24.4\end{array}$ & 24.5 & 24.5 & 24.5 & 245 & $\begin{array}{l}30.9 \\
23.8\end{array}$ & $\begin{array}{l}32.2 \\
244\end{array}$ \\
\hline Public & 4.4 & 5.0 & 7.8 & 7.5 & 7.6 & 7.6 & 7.7 & 7.7 & 7.7 & 7.7 & 7.7 & 7.8 & 7.8 & 7.8 & 7.8 & 7.8 & 7.8 & 7.8 & 7.8 & 7.8 & 7.8 & 7.1 & $\begin{array}{l}2.47 \\
78\end{array}$ \\
\hline GDP per capita (US dollars) & 488.6 & 527.5 & 575.1 & 616.6 & 641.3 & 669.8 & 699.8 & 730.2 & 762.0 & 795.4 & 834.5 & 877.1 & 922.2 & 969.6 & 1019.7 & 1072.6 & 1129.2 & 1188.9 & 1252.0 & 1318.6 & 1388.9 & 667.3 & 1113.9 \\
\hline \multicolumn{24}{|l|}{ External sector } \\
\hline $\begin{array}{l}\text { Exports of goods an } \\
\text { Imports of foods an }\end{array}$ & $\begin{array}{l}13.9 \\
40.9\end{array}$ & $\begin{array}{l}13.3 \\
424\end{array}$ & $\begin{array}{l}13.2 \\
43.1\end{array}$ & $\begin{array}{l}13.3 \\
418\end{array}$ & $\begin{array}{l}13.6 \\
419\end{array}$ & $\begin{array}{l}14.0 \\
426\end{array}$ & $\begin{array}{l}14.2 \\
422\end{array}$ & $\begin{array}{l}14.2 \\
42.1\end{array}$ & $\begin{array}{l}14.3 \\
42 .\end{array}$ & $\begin{array}{l}14.3 \\
422\end{array}$ & $\begin{array}{l}14.4 \\
42 .\end{array}$ & $\begin{array}{l}14.4 \\
41.9\end{array}$ & $\begin{array}{l}14.4 \\
418\end{array}$ & $\begin{array}{l}14.5 \\
416\end{array}$ & 14.6 & 14.7 & 14.8 & 14.9 & 15.0 & 15.1 & 15.3 & 13.9 & 14.8 \\
\hline $\begin{array}{l}\text { Imports of goodd and non-factor services } \\
\text { External current account balance 1/ }\end{array}$ & $\begin{array}{l}40.8 \\
-6.3\end{array}$ & $\begin{array}{l}42.4 \\
-7.5\end{array}$ & & $\begin{array}{l}41.8 \\
-8.0\end{array}$ & & 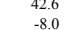 & & $\begin{array}{l}42.1 \\
-8.1\end{array}$ & -8.1 & $\begin{array}{l}42.2 \\
-8.4\end{array}$ & ${ }_{-8.2}^{42.1}$ & $\begin{array}{l}41.9 \\
-7.9\end{array}$ & $\begin{array}{l}41.8 \\
-7.5\end{array}$ & $\begin{array}{ll}41.6 \\
-7.2\end{array}$ & $\begin{array}{l}41.4 \\
-7.0\end{array}$ & 41.2 & 41.0 & 40.8 & 40.5 & & 40.0 & 42.1 & 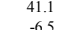 \\
\hline 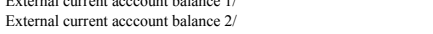 & $\begin{array}{r}-6.3 \\
1.3\end{array}$ & $\begin{array}{l}-7.5 \\
-0.1\end{array}$ & $\begin{array}{l}-9.5 \\
-1.0\end{array}$ & $\begin{array}{l}-8.0 \\
-0.5\end{array}$ & -0.5 & $\begin{array}{l}-8.0 \\
-0.7\end{array}$ & $\begin{array}{l}-7.9 \\
-0.6\end{array}$ & $\begin{array}{l}-8.1 \\
-1.2\end{array}$ & $\begin{array}{l}-8.3 \\
-1.7\end{array}$ & $\begin{array}{l}-8.4 \\
-2.1\end{array}$ & $\begin{array}{l}-8.2 \\
-2.2\end{array}$ & $\begin{array}{l}-7.1 \\
-2.1\end{array}$ & $\begin{array}{l}-7.5 \\
-2.0\end{array}$ & $\begin{array}{l}-7.2 \\
-2.1\end{array}$ & $\begin{array}{l}-7.0 \\
-2.0\end{array}$ & -6.9 & -6.8 & -6.6 & $\begin{array}{l}-5.7 \\
-1.5\end{array}$ & $\begin{array}{l}-5.5 \\
-1.4\end{array}$ & $\begin{array}{ll}-5.2 \\
-1.3\end{array}$ & $\begin{array}{l}-8.0 \\
-0.9\end{array}$ & $\begin{array}{l}-6.5 \\
-1.8\end{array}$ \\
\hline Liquid gross reserves (in months of imports of goods and services) & 1.6 & 2.0 & 2.1 & 2.5 & 2.8 & 3.1 & 3.3 & 3.3 & 3.3 & 3.3 & 3.3 & 3.3 & 3.3 & 3.3 & 3.3 & 3.3 & 3.3 & 3.3 & 3.3 & 3.3 & 3.3 & 2.8 & 3.3 \\
\hline \multicolumn{24}{|l|}{ Central government } \\
\hline Central government overall balance $2 /$ & -0.7 & -1.4 & $\begin{array}{l}-1.9 \\
1.9\end{array}$ & -1.9 & -1.9 & -2.1 & -2.0 & -2.0 & -2.0 & -2.0 & -2.0 & -2.0 & -2.0 & -2.0 & -1.9 & -1.9 & -1.9 & -2.0 & -2.0 & -2.0 & -2.0 & -1.9 & -2.0 \\
\hline $\begin{array}{l}\text { Total revenue end grants } \\
\text { Central government revenue 1/ }\end{array}$ & $\begin{array}{r}13.2 \\
97\end{array}$ & $\begin{array}{l}13.6 \\
102\end{array}$ & $\begin{array}{c}15.5 \\
99\end{array}$ & $\begin{array}{l}15.6 \\
10.4\end{array}$ & $\begin{array}{l}16.0 \\
109\end{array}$ & $\begin{array}{l}16.3 \\
112 \\
112-3\end{array}$ & $\begin{array}{l}16.8 \\
117\end{array}$ & $\begin{array}{l}17.0 \\
12 .\end{array}$ & $\begin{array}{l}17.1 \\
124\end{array}$ & $\begin{array}{l}17.3 \\
127\end{array}$ & $\begin{array}{l}17.4 \\
130\end{array}$ & 17.6 & 17.7 & 17.9 & 18.1 & 18.2 & 18.3 & 18.4 & 18.6 & 18.7 & 18.9 & 16.3 & 18.2 \\
\hline $\begin{array}{l}\text { Centrag government revenenue I/ } \\
\text { Central government expenditure }\end{array}$ & $\begin{array}{l}9.7 \\
13.8\end{array}$ & $\begin{array}{l}10.2 \\
15.0\end{array}$ & $\begin{array}{l}9.9 \\
17.4\end{array}$ & $\begin{array}{l}10.4 \\
17.5\end{array}$ & $\begin{array}{l}10.9 \\
18.0\end{array}$ & $\begin{array}{l}11.2 \\
18.4\end{array}$ & $\begin{array}{l}71.7 \\
18.9 \\
\end{array}$ & $\begin{array}{l}12.1 \\
19.0\end{array}$ & $\begin{array}{l}12.4 \\
19.1\end{array}$ & $\begin{array}{l}12.7 \\
19.3\end{array}$ & $\begin{array}{l}13.0 \\
19.4\end{array}$ & $\begin{array}{l}13.3 \\
19.6\end{array}$ & $\begin{array}{l}13.6 \\
19.7\end{array}$ & $\begin{array}{l}13.9 \\
19.9\end{array}$ & $\begin{array}{l}14.2 \\
20.0\end{array}$ & $\begin{array}{l}14.3 \\
20.1\end{array}$ & $\begin{array}{l}14.8 \\
20.3\end{array}$ & $\begin{array}{l}15.1 \\
20.4\end{array}$ & $\begin{array}{l}15.4 \\
20.6\end{array}$ & 20.7 & $\begin{array}{l}16.0 \\
20.9\end{array}$ & $\begin{array}{l}1.3 \\
18.2\end{array}$ & $\begin{array}{l}14.6 \\
20.2\end{array}$ \\
\hline & & & & & & & & & & & & & & & & & & & & & & & \\
\hline
\end{tabular}

1/ Excluding grants
2/Including grants 
Table A12. Paris Club Creditors' Delivery of Debt Relief Under Bilateral Initiatives Beyond the HIPC Initiative 1/

\begin{tabular}{|c|c|c|c|c|c|c|c|}
\hline & \multirow{2}{*}{$\begin{array}{l}\text { Countries covered } \\
\text { (1) }\end{array}$} & \multicolumn{2}{|c|}{ ODA (in percent) } & \multicolumn{2}{|c|}{ Non-ODA (in percent) } & \multicolumn{2}{|c|}{ Provision of relief } \\
\hline & & $\begin{array}{r}\text { Pre-cutoff date debt } \\
\text { (2) }\end{array}$ & $\begin{array}{r}\text { Post-cutoff date debt } \\
\text { (3) }\end{array}$ & $\begin{array}{r}\text { Pre-cutoff date debt } \\
\text { (4) } \\
\end{array}$ & $\begin{array}{r}\text { Post-cutoff date debt } \\
\text { (5) }\end{array}$ & $\begin{array}{r}\text { Decision point } \\
\text { (In percent) } \\
(6)\end{array}$ & $\begin{array}{r}\text { Completion } \\
\text { point } \\
(7) \\
\end{array}$ \\
\hline Australia & HIPCs & 100 & 100 & 100 & $1002 /$ & 2/ & 2/ \\
\hline Austria & HIPCs & 100 & - & 100 & - & Case-by-case, flow & Stock \\
\hline Belgium & HIPCs & 100 & 100 & 100 & - & 100 flow & Stock \\
\hline Canada & HIPCs 3/ & $-4 /$ & -4 & 100 & 100 & 100 flow & Stock \\
\hline Denmark & HIPCs & 100 & $1005 /$ & 100 & $1005 /$ & 100 flow & Stock \\
\hline France & HIPCs & 100 & 100 & 100 & - & 100 flow $6 /$ & Stock \\
\hline Finland & HIPCs & 100 & $-7 /$ & 100 & $-7 /$ & - & - \\
\hline Germany & HIPCs & 100 & 100 & 100 & $-8 /$ & 100 flow & Stock \\
\hline Ireland & - & - & - & - & - & - & - \\
\hline Italy & HIPCs & 100 & $1009 /$ & 100 & $1009 /$ & 100 flow & Stock \\
\hline Japan & HIPCs & 100 & 100 & 100 & - & - & Stock \\
\hline Netherlands, the & HIPCs & $10010 /$ & 100 & 100 & - & $90-100$ flow $10 /$ & Stock \\
\hline Norway & HIPCs & $11 /$ & $11 /$ & $12 /$ & $12 /$ & - & - \\
\hline Russia & Case-by-case & - & - & - & - & - & Stock \\
\hline Spain & HIPCs & 100 & Case-by-case & 100 & Case-by-case & - & Stock \\
\hline Sweden & HIPCs & - & $-13 /$ & 100 & - & - & Stock \\
\hline Switzerland & HIPCs & 100 & & 100 & Case-by-case & 100 , flow $14 /$ & Stock \\
\hline United Kingdom & HIPCs & 100 & 100 & 100 & $100 \quad 15 /$ & 100 flow $15 /$ & Stock \\
\hline United States & HIPCs & 100 & 100 & 100 & $10016 /$ & 100 flow & Stock \\
\hline
\end{tabular}

Source: Paris Club Secretariat.

1/ Columns (1) to (7) describe the additional debt relief provided following a specific methodology under bilateral initiatives and need to be read as a whole for each creditor. In column (1), "HIPCs" stands for eligible countries effectively qualifying for the HIPC process. A "100 percent" mention in the table indicates that the debt relief provided under the enhanced HIPC Initiative framework will be topped up to 100 percent through a bilateral initiative.

2/ Australia: post-cutoff date non-ODA relief to apply to debts incurred before a date to be finalized; timing details for both flow and stock relief are to be finalized

3/ Canada: including Bangladesh. Canada has granted a moratorium of debt service as of January 2001 on all debt disbursed before end-March 1999 for 13 out of 17 HIPCs

with debt service due to Canada. Eligible countries are Benin, Bolivia, Cameroon, Dem. Rep. Of Congo, Ethiopia, Ghana, Guyana, Honduras, Madagascar, Rwanda, Senegal,

Tanzania, and Zambia. $100 \%$ cancellation will be granted at completion point. As of July 2004, Canada has provided completion point stock of debt cancellation for Benin,

Bolivia, Guyana, Senegal and Tanzania.

4/ 100 percent of ODA claims have already been cancelled on HIPCs, with the exception of Myanmar's debt to Canada.

5/ Denmark provides 100 percent cancellation of ODA loans and non-ODA credits contracted and disbursed before September 27, 1999.

6/ France: cancellation of 100 percent of debt service on pre-cutoff date commercial claims on the government as they fall due starting at the decision point. Once countries have reached their completion point, debt relief on ODA claims on the government will go to a special account and will be used for specific development projects.

7/ Finland: no post-COD claims

8/ Germany proposes to cancel all debts incurred before June 20, 1999 depending on a consensus within Paris Club creditors

9/ Italy: cancellation of 100 percent of all debts (pre- and post-cutoff date, ODA and non-ODA) incurred before June 20, 1999 (the Cologne Summit). At decision point, cancellation of the related amounts falling due in the interim period. At completion point, cancellation of the stock of remaining debt.

10/ The Netherlands: 100 percent ODA (pre- and post-cutoff date debt will be cancelled at decision point); for non-ODA: in some particular cases (Benin, Bolivia, Burkina Faso, Ethiopia, Ghana, Mali, Mozambique, Nicaragua, Rwanda, Tanzania, Uganda and Zambia), the Netherlands will write off 100 percent of the consolidated amounts on the flow at decision point; all other HIPCs will receive interim relief up to 90 percent reduction of the consolidated amounts. At completion point, all HIPCs will receive

100 per cent cancellation of the remaining stock of the pre-cutoff date debt.

11/ Norway has cancelled all ODA claims.

12/ Due to the current World Bank/IMF methodology for recalculating debt reduction needs at HIPC completion point, Norway has postponed the decisions on whether or not to grant $100 \%$ debt reduction until after the completion point.

13/ Sweden has no ODA claims.

14/ Switzerland: In principle 100 percent cancellation of Pre-cutoff date non-ODA debt. However, Switzerland claims the right at the decision point to forgive only 90 percent in case of major political and/or political weaknesses.

15/ United Kingdom: "beyond 100 percent" full write-off of all debts of HIPCs as of their decision points, and reimbursement at the decision point of any debt service paid before the decision point.

16/ United States: 100 percent post-cutoff date non-ODA treated on debt assumed prior to June 20, 1999 (the Cologne Summit). 


\section{APPENDiX I-GovernanCe ACTIONS AND POLICIES}

\begin{tabular}{|c|c|c|}
\hline Participation & Accountability/Oversight & Transparency \\
\hline \multicolumn{3}{|c|}{ Recently completed actions } \\
\hline $\begin{array}{l}\text { Preparation of Extended } \\
\text { Interim Cooperation } \\
\text { Framework presented at } \\
\text { July } 2006 \text { conference } \\
\text { attended by civil society } \\
\text { representatives and } \\
\text { donors. } \\
\text { Completion in } 2006 \text { of } \\
\text { diagnostic survey of } \\
\text { state of governance and } \\
\text { perception of corruption } \\
\text { in Haiti as input to } \\
\text { design of national anti- } \\
\text { corruption strategy } \\
\text { under preparation. }\end{array}$ & $\begin{array}{l}\text { Creation of Anti-Corruption Unit (ULCC) in } 2004 . \\
\text { Financial audits of EDH (electricity), TELECO } \\
\text { (telecoms) and APN (ports authority) completed; account } \\
\text { rehabilitation of EDH and TELECO completed. } \\
\text { Strengthening of supreme audit institution (CSCCA) with } \\
2006 \text { decree on its organization and functioning. } \\
\text { Consultative committee and executive secretariat of the } \\
\text { monitoring group of civil society organizations } \\
\text { established. }\end{array}$ & $\begin{array}{l}\text { Regular public dissemination of key } \\
\text { budget allocations and execution } \\
\text { information. } \\
\text { Significant reduction of discretionary } \\
\text { spending through ministerial comptes } \\
\text { courants (from } 62 \text { percent of non-salary } \\
\text { current public expenditure during } \\
\text { Oct.2003-March } 2004 \text { to less than } 10 \\
\text { percent since Sept. 2004). } \\
\text { Dissemination of summary of progress } \\
\text { reports on economic governance reforms } \\
\text { prepared by civil society organizations. } \\
\text { Creation of National Commission for } \\
\text { Public Procurement in } 2004 \text { and } 2005 \\
\text { new procurement decree; preparation of } \\
\text { standard bidding documents; publication } \\
\text { of Government contracts and supplier } \\
\text { database. }\end{array}$ \\
\hline \multicolumn{3}{|c|}{ Planned actions (HIPC Completion Point Triggers in bold) } \\
\hline $\begin{array}{l}\text { Creation of National } \\
\text { Partnership Office } \\
\text { (NEPO) and National } \\
\text { Partnership Fund to } \\
\text { promote policy dialogue } \\
\text { and coordination } \\
\text { between key education } \\
\text { sector stakeholders } \\
\text { (including non-public } \\
\text { education service } \\
\text { providers, parents' } \\
\text { associations, teachers } \\
\text { unions, government), } \\
\text { and accountability and } \\
\text { transparency in use of } \\
\text { public education funds. }\end{array}$ & $\begin{array}{l}\text { Mechanism in place for monitoring/evaluation of PRSP } \\
\text { implementation. } \\
\text { Adoption of automated mechanism to track public } \\
\text { expenditures for poverty reduction. } \\
\text { Adoption and satisfactory implementation of public } \\
\text { financing mechanism to help poor families pay for fees } \\
\text { in non-public primary schools for enrollment of } \\
\text { additional 50,000 out-of-school children. } \\
\text { Accountability for financing mechanism at school level } \\
\text { through school management committees including } \\
\text { parents' representatives. } \\
\text { Adoption of Asset Declaration Law applying to people } \\
\text { identified by Constitution and public resource } \\
\text { managers, with sanctions for non compliance. } \\
\text { Definition of system, applicability and procedures for new } \\
\text { civil service recruitments and promotions. } \\
\text { Adoption and satisfactory implementation of Anti- } \\
\text { Corruption Strategy. } \\
\text { Up-to-date preparation of Government accounts, their } \\
\text { annual audit by CSCCA and their submission to } \\
\text { Parliament; preparation and implementation of action } \\
\text { plan to address key audit findings. } \\
\text { Up-to-date annual audit of key public enterprises' } \\
\text { financial statements; preparation and satisfactory } \\
\text { implementation of action plan to address key audit } \\
\text { recommendations. }\end{array}$ & $\begin{array}{l}\text { Dissemination of PRS annual } \\
\text { progress reports. } \\
\text { Publication of quarterly reports on } \\
\text { public expenditures for poverty } \\
\text { reduction based on automated } \\
\text { tracking mechanism. } \\
\text { Oversight of public financing } \\
\text { mechanism for non-public school } \\
\text { transfers by NEPO Board and by } \\
\text { independent audit of schools receiving } \\
\text { public transfers; information on per- } \\
\text { capita allocations to schools available to } \\
\text { parents. } \\
\text { Adoption and satisfactory } \\
\text { implementation of a new procurement } \\
\text { law, promoting transparency and } \\
\text { competition in line with international } \\
\text { best practice. }\end{array}$ \\
\hline
\end{tabular}




\section{APPENDIX II-HaIti: JoInt BANK-Fund DEbT SuSTAInABILITY ANALYSIS}

The low-income country debt sustainability analysis (LIC DSA) indicates that Haiti's risk of debt distress is high, even after full delivery of HIPC debt relief and additional bilateral debt relief..$^{49}$ Debt relief from IDA under the MDRI would significantly reduce Haiti's risk of debt distress at the decision point. The inclusion of domestic debt in the debt sustainability analysis does not change the assessment of Haiti's risk of debt distress.

\section{A. Introduction}

The debt sustainability analysis presented in this appendix is based on the common standard framework for low-income countries approved by the IDA and IMF Boards in 2005. ${ }^{\mathbf{5 0}}$ It presents the projected path of Haiti's debt burden indicators under the LIC DSA methodology and draws conclusion on the forward-looking sustainability of external and public sector debt.

\section{B. Baseline Scenario}

The baseline scenario assumes the same long-run macroeconomic framework as the one underlying the HIPC debt sustainability analysis (Box 1 in the main text). Real GDP is projected to grow, on average, by 4.2 percent from FY2006 to FY2026, reflecting better security conditions, sustained political and macroeconomic stability, progress on economic governance, and improvements in social and economic infrastructure, contributing to higher private investment, including FDI. Inflation is expected to gradually decline from 12.0 percent in FY2006, stabilizing at 5.0 percent from 2011. The external current account deficit is anticipated to slowly improve from 7.6 percent of GDP in FY2006, to 5.2 percent by 2026 . The improvement would reflect, to a large extent, robust export growth combined with a slowdown of import growth.

The baseline scenario assumes HIPC interim assistance after the decision point and irrevocable debt relief starting at the completion point, assumed at end-September 2008. This is consistent with the "conditional delivery of HIPC Initiative assistance" scenario in the HIPC DSA.

\footnotetext{
49 The World Bank's Country Policy and Institutional Assessment (CPIA) rates Haiti as a poor performer. Under the joint World Bank/IMF debt sustainability framework, the corresponding thresholds are 30 percent for the NPV of debt to GDP ratio, 100 percent for the NPV of debt to exports ratio, and 15 percent for the debt service to exports ratio (Operational Framework for Debt Sustainability Framework in Low-Income Countries-Further Considerations, (see www.imf.org).

${ }^{50}$ See "Debt Sustainability in Low-Income Countries: Proposal for an Operational Framework and Policy Implications" and "Debt Sustainability in Low-Income Countries: Further Considerations on an Operational Framework and Policy Implications".
} 


\section{Box A1. Differences in Methodologies and Results Between LIC and HIPC Debt Sustainability Analysis.}

Under the LIC DSA framework, Haiti's NPV of debt-to-exports ratio is estimated at 132.6 percent at end-2005, assuming unconditional delivery of HIPC Initiative assistance. This is 17.4 percentage points lower than the NPV of debt-to-exports ratio of 150 percent obtained using the HIPC methodology, after unconditional delivery of HIPC Initiative assistance (Table AP1). Three methodological differences between the HIPC and LIC DSA frameworks can explain the differences:

- Discount rates. Under the HIPC Initiative the rates used are the six-month averages of the currency-specific long-term commercial interest reference rates (CIRRs), which correspond to a maturity of approximately ten years. These are used to calculate the NPV on a loan-by-loan basis. The LIC DSA relies on aggregate debt service projections in US dollars, using the single discount rate for the US dollar (currently approximated 5 percent), which is higher than the average discount rate used for the HIPC DSA.

- Exchange rates. The HIPC DSA uses end-September 2005 exchange rates whereas the LIC DSA is based on WEO projections. Variations after end-September 2005 have a small positive impact (2.9 percent) on the debt indicator.

- Denominator used to calculate the NPV of debt-to-exports ratios. The denominator used under the HIPC Initiative is derived as a backward-looking three-year average. The LIC DSA framework focuses on the future path of the NPV of debt-to-exports ratio, and applies current-year's exports.

Haiti: Decomposition of the decrease in the NPV of debt-to-exports ratio at end-2005

\begin{tabular}{lc}
\hline $\begin{array}{l}\text { Factors explaining the change in } \\
\text { the NPV of debt-to-exports ratio }\end{array}$ & Impact of methodological change \\
\hline HIPC methodology & $\mathbf{1 5 0 . 0}$ \\
\hline Total change & -17.4 \\
Exchange rates & 2.9 \\
Discount rate & -2.2 \\
Exports of goods and services & -18.1 \\
& \\
\hline DSA methodology & $\mathbf{1 3 2 . 6}$ \\
\hline Memorandum items: & 597 \\
Current year's exports & 525 \\
\hline
\end{tabular}




\section{External Debt Sustainability}

The baseline scenario, which assumes full delivery of HIPC Initiative assistance, indicates that Haiti is at high risk of debt distress. The NPV of debt-to-exports ratio remains above the indicative threshold (100 percent) until FY2021. However, Haiti's debt service-to-exports ratio remains below the indicative threshold (15 percent) over the entire projection period.

The sensitivity analysis suggests that the external debt indicators could rapidly deteriorate if confronted by adverse shocks (see Table AP2). The sensitivity analysis examines the impact on debt indicators of permanent changes to baseline assumptions (alternative scenarios) as well as of temporary shocks to main variables (bound tests).

- The scenario based on historical averages of key variables gives the same conclusion as the baseline scenario. The NPV of debt-to-exports ratio is consistently above the threshold, but the other indicators remain below the indicative threshold over the projection period. The debt indicators under the historical scenario follow a somewhat higher trajectory than under the baseline scenario, reflecting the expected improvements in macroeconomic conditions compared to the last decade.

- Financial assistance provided under the MDRI would improve Haiti's debt situation. Including MDRI, which would reduce Haiti's debt by approximately US\$464.4 million in nominal terms, the NPV of external debt-to-exports ratio would fall below the 100 percent threshold at the completion point anticipated at endSeptember 2008.

- Participation in PetroCaribe could worsen debt sustainability, but does not lead to any additional breaches of indicative thresholds compared to the baseline scenario (see Box A2).

- The bound tests reveal some underlying vulnerabilities, particularly with respect to the export-based debt indicator. The export-based debt indicator worsens significantly in all scenarios. However, the GDP-based debt indicator remains below the indicative threshold with the exception of a combined adverse shock to all key variables (real GDP growth, export growth, US dollar GDP deflator, and non-debt creating capital inflows). The debt service indicators never breach the indicative threshold. 


\section{Box A2. The Impact on Debt Sustainability of PetroCaribe}

Under the PetroCaribe agreement, Haiti could obtain new concessional external

financing from Venezuela. The agreement was ratified by the Parliament in August. At current oil prices, the accord provides for upfront payment of 60 percent of oil imported through the accord and payments for the remaining 40 percent over 25 years with a two-year grace period at 1 percent annual interest. The underlying grant element is estimated at 49 percent at current US dollar discount rates.

Despite high concessionality, PetroCaribe could lead to a significant increase in external debt service payments in the medium and long run. The agreement does not specify the amount that could be imported under

PetroCaribe, but based on earlier

NPV of debt-to-exports ratio, PetroCaribe assessments, the staff projects that Haiti could receive about 4,500 barrels per day, or about $1 / 3$ of current oil imports. Assuming oil imports of about 1.6 millions barrels a year under the PetroCaribe agreement over the next five years (FY2007-11), with oil prices in line with WEO assumptions, Haiti would accumulate annual gross flows of concessional resources of about 0.8 percent of GDP during FY2007-11. However, from FY2012, transfers become negative. Debt service payments related to PetroCaribe would peak at about 1 percent of exports in FY2013.

The increase in the external debt service payments reflects to fact that the authorities intend to use resources from PetroCaribe will be used to

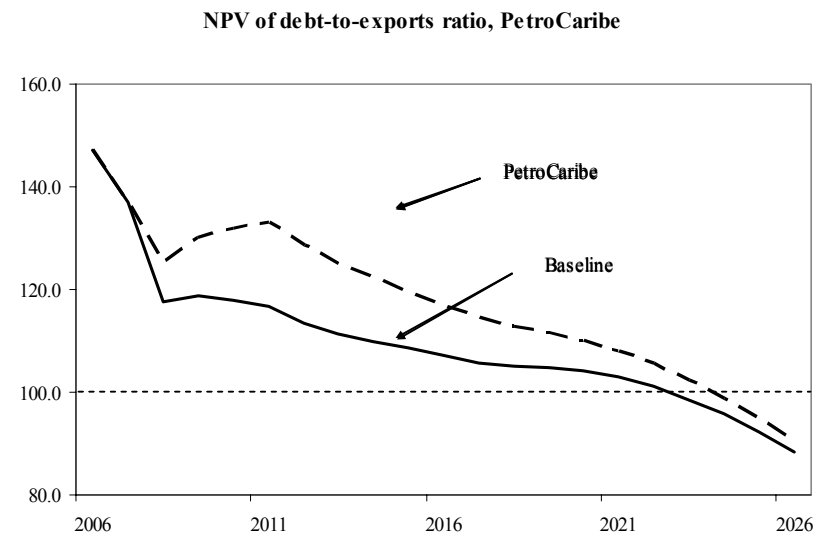
finance investment projects. It will be

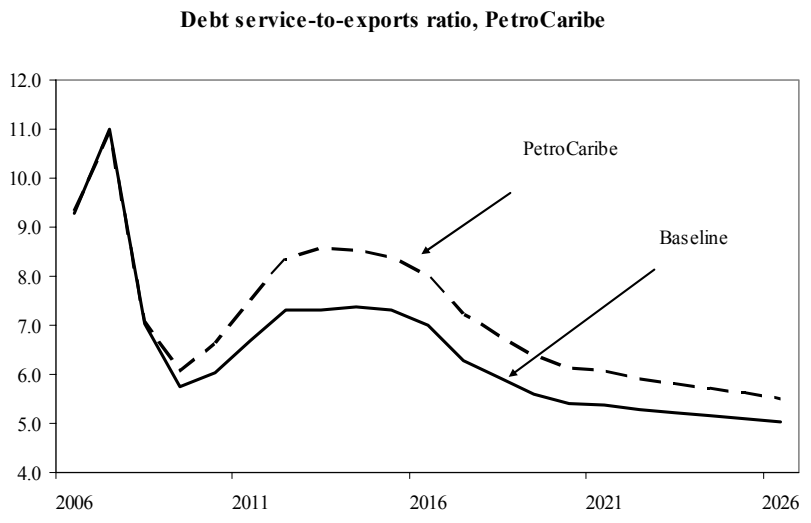
important to ensure that the returns to these projects, which can be expected to materialize in the long run, are adequate to amortize the accumulated debt. 


\section{Public Sector Debt Sustainability}

Under the baseline scenario, Haiti's public debt (including domestic debt) is expected to remain broadly constant (see Table AP3). In the short run the country is expected to continue to rely heavily on external financing, especially external grants. This, together with high revenue efforts and a slow expansion of the public sector, should contain debt-creating financing of the budget and thereby help to maintain fiscal sustainability. A relatively low initial public debt burden and the positive outlook for revenue performance and growth would allow the country to run a primary deficit of on average 1.2 percent of GDP over the long run without threatening long-term sustainability.

A projected slowdown in external grant financing is expected to be counterbalanced by higher internal revenues and a gradual increase of domestic borrowing. Domestic debt is expected to increase from about 2.0 percent of GDP in the medium term to 7.4 percent of GDP by FY2026. The expected increase in domestic debt is anticipated to contribute to the development of the domestic financial market.

The evolution of public debt remains robust under alternative scenarios and bound tests (see Table AP4). However, low growth (scenario B1) could distort the debt trajectory leading to an increase of 11 percentage points in the NPV of debt-to-GDP ratio between FY2006 and FY2026. In the short and medium-term, projected debt trends shown in the baseline scenarios are closely aligned with trends prevailing under macroeconomic assumptions in line with historical trends. Given growth and revenue projections above historical trends, debt projections divert from historical developments in the long run.

\section{E. Debt Distress Classification and Conclusion}

Haiti's risk of debt distress is high. Under the baseline scenario - which includes HIPC Initiative assistance - the NPV of debt-to-exports ratio remains above the LIC DSA threshold (100 percent) until FY2021, whereas the other debt indicators remain below the threshold over the projection period. The sensitivity analysis has highlighted the fact that Haiti's external debt situation is vulnerable to shocks.

Public sector domestic debt is not projected to add significant risk to the debt outlook. Increased revenue efforts and a slow expansion of the public sector will help to maintain fiscal sustainability in the medium and long run. 
Table AP1. Haiti: External Debt Sustainability Framework, Baseline Scenario, 2006-2026 1/ (n percent of GDP, unless otherwise indicated)

\begin{tabular}{|c|c|c|c|c|c|c|c|c|c|c|c|c|c|c|c|c|c|c|}
\hline & \multicolumn{6}{|c|}{ Actual } & \multirow{2}{*}{$\begin{array}{l}\text { Historical } \\
\text { Average 6/ }\end{array}$} & \multirow{2}{*}{$\begin{array}{c}\text { Standard } \\
\text { Deviation 6/ }\end{array}$} & \multicolumn{6}{|c|}{ Projections } & \multirow[b]{2}{*}{$\begin{array}{l}2006-11 \\
\text { Average }\end{array}$} & \multirow[b]{2}{*}{2016} & \multirow[b]{2}{*}{2026} & \multirow{2}{*}{$\begin{array}{l}2012-26 \\
\text { Average }\end{array}$} \\
\hline & 2000 & 2001 & 2002 & 2003 & 2004 & 2005 & & & 2006 & 2007 & 2008 & 2009 & 2010 & 2011 & & & & \\
\hline External debt (nominal) 1/ & 28.9 & 32.6 & 35.2 & 43.9 & 38.3 & 29.5 & & & 28.0 & 25.9 & 24.6 & 25.4 & 26.1 & 26.5 & & 25.6 & 22.5 & \\
\hline $\mathrm{o} / \mathrm{w}$ public and publicly guaranteed (PPG) & 28.9 & 32.6 & 35.2 & 43.9 & 38.3 & 29.5 & & & 28.0 & 25.9 & 24.6 & 25.4 & 26.1 & 26.5 & & 25.6 & 22.5 & \\
\hline Change in external debt & 0.4 & 3.7 & 2.7 & 8.7 & -5.6 & -8.7 & & & -1.5 & -2.1 & -1.4 & 0.9 & 0.7 & 0.3 & & -0.1 & -0.9 & \\
\hline Identified net debt-creating flows & 2.2 & 4.8 & 2.0 & 7.1 & -6.0 & -8.4 & & & -1.5 & -0.2 & -0.8 & -0.9 & -0.8 & -1.0 & & 0.3 & -1.0 & \\
\hline Non-interest current account deficit & 0.6 & 1.7 & 0.6 & 1.0 & 0.8 & -1.7 & 0.3 & 1.0 & -0.3 & 0.9 & 0.3 & 0.3 & 0.4 & 0.3 & & 1.8 & 0.9 & 1.5 \\
\hline Deficit in balance of goods and services & 21.6 & 23.9 & 23.1 & 32.0 & 29.3 & 27.0 & & & 29.1 & 30.1 & 28.5 & 28.3 & 28.6 & 28.0 & & 27.5 & 24.4 & \\
\hline Exports & 12.7 & 12.3 & 12.6 & 15.8 & 14.4 & 13.9 & & & 13.3 & 13.2 & 13.3 & 13.6 & 14.0 & 14.2 & & 14.4 & 15.4 & \\
\hline Imports & 34.3 & 36.2 & 35.7 & 47.9 & 43.8 & 40.8 & & & 42.4 & 43.3 & 41.8 & 42.0 & 42.6 & 42.2 & & 41.9 & 39.8 & \\
\hline Net current transfers $($ negative $=$ inflow $)$ & -20.2 & -21.8 & -22.6 & -31.0 & -28.4 & -29.1 & -21.4 & 6.3 & -29.3 & -29.1 & -27.9 & -27.7 & -27.6 & -27.1 & & -25.1 & -23.0 & -24.5 \\
\hline Other current account flows (negative = net inflow) & -0.7 & -0.3 & 0.0 & 0.0 & -0.1 & 0.4 & & & 0.0 & -0.1 & -0.2 & -0.3 & -0.5 & -0.6 & & -0.6 & -0.5 & \\
\hline Net FDI (negative $=$ inflow) & -0.2 & -0.1 & -0.1 & -0.5 & -0.2 & -0.2 & -0.3 & 0.2 & -1.0 & -0.4 & -0.4 & -0.5 & -0.5 & -0.6 & & -0.7 & -1.2 & -0.9 \\
\hline Endogenous debt dynamics $2 /$ & 1.8 & 3.2 & 1.6 & 6.6 & -6.7 & -6.4 & & & -0.3 & -0.7 & -0.7 & -0.7 & -0.7 & -0.7 & & -0.8 & -0.7 & \\
\hline Contribution from nominal interest rate & 0.4 & 0.3 & 0.4 & 0.5 & 0.5 & 0.4 & & & 0.4 & 0.3 & 0.3 & 0.3 & 0.3 & 0.3 & & 0.3 & 0.2 & \\
\hline Contribution from real GDP growth & -0.3 & 0.3 & 0.1 & -0.2 & 1.3 & -0.6 & & & -0.7 & -1.0 & -1.0 & -0.9 & -1.0 & -1.0 & & -1.1 & -1.0 & \\
\hline Contribution from price and exchange rate changes & 1.7 & 2.5 & 1.1 & 6.2 & -8.5 & -6.3 & & & & & & & & & & & & \\
\hline Residual (3-4) 3/ & -1.9 & -1.1 & 0.7 & 1.6 & 0.4 & -0.4 & & & 0.0 & -1.9 & -0.5 & 1.7 & 1.5 & 1.3 & & -0.4 & 0.1 & \\
\hline $\mathrm{o} / \mathrm{w}$ exceptional financing & -0.2 & -0.3 & -0.8 & 0.0 & -0.6 & 1.0 & & & -0.2 & 0.8 & 0.0 & 0.0 & 0.0 & 0.0 & & 0.0 & 0.0 & \\
\hline NPV of external debt $4 /$ & $\ldots$ & $\ldots$ & $\ldots$ & $\ldots$ & $\ldots$ & 20.8 & & & 19.6 & 18.1 & 15.7 & 16.2 & 16.5 & 16.6 & & 15.4 & 13.6 & \\
\hline In percent of exports & $\ldots$ & $\ldots$ & $\ldots$ & $\ldots$ & $\ldots$ & 149.9 & & & 147.1 & 137.1 & 117.6 & 118.7 & 117.9 & 116.7 & & 107.1 & 88.3 & \\
\hline NPV of PPG external debt & ... & ... & ... & $\ldots$ & $\ldots$ & 20.8 & & & 19.6 & 18.1 & 15.7 & 16.2 & 16.5 & 16.6 & & 15.4 & 13.6 & \\
\hline In percent of exports & $\cdots$ & w & $\cdots$ & . & w & 149.9 & & & 147.1 & 137.1 & 117.6 & 118.7 & 117.9 & 116.7 & & 107.1 & 88.3 & \\
\hline Debt service-to-exports ratio (in percent) & 7.9 & 8.7 & 7.9 & 8.7 & 9.1 & 8.5 & & & 9.3 & 11.0 & 7.0 & 5.8 & 6.0 & 6.7 & & 7.0 & 5.0 & \\
\hline PPG debt service-to-exports ratio (in percent) & 7.9 & 8.7 & 7.9 & 8.7 & 9.1 & 8.5 & & & 9.3 & 11.0 & 7.0 & 5.8 & 6.0 & 6.7 & & 7.0 & 5.0 & \\
\hline Total gross financing need (millions of U.S. dollars) & 56.4 & 98.0 & 49.4 & 56.7 & 68.8 & -32.4 & & & 0.7 & 102.9 & 44.2 & 33.9 & 48.0 & 44.9 & & 194.2 & 83.2 & \\
\hline Non-interest current account deficit that stabilizes debt ratio & 0.3 & -2.0 & -2.1 & -7.7 & 6.4 & 7.0 & & & 1.2 & 3.0 & 1.6 & -0.6 & -0.3 & 0.0 & & 1.9 & 1.8 & \\
\hline \multicolumn{19}{|l|}{ Key macroeconomic assumptions } \\
\hline Real GDP growth (in percent) & 0.9 & -1.0 & -0.3 & 0.4 & -3.5 & 1.8 & 1.0 & 2.2 & 2.5 & 4.0 & 4.0 & 4.0 & 4.0 & 4.0 & 3.7 & 4.5 & 4.5 & 4.4 \\
\hline GDP deflator in US dollar terms (change in percent) & -5.6 & -8.1 & -3.2 & -15.1 & 23.9 & 19.7 & 3.7 & 12.8 & 7.1 & 6.7 & 4.9 & 1.7 & 2.1 & 2.1 & 4.1 & 1.9 & 1.9 & 1.9 \\
\hline Effective interest rate (percent) 5/ & 1.2 & 1.0 & 1.2 & 1.2 & 1.4 & 1.3 & 1.2 & 0.2 & 1.5 & 1.1 & 1.3 & 1.1 & 1.1 & 1.2 & 1.2 & 1.2 & 1.1 & 1.1 \\
\hline Growth of exports of G\&S (US dollar terms, in percent) & -4.8 & -12.0 & -1.3 & 7.2 & 8.9 & 17.1 & 11.2 & 16.3 & 5.7 & 9.5 & 10.5 & 8.0 & 9.2 & 7.7 & 8.4 & 6.8 & 7.6 & 7.0 \\
\hline Growth of imports of G\&S (US dollar terms, in percent) & 8.0 & -4.0 & -4.8 & 14.4 & 9.2 & 13.7 & 8.6 & 8.7 & 14.0 & 13.2 & 5.4 & 6.2 & 7.8 & 5.2 & 8.6 & 6.2 & 5.9 & 6.0 \\
\hline Grant element of new public sector borrowing (in percent) & & & $\ldots$ & $\ldots$ & $\ldots$ & $\ldots$ & $\ldots$ & $\ldots$ & 48.4 & 43.3 & 49.0 & 49.0 & 50.9 & 52.5 & 48.9 & 52.4 & 52.4 & 52.4 \\
\hline \multicolumn{19}{|l|}{ Memorandym item: } \\
\hline Nominal GDP (millions of US dollars) & 3953.8 & 3596.4 & 3472.2 & 2960.3 & 3537.7 & 4310.3 & & & 4733.9 & 5250.4 & 5725.7 & 6055.3 & 6430.9 & 6829.8 & & 9236.3 & 17385.3 & \\
\hline
\end{tabular}

$1 /$ Includes both public and private sector external deb.

2/ Derived as $[\mathrm{r}-\mathrm{g}-\rho(1+\mathrm{g})] /(1+\mathrm{g}+\rho+\mathrm{g} \rho)$ times previous period debt ratio, with $\mathrm{r}=$ nominal interest rate; $\mathrm{g}=$ real GDP growth rate, and $\rho=$ growth rate of GDP deflator in U.S. dollar terms.

3/ Includes exceptional financing (i.e., changes in arrears and debt relief); changes in gross foreign assets; and valuation adjustments. For projections also includes contribution from price and exchange rate changes. 5/ Current-year interest payments devided by previous period debt stock.

6/ Historical averages and standard deviations are generally derived over the past 10 years, subject to data availability. 
Table AP2. Haiti: Sensitivity Analyses for Key Indicators of Public and Publicly Guaranteed External Debt, 2006-26 (In percent)

\begin{tabular}{|c|c|c|c|c|c|c|c|c|}
\hline & \multicolumn{8}{|c|}{ Projections } \\
\hline & 2006 & 2007 & 2008 & 2009 & 2010 & 2011 & 2016 & 2026 \\
\hline \multicolumn{9}{|c|}{ NPV of debt-to-GDP ratio } \\
\hline Baseline & 20 & 18 & 16 & 16 & 17 & 17 & 15 & 14 \\
\hline \multicolumn{9}{|l|}{ A. Alternative Scenarios } \\
\hline A1. Key variables at their historical averages in 2007-26 1/ & 17 & 17 & 17 & 18 & 19 & 19 & 17 & 15 \\
\hline A2. New public sector loans on less favorable terms in $2007-262 /$ & 17 & 16 & 17 & 18 & 19 & 19 & 21 & 21 \\
\hline A3. PetroCaribe agreement & 20 & 18 & 17 & 18 & 18 & 19 & 17 & 14 \\
\hline A4. MDRI & 20 & 18 & 11 & 12 & 12 & 13 & 13 & 13 \\
\hline \multicolumn{9}{|l|}{ B. Bound Tests } \\
\hline B1. Real GDP growth at historical average minus one standard deviation in 2007-08 & 17 & 17 & 17 & 18 & 18 & 18 & 17 & 15 \\
\hline B2. Export value growth at historical average minus one standard deviation in 2007-08 3/ & 17 & 17 & 18 & 19 & 19 & 19 & 18 & 15 \\
\hline B3. US dollar GDP deflator at historical average minus one standard deviation in 2007-08 & 17 & 18 & 21 & 22 & 22 & 22 & 21 & 18 \\
\hline B4. Net non-debt creating flows at historical average minus one standard deviation in 2007-08 4/ & 17 & 23 & 29 & 29 & 29 & 29 & 26 & 19 \\
\hline B5. Combination of B1-B4 using one-half standard deviation shocks & 17 & 26 & 38 & 39 & 39 & 38 & 35 & 24 \\
\hline B6. One-time 30 percent nominal depreciation relative to the baseline in 2007 5/ & 17 & 22 & 22 & 22 & 23 & 23 & 21 & 19 \\
\hline \multicolumn{9}{|c|}{ NPV of debt-to-exports ratio } \\
\hline Baseline & 147 & 137 & 118 & 119 & 118 & 117 & 107 & 88 \\
\hline \multicolumn{9}{|l|}{ A. Alternative Scenarios } \\
\hline A1. Key variables at their historical averages in $2007-261 /$ & 130 & 125 & 129 & 132 & 133 & 135 & 117 & 101 \\
\hline A2. New public sector loans on less favorable terms in $2007-262 /$ & 130 & 121 & 124 & 129 & 133 & 136 & 143 & 139 \\
\hline A3. PetroCaribe agreement & 130 & 137 & 125 & 130 & 132 & 133 & 117 & 90 \\
\hline A4. MDRI & 147 & 137 & 83 & 86 & 87 & 89 & 87 & 83 \\
\hline \multicolumn{9}{|l|}{ B. Bound Tests } \\
\hline B1. Real GDP growth at historical average minus one standard deviation in 2007-08 & 130 & 120 & 117 & 119 & 118 & 117 & 107 & 88 \\
\hline B2. Export value growth at historical average minus one standard deviation in 2007-08 3/ & 130 & 146 & 183 & 184 & 181 & 179 & 163 & 127 \\
\hline B3. US dollar GDP deflator at historical average minus one standard deviation in 2007-08 & 130 & 120 & 117 & 119 & 118 & 117 & 107 & 88 \\
\hline B4. Net non-debt creating flows at historical average minus one standard deviation in 2007-08 4/ & 130 & 174 & 217 & 215 & 209 & 205 & 184 & 121 \\
\hline B5. Combination of B1-B4 using one-half standard deviation shocks & 130 & 183 & 255 & 252 & 246 & 240 & 215 & 140 \\
\hline B6. One-time 30 percent nominal depreciation relative to the baseline in 20075 / & 130 & 120 & 117 & 119 & 118 & 117 & 107 & 88 \\
\hline
\end{tabular}

Debt service ratio

Baseline

A. Alternative Scenarios

A1. Key variables at their historical averages in 2007-26 1/

A2. New public sector loans on less favorable terms in 2007-26

A3. PetroCaribe agreement

A4. MDRI

B. Bound Tests

B1. Real GDP growth at historical average minus one standard deviation in 2007-08

B2. Export value growth at historical average minus one standard deviation in 2007-08 3 /

B3. US dollar GDP deflator at historical average minus one standard deviation in 2007-08

B4. Net non-debt creating flows at historical average minus one standard deviation in 2007-08 4/

B5. Combination of B1-B4 using one-half standard deviation shocks

B6. One-time 30 percent nominal depreciation relative to the baseline in 20075 /

Memorandum item

Grant element assumed on residual financing (i.e., financing required above baseline) 6

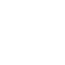


Table AP3. Haiti: Public Sector Debt Sustainability Framework, Baseline Scenario, 2003-2026

(In percent of GDP, unless otherwise indicated)

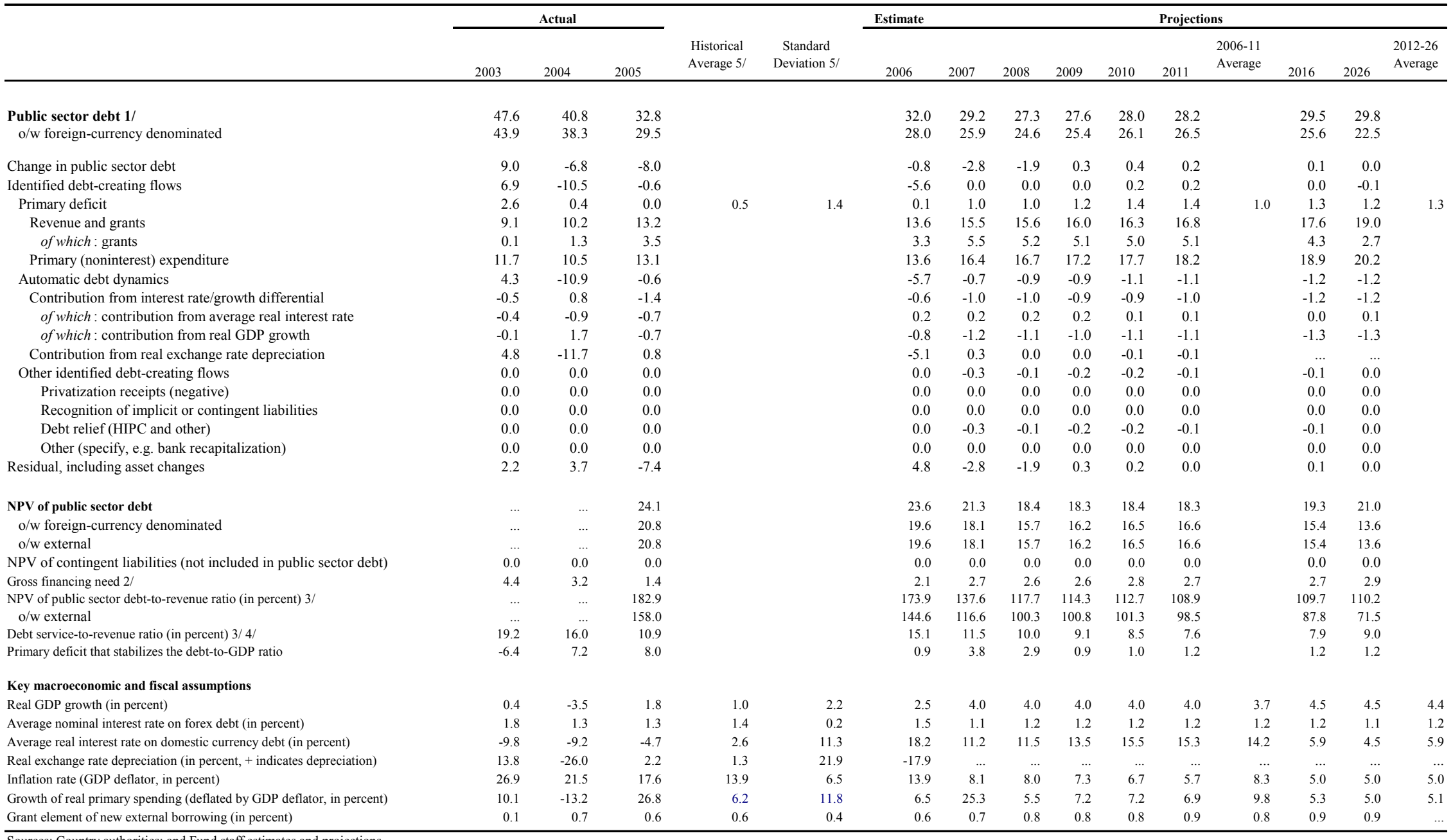

Sources: Country authorities; and Fund staff estimates and projections.

2/ Gross financing need is defined as the primary deficit plus debt service plus the stock of short-term debt at the end of the last period.

3/ Revenues including grants.

4/ Debt service is defined as the sum of interest and amortization of medium and long-term debt.

$5 /$ Historical averages and standard deviations are generally derived over the past 10 years, subject to data availability 
Table AP4. Haiti: Sensitivity Analysis for Key Indicators of Public Debt 2006-2026

\begin{tabular}{|c|c|c|c|c|c|c|c|c|}
\hline & \multicolumn{8}{|c|}{ Projections } \\
\hline & 2006 & 2007 & 2008 & 2009 & 2010 & 2011 & 2016 & 2026 \\
\hline \multicolumn{9}{|c|}{ NPV of Debt-to-GDP Ratio } \\
\hline Baseline & 24 & 21 & 18 & 18 & 18 & 18 & 19 & 21 \\
\hline \multicolumn{9}{|l|}{ A. Alternative scenarios } \\
\hline A1. Real GDP growth and primary balance are at historical averages & 24 & 22 & 19 & 19 & 19 & 19 & 21 & 28 \\
\hline A2. Primary balance is unchanged from 2006 & 24 & 21 & 17 & 17 & 16 & 16 & 14 & 11 \\
\hline A3. Permanently lower GDP growth $1 /$ & 24 & 21 & 19 & 19 & 19 & 19 & 22 & 29 \\
\hline \multicolumn{9}{|l|}{ B. Bound tests } \\
\hline B1. Real GDP growth is at historical average minus one standard deviations in 2007-2008 & 24 & 23 & 21 & 22 & 23 & 23 & 27 & 35 \\
\hline B2. Primary balance is at historical average minus one standard deviations in $2007-2008$ & 24 & 22 & 19 & 19 & 19 & 19 & 20 & 21 \\
\hline B3. Combination of B1-B2 using one half standard deviation shocks & 24 & 22 & 20 & 20 & 20 & 19 & 19 & 20 \\
\hline B4. One-time 30 percent real depreciation in 2007 & 24 & 30 & 26 & 26 & 25 & 24 & 23 & 23 \\
\hline B5. 10 percent of GDP increase in other debt-creating flows in 2007 & 24 & 27 & 23 & 23 & 23 & 23 & 23 & 24 \\
\hline \multicolumn{9}{|c|}{ NPV of Debt-to-Revenue Ratio 2/ } \\
\hline Baseline & 174 & 138 & 118 & 114 & 113 & 109 & 110 & 110 \\
\hline \multicolumn{9}{|l|}{ A. Alternative scenarios } \\
\hline A1. Real GDP growth and primary balance are at historical averages & 174 & 139 & 119 & 116 & 114 & 110 & 111 & 127 \\
\hline A2. Primary balance is unchanged from 2006 & 174 & 135 & 112 & 105 & 99 & 92 & 78 & 60 \\
\hline A3. Permanently lower GDP growth $1 /$ & 174 & 138 & 119 & 116 & 116 & 113 & 122 & 151 \\
\hline \multicolumn{9}{|l|}{ B. Bound tests } \\
\hline B1. Real GDP growth is at historical average minus one standard deviations in 2007-2008 & 174 & 144 & 132 & 132 & 134 & 133 & 151 & 181 \\
\hline B2. Primary balance is at historical average minus one standard deviations in $2007-2008$ & 174 & 141 & 123 & 119 & 118 & 114 & 114 & 113 \\
\hline B3. Combination of B1-B2 using one half standard deviation shocks & 174 & 142 & 125 & 120 & 117 & 111 & 106 & 101 \\
\hline B4. One-time 30 percent real depreciation in 2007 & 174 & 197 & 169 & 159 & 152 & 143 & 130 & 121 \\
\hline B5. 10 percent of GDP increase in other debt-creating flows in 2007 & 174 & 172 & 149 & 144 & 141 & 136 & 133 & 124 \\
\hline \multicolumn{9}{|c|}{ Debt Service-to-Revenue Ratio 2/ } \\
\hline Baseline & 15 & 12 & 10 & 9 & 9 & 8 & 8 & 9 \\
\hline \multicolumn{9}{|l|}{ A. Alternative scenarios } \\
\hline A1. Real GDP growth and primary balance are at historical averages & 15 & 12 & 10 & 9 & 9 & 8 & 9 & 12 \\
\hline A2. Primary balance is unchanged from 2006 & 15 & 12 & 9 & 8 & 8 & 7 & 7 & 6 \\
\hline A3. Permanently lower GDP growth 1/ & 15 & 12 & 10 & 9 & 9 & 8 & 9 & 11 \\
\hline \multicolumn{9}{|l|}{ B. Bound tests } \\
\hline B1. Real GDP growth is at historical average minus one standard deviations in $2007-2008$ & 15 & 12 & 11 & 11 & 10 & 9 & 10 & 13 \\
\hline B2. Primary balance is at historical average minus one standard deviations in $2007-2008$ & 15 & 12 & 11 & 10 & 9 & 8 & 8 & 9 \\
\hline B3. Combination of B1-B2 using one half standard deviation shocks & 15 & 12 & 11 & 10 & 9 & 8 & 8 & 9 \\
\hline B4. One-time 30 percent real depreciation in 2007 & 15 & 12 & 11 & 10 & 9 & 9 & 9 & 10 \\
\hline B5. 10 percent of GDP increase in other debt-creating flows in 2007 & 15 & 12 & 17 & 10 & 9 & 8 & 8 & 10 \\
\hline
\end{tabular}

Sources: Fund staff estimates and projections.

1/ Assumes that real GDP growth is at baseline minus one standard deviation divided by the square root of 20 (i.e., the length of the projection period)

2/ Revenues are defined inclusive of grants. 
Figure AP1. Haiti: Indicators of Public and Publicly Guaranteed External Debt

Under Alternative Scenarios, 2006-2026
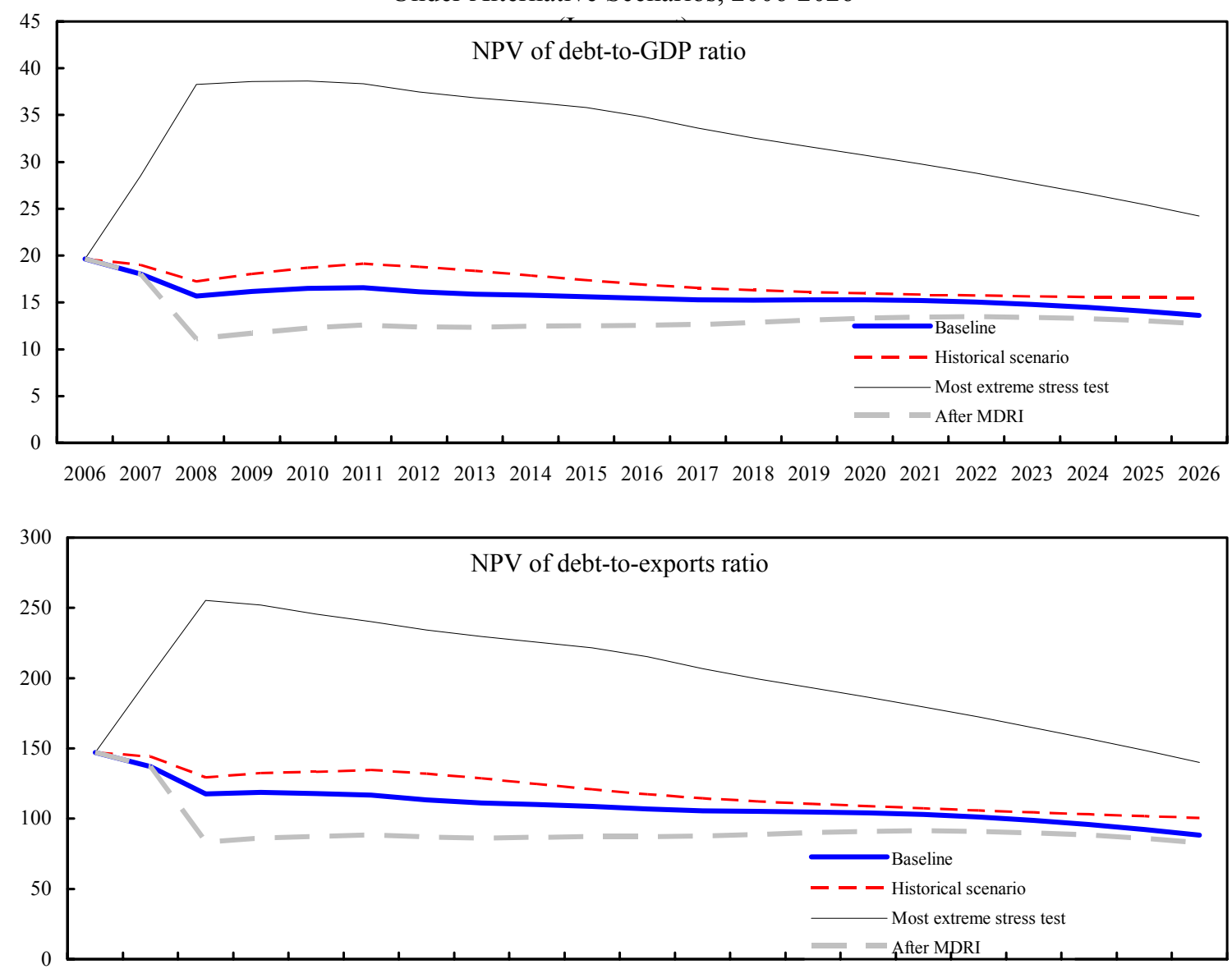

200620072008200920102011201220132014201520162017201820192020202120222023202420252026

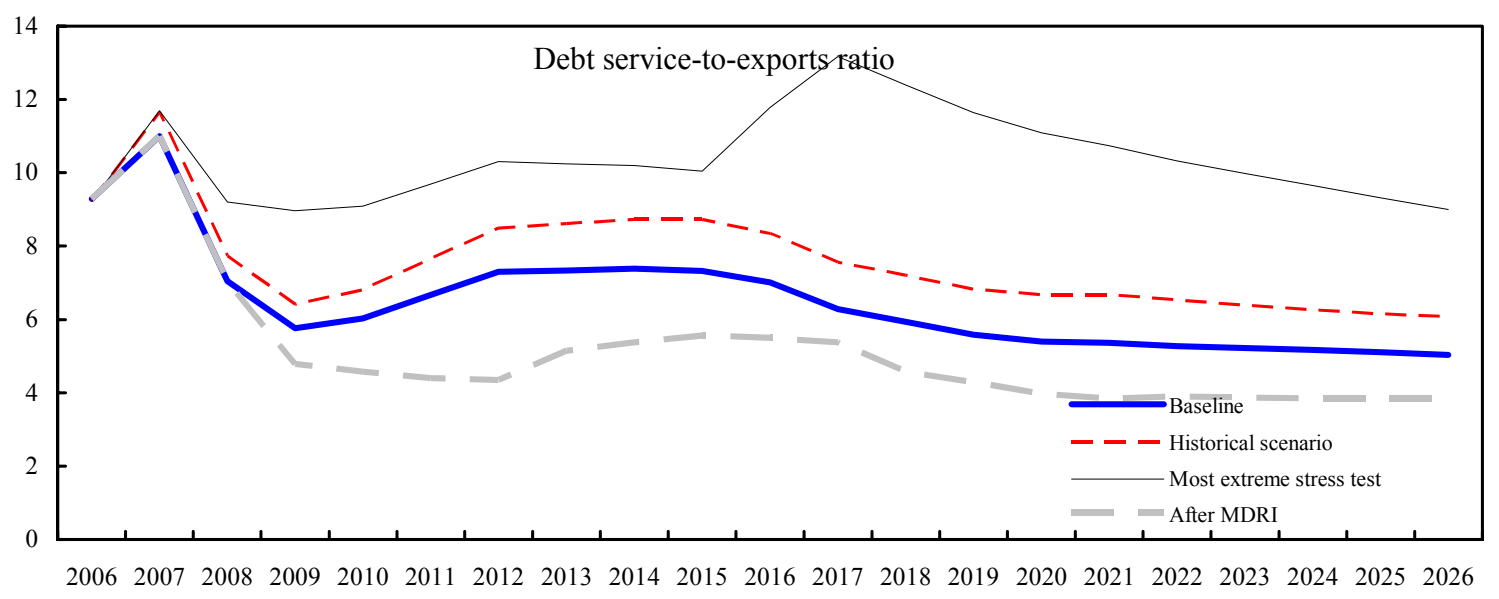

Source: Staff projections and simulations. 
Figure AP2. Haiti: Indicators of Public Debt Under Alternative Scenarios, 2006-2026 1/

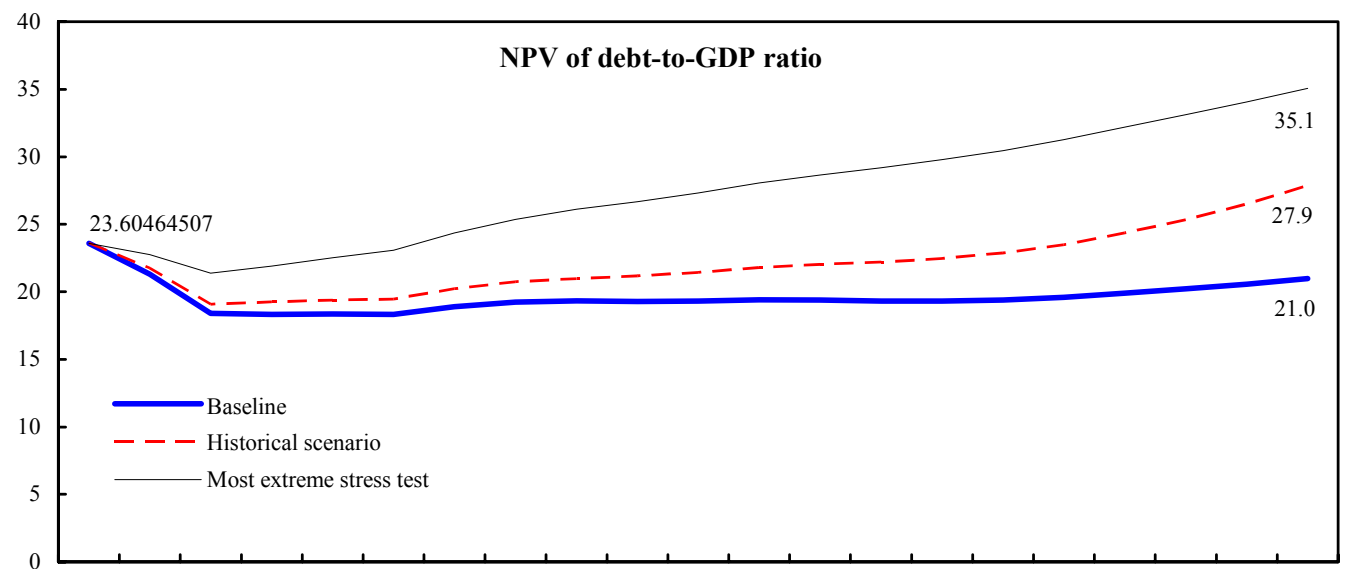

200620072008200920102011201220132014201520162017201820192020202120222023202420252026

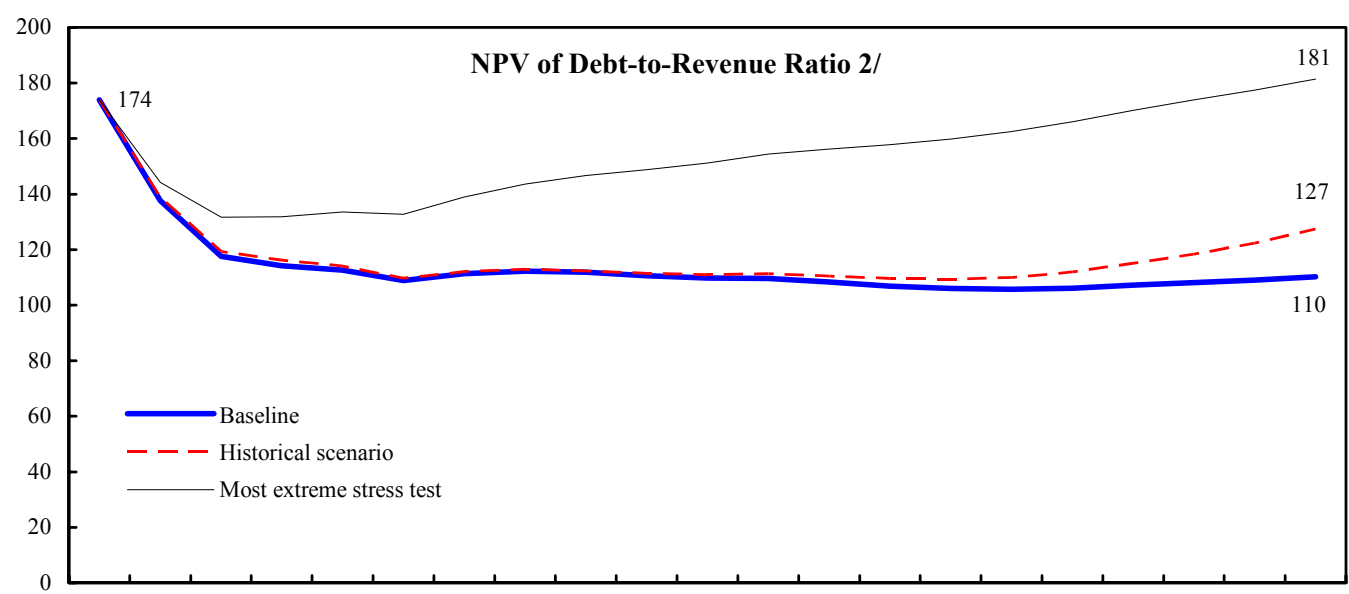

200620072008200920102011201220132014201520162017201820192020202120222023202420252026

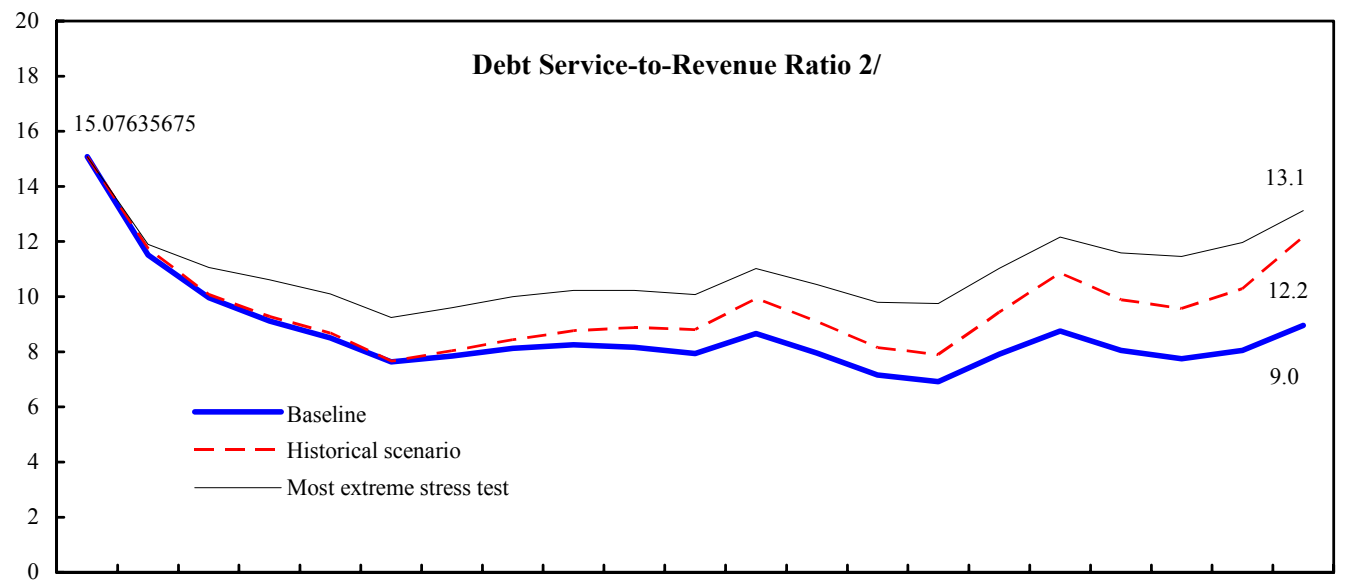

200620072008200920102011201220132014201520162017201820192020202120222023202420252026

Source: Staff projections and simulations.

1/ Most extreme stress test is test that yields highest ratio in 2016.

$2 /$ Revenue including grants. 


\section{Appendix III-Debt Management Capacity}

Currently, the Central Bank of the Republic of Haiti (Banque Centrale de la République d'Haïti, BRH) and the Ministry of Economy and Finances (Ministère de l'Économie et des Finances, MEF) are jointly responsible for debt management in Haiti. While the BRH has a relatively complete debt database, the archives of the MEF were devastated by a fire in 2002. The MEF with support from the BRH is currently rebuilding its database. Overall, the coverage of public debt (external and domestic) is appropriate. The BRH updates its database at every payment cycle, ensuring that the authorities' database is broadly in line with the creditors.

A modern debt reporting system is installed at the $\mathrm{BRH}$, while the MEF is preparing to acquire such a system. Currently, the BRH uses an old version of UNCTAD's debt management system (DMFAS, version 5.2). Both the BRH and the MEF are considering acquiring an updated version of DMFAS. This would be contingent on the receipt of appropriate financing from donors and is also dependent on an assessment by a mission from UNCTAD. In addition to DMFAS, UNCTAD would also provide training to the staff of the $\mathrm{BRH}$ and the MEF. The use of an appropriate software and adequate training will be critical for improving debt management.

The following debt service procedures are typically followed. Every month, the BRH sends the MEF a statement of all debt service falling due in the following month. At the end of the months, the MEF issues a payment order for the full amount of debt service for the following month. The BRH debits the Treasury account to pay each creditor as debt service falls due. The BRH cannot legally pay a creditor without having information about the associated disbursement.

The BRH produces monthly, quarterly and annual reports which contain data on external debt. These reports cover the transactions (disbursements and payments) as well as the stock of debt and the accumulation of arrears. The reports are disseminated throughout the Central Bank and MEF. This allows the authorities to integrate the relevant information into the macroeconomic framework. The data are available to the public upon request within one month after the reference period, and are subsequently published with some additional delay.

Looking ahead, Haiti needs to further strengthen its debt management capacity by:

(i) clarifying by law the debt management responsibility of the BRH and the MEF;

(ii) improving information sharing, including frequent debt reconciliation exercises, between the BRH and the MEF; (iii) shortening the procedures for debt service payments;

(iv) improving the tracking of disbursements; (v) acquiring a modern debt reporting system;

(vi) training of staff; and (vii) improving the capacity to produce debt sustainability analyses. 